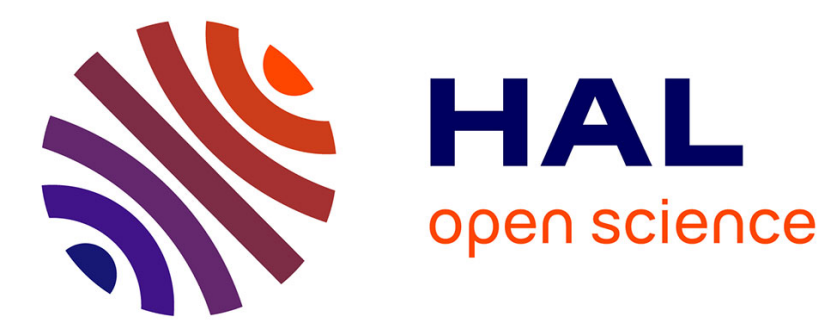

\title{
Neoproterozoic plate tectonic process and Phanerozoic geodynamic evolution of the South China Block
}

\author{
Liangshu Shu, Jinlong Yao, Bo Wang, Michel Faure, Jacques Charvet, Yan
}

Chen

\section{To cite this version:}

Liangshu Shu, Jinlong Yao, Bo Wang, Michel Faure, Jacques Charvet, et al.. Neoproterozoic plate tectonic process and Phanerozoic geodynamic evolution of the South China Block. Earth-Science Reviews, 2021, pp.103596. 10.1016/j.earscirev.2021.103596 . insu-03169133

\section{HAL Id: insu-03169133 \\ https://hal-insu.archives-ouvertes.fr/insu-03169133}

Submitted on 15 Mar 2021

HAL is a multi-disciplinary open access archive for the deposit and dissemination of scientific research documents, whether they are published or not. The documents may come from teaching and research institutions in France or abroad, or from public or private research centers.
L'archive ouverte pluridisciplinaire HAL, est destinée au dépôt et à la diffusion de documents scientifiques de niveau recherche, publiés ou non, émanant des établissements d'enseignement et de recherche français ou étrangers, des laboratoires publics ou privés. 


\section{Journal Pre-proof}

Neoproterozoic plate tectonic process and Phanerozoic geodynamic evolution of the South China Block

Liangshu Shu, Jinlong Yao, Bo Wang, Michel Faure, Jacques Charvet, Yan Chen

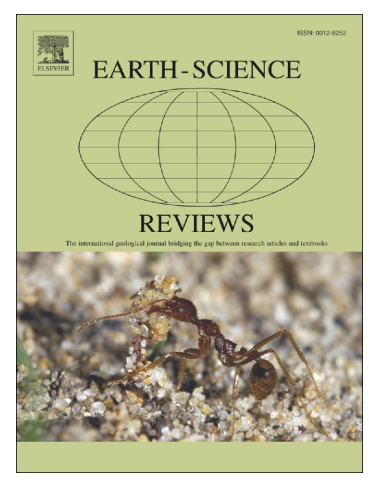

PII: $\quad$ S0012-8252(21)00096-9

DOI: $\quad$ https://doi.org/10.1016/j.earscirev.2021.103596

Reference: $\quad$ EARTH 103596

To appear in: $\quad$ Earth-Science Reviews

Received date: $\quad 29$ September 2020

Revised date: $\quad 8$ March 2021

Accepted date: $\quad 9$ March 2021

Please cite this article as: L. Shu, J. Yao, B. Wang, et al., Neoproterozoic plate tectonic process and Phanerozoic geodynamic evolution of the South China Block, Earth-Science Reviews (2021), https://doi.org/10.1016/j.earscirev.2021.103596

This is a PDF file of an article that has undergone enhancements after acceptance, such as the addition of a cover page and metadata, and formatting for readability, but it is not yet the definitive version of record. This version will undergo additional copyediting, typesetting and review before it is published in its final form, but we are providing this version to give early visibility of the article. Please note that, during the production process, errors may be discovered which could affect the content, and all legal disclaimers that apply to the journal pertain.

(C) 2021 Published by Elsevier. 


\section{Neoproterozoic plate tectonic process and Phanerozoic geodynamic evolution of}

\section{the South China Block}

Liangshu Shu ${ }^{\mathrm{a}, *}$ lsshu@nju.edu.cn, Jinlong Yao ${ }^{\mathrm{b}, *}$ yaojinlong@nwu.edu.cn, Bo Wang ${ }^{\mathrm{a}}$, Michel Faure ${ }^{\mathrm{c}}$, Jacques Charvet ${ }^{\mathrm{c}}$, Yan Chen $^{\mathrm{c}}$

${ }^{a}$ State Key Laboratory for Mineral Deposits Research, Nanjing University Institute of Continental Dynamics, Nanjing 210093, China

${ }^{\mathrm{b}}$ State Key Laboratory of Continental Dynamics, Department of Geology, Northwest University, Xi'an 710069, China

'Université d'Orléans, CNRS, BRGM, ISTO, UMR 7327, F-45 071, Orléans, France

*Corresponding author.

\section{Abstract}

The South China Block is situated in the Eatern Asian margin. Since the Neoproterozoic, its tectonic evolutio. vas constrained by successive consumption-closure processes of thr Pa eo-vouth China, Proto-Tethys, Paleo-Tethys, and Paleo-Pacific oceans. Studier sugges that this block was initially formed by the Neoproterozoic assembly of ne Yangtze and Cathaysia blocks following the subduction-accretion of the Paleu South China Ocean. Then after, it experienced three tectonic-magmatic events in .he Phanerozoic. Among these events, the Late Mesozoic tectonism-magmatism as inked with the consumption of the Paleo-Pacific Ocean, while the Silurian a. 1 Early to Middle Triassic events took place in intracontinental settings that were related to far-field effects of the closure of the remote Proto-Tethys and Paleo-Tethys oceans, respectively. The subduction-accretion of the Paleo-South China Ocean, and collision at 980-820 Ma between the Yangtze and Cathaysia blocks formed the Jiangnan Orogenic Belt and the Proto-South China Continent, followed by a rifting tectonics and bimodal volcanism at 810-760 Ma. From 760 Ma to $460 \mathrm{Ma}$, the South China Block was situated under shore, shallow sea to slope depositional environments. During Late Ordovician to Early Devonian (460-400 Ma), an intracontinental orogeny occurred mainly in the Cathaysia Block as a response to the 
closure of the Proto-Tethys Ocean. Shortly afterwards, this block underwent a stable carbonate deposition during Early Devonian- Middle Triassic (400-230 Ma) and was thus under a shore or shallow sea environment. In the Middle-Late Triassic (240-220 Ma), the South China Block was affected by the closure of the Paleo-Tethys Ocean, intracontinental deformation and S-type granitic magmatism. During the Cretaceous, a multi-stage basin-and-range framework occurred in the western shore of the Paleo-Pacific Plate.

\section{Keywords}

Neoproterozoic Paleo-South China Ocean; Proto-Tett vs C cean; Paleo-Tethys Ocean; Paleo-Pacific Ocean; subduction and accretion; $f_{n-1}$ eld effects of plate collision; South China Block.

\section{Introduction}

The South China Block is lo ated in the western margin of the Pacific Plate and consists of the Yangtze and Catl ar s. blocks and the Jiangnan Orogenic Belt (Fig. 1). Comprehensive analyses or the available tectonic and magmatic data, along with sedimentary structures fro $\urcorner$ the Jiangnan Orogenic Belt and Cathaysia Block, suggest that the evolution o $\mathrm{m}$ ? south China Block was constrained and affected by the Paleo-South China, $\mathrm{r}$ : oto-Tethys, Paleo-Tethys and Paleo-Pacific oceans (Gilder et al., 1991,1996; Ren JS, 2001; Ren and Chen, 1989; Ren and Li, 2016; Ren JS et al., 1998; Li XH et al., 1994; Charvet et al., 1996; Li ZX et al., 1999, 2008; Xu ZQ et al., 2010; $\mathrm{Xu}$ and Zhang, 2013; Faure et al., 2009, 2016a, b; Wang YJ et al., 2010, 2013).

The Paleo-South China Ocean is a NE-trending Neoproterozoic tectonic unit separating the Yangtze and Cathaysia continental blocks and was evidenced by the ophiolite suite extending $1500 \mathrm{~km}$ and ranging in age from $980 \mathrm{Ma}$ to $820 \mathrm{Ma}$ (Guo LZ et al., 1989; Shu LS et al., 1994, 1995, 2014; Wang XL et al., 2006; Yao JL et al., 2014; Zhang GW et al., 2013; Dong YP et al., 2017). The Proto-Tethys Ocean existed 
from the latest Ediacaran to the Carboniferous (550-330 Ma). It formed when Laurentia, Baltica, and Siberia drifted away from each other. This ocean was bordered by the Kazakhstan microcontinent and Panthalassic Ocean to the north, by Siberia to the west, and by Gondwana to the east. Since the Late Silurian, the northward drift of North China and South China blocks away from Gondwana, and subsequent collision between the North China and Siberia-Kazakhstan in the Carboniferous resulted in the closure of the Proto-Tethys Ocean (Stampfli and Borel, 2002; Zhao GC et al., 2018). The Paleo-Tethys Ocean was a precursor to the Neo-Teth. yc Ocean and was located between Gondwana and the Hun super-terranes (includin ; A norica-Iberia in Europe and East-Central Asia). It opened as the Proto-Tethy: Oc zan subducted under these terranes and closed at about $290-180 \mathrm{Ma}$ as $\mathrm{t}^{\mathrm{r}}=\mathrm{C}: \mathrm{mmerian}$ terranes rifted from Gondwana landmasses to form the Neo-Tethys Oze ${ }^{n}{ }^{n}$ at $~ 250 \mathrm{Ma}$ (Stampfli and Borel, 2002; Keppie, 2015; Huang BC et al., 2018! T e Paleo-Pacific Plate, also known as the Izanagi or Kula Plate, was an $r$ cea lic plate existed during the Late Mesozoic. From the Jurassic to Cretaceou with the expanding of the Pacific Plate and the closure of the Okhotsk Ocean t $\cong$ Paleo-Pacific Plate subducted northwestwards beneath the Eurasian contin` ${ }^{n}$. Intil the latest Mesozoic the Izanagi-Pacific Ridge subducted and the Palec Panific Plate totally submerged beneath the Eurasian and North American cont'...n nts, Lapierre et al., 1997).

In the middle 1 oproterozoic, the South China Block was initially formed by the subduction-accretion of the Paleo-South China Ocean and the convergent margin successions between the Yangtze and Cathaysia blocks, but with largely varied timing of the final assembly (Xu B et al., 1992; Shu and Charvet, 1996; Li XH et al., 2003, 2009; Wang XL et al., 2006; Zhao and Cawood, 2012; Yao JL et al., 2014, 2016, 2019a). Shortly after, a within-plate extensional event occurred and formed the rifting magmatic and sedimentary sequences dated at 850-760 Ma in South China (Wang and Li, 2003; Li WX et al., 2005; Shu LS et al., 2011). This rifting magmatism ceased at some time in the Late Tonian and the South China Block was in a stable depositional 
environment since then (Shu LS, 2012). The Cryogenian to Early Paleozoic stratigraphic sequences and fossil features in the South China Block are comparable to those of the Tarim Block (Zhou and Deng, 1996), and detrital zircon U-Pb geochronological results suggest that the South China Block was once adjacent to Northwest Australia, Tarim, Eastern India and East Antarctica in the Neoproterozoic (Yu JH et al., 2008; Xiang and Shu, 2010; Yao JL et al., 2011). In addition, paleomagnetic results show that the South China Block was a member of the Rodinia supercontinent (Yang ZY et al., 2004; Li ZX et al., 2004, 'n08; Han ZR et al., 2015; Jing XQ et al., 2015; Niu JW et al., 2016).

In the Phanerozoic time, the South China Block exp rienced multiple stages of extensive tectono-magmatism, including the witr-a the Early Paleozoic and Early -Middle Triassic tectonic and magmatic everts or Indochina event) which are correlated with the evolution of the $\mathrm{l}$ "sto Tethys and Paleo-Tethys oceans, respectively (Li ZX et al., 2010; War \& Y J et dl., 2010; Charvet et al., 2010; Shu LS et al., 2014, 2015, 2018; Zhao et al., 2018), along with the Early Mesozoic tectono-magmatic event generrie'^ hy the subduction of the Paleo-Pacific Ocean (Zhou XM et al., 2006; Shı LS et al., 2004; Li JH et al., 2016). However, an Appalachian-style multi-t?rra`e Wilson cycle model has also been hotly discussed for the Early Paleozoic aª' Liaı $_{\text {a }}$ Mesozoic orogenic events in South China (Lin SF et al., 2018; Shu et al., ¿רlø; Faure et al., 2018a). These Phanerozoic events strongly reworked the Precambrian basement of the South China Block and also the traces of earlier orogenic events, leading to a less well constrained overall tectonic and paleogeographic evolution of the South China Block.

With the development of high quality geochemical and dating technologies, increasing new results were documented (Wang YJ et al., 2010, 2014; Zhao GC, 2015; Li JH et al., 2016; Yao JL et al., 2019a). In spite of the significant advances, controversies still exist on some major issues related to the pre-Jurassic geological features of the South China Block, including the western continuation of the 
Neoproterozoic suture zone, the formation ages of the Jiangnan Orogenic Belt and Proto-South China Continent, the nature of the basement of the Cathaysia Block and driving forces of the intracontinental tectono-magmatic events, as well as the genesis of the Late Mesozoic South China basin-and-range tectonics (Zhou XM et al., 2006; Li XH et al., 2003, 2009; Faure et al., 2009; Li and Li, 2007; Yan DP et al., 2002; Charvet et al., 2010; Wang and Shu, 2012).

This paper aims to analyze the available field observations and results, to discuss controversial issues, to draw further attention and to $\mathrm{r}$ romote understanding on fundamental geology of the South China Block.

\section{Tectonic setting}

\subsection{Relics of the Paleo-South China Ocean}

The NE- to ENE-extending Shaoxirg- Jirgxiang-Longsheng fault is a suture zone formed in the Neoproterozoic alc ag the southeastern margin of the Jiangnan Orogenic Belt in the SE Yangtze Block (Fig. 1, 2). Ophiolitic mélanges occur along this suture zone, mainly compe se $\mathfrak{d}$ of various-sized lenses of basalt, chert, marble, turbidite and ultramafic-mafi. rocks dated at 980-840 Ma (Li XH et al., 1994; Shu LS et al., 1994, 2015, 201; : iao JL et al., 2019), which were derived from the Paleo-South China C eia. ic crust.

Meters to deca neters-scale exotic blocks of ultramafic-mafic rocks dated at

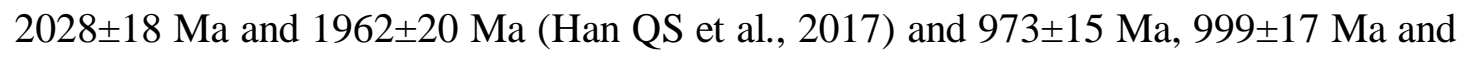
1002 \pm 19 Ma (Deng H et al., 2017) are scatteredly distributed near the Yichang City of the northern Yangtze Block (Fig. 2), and are inferred as relics of the Paleoproterozoic and Early Neoproterozoic ophiolitic mélanges (Han QS et al., 2017; Deng H et al., 2017), symbolizing the northern suture of the Paleo-South China Ocean. The detrital zircons from sandstones of the Cryogenian Liantuo Formation and Nantuo tillite layers in the northern Yangtze Block also yielded similar U-Pb ages as mentioned above (Gao S et al., 2011; Zhao GC et al., 2012). 


\subsection{The Yangtze Block}

The Yangtze Block is mostly covered by Mesozoic-Cenozoic sediments and its margins mainly consist of Neoproterozoic magmatic rocks and sandy-muddy slates and phyllites. The oldest rocks were dated at ca. 3.5-3.0 Ga by zircon U-Pb dating on orthogneiss and amphibole-schist (Gao and Zhang, 1990; Qiu YM et al., 2000; Zhang SB et al., 2006; Wu YB et al., 2009), whereas Late Archean rocks are limitedly exposed in the southwestern Yangtze Block, forming an ancient continental core. Detrital zircon ages from the southeastern Yangtze Bisk indicate that the metamorphosed clastic rocks were deposited at some time ríter 1.0 Ga (Wang XL et al., 2007, 2014; Yao JL et al., 2013).

During 980-860 Ma, the Paleo-South C: ina oceanic lithosphere subducted northwestwards beneath the Yangtze Block $\ldots 1$ f formed the Neoproterozoic Jiangnan trench-arc system of 80-200 km in width a. 'd $1500 \mathrm{~km}$ in length (Xu B et al., 1992; Li XH et al., 2009; Shu LS et al., 199,, 2006; Wang XL et al., 2006; Zhang YZ and Wang YJ, 2016; Yao JL et al., 2014 $`$. This trench-arc system was overprinted by the Yangtze-Cathaysia collision d ${ }^{\text {tred }}$ a* ca. 860-820 Ma (Shu LS et al., 1994, 2019; Shu and Charvet, 1996; Wang $\mathrm{L}$ c al., 2006; 2012; Zhao JH et al., 2013; Yao JL et al., 2016, 2019a; Yan CL è al., :021), forming the Proto-South China Continent (Shu LS et al., 2020), wh ich wa unconformably covered by an Upper Tonian terrigenous molasse sequence.

An intracontinental rifting within the Proto-South China Continent took place during 810-760 Ma, generating mafic dyke swarms and intracontinental rifting basins that were filled by molasses and bimodal volcanic rocks. According to dating data of bimodal magmatic rocks in both the eastern Jiangnan and eastern Cathaysia segments, the initial rifting likely happened at ca. $850 \mathrm{Ma}$ (Li WX et al., 2005; Li XH et al., 2008; Shu LS et al., 2011). 


\subsection{The Cathaysia Block}

\subsubsection{Age of the Cathaysia basement}

The Cathaysia Block is located to the southeast of the Shaoxing-Pingxiang-Longsheng fault (Fig. 2). This block consists of Paleoproterozoic basement (Yu JH et al., 2009) and Neoproterozoic to Early Paleozoic sedimentary covers. Recent studies suggest that the age of the basement in the Cathaysia Block is older than those of the Jiangnan Orogenic Belt and the patterns of deformation are much more complicated. More than 2000 detrital zircon agc. from Ordovician and Devonian sandstones were obtained and can be divided $t_{\ldots}=$ five groups (Xiang and Shu, 2010; Yao JL et al., 2011; Yan CL et al., 2015). The irrst one, 2.56-2.38 Ga (peak at $2.46 \mathrm{Ga}$ ), represents the formation time of glo' $1 \mathrm{cc}$ ntinental nucleus. These zircons are mostly euhedral, indicating a possible $\Perp$ hean basement beneath the Cathaysia Block. The second one, 1.93-1.52 Ga ( $1.9 k$ at $1.8 \mathrm{Ga}$ ), is likely derived from the granitic plutons and amphibolites in $\_$, northern Wuyi terrane, corresponding to the Columbia supercontinent cycle. Th third group, 1.3-0.9 Ga (peak at 0.97 Ga), is indicative of assembly of the $\mathrm{D}_{\mathrm{od}} \boldsymbol{n}$ : a supercontinent, and the related magmatic rocks are sporadically exposed in the Wuyi, Nanling and Yunkai terranes (Fig. 2; Wang YJ et al., 2014). The fourth on:, $0.85-0.73 \mathrm{Ga}$, corresponds to the breakup of Rodinia. The Last group ?.6 २-0.;5 Ga (peak at ca. $0.65 \mathrm{Ma}$ ) records a magmatic event, contemporaneous $v^{\text {'it', }}$ the Pan-African orogeny, which was formed by the assembly of the west and east Gondwana, but no magmatic rock of this age was reported from the whole South China Block. The Late Neoproterozoic age population therefore indicates that the South China Block was a member of the Gondwana Continent, with the upper part of the upper Proterozoic-lower Paleozoic sediments in the block sourced from the interior of Gondwana (Yao JL et al., 2011; Xu YJ et al., 2014; Zhao GC et al., 2018; Cawood et al., 2018). This argument is also supported by recent paleomagnetic data (Han ZR et al., 2015).

Several sub-euhedral detrital zircon grains from Proterozoic and Paleozoic 
meta-sandstones and migmatites in Cathaysia yielded SHRIMP U-Pb ages of 4.1-3.8 Ga (Xu XS et al., 2005; Xiang and Shu, 2010; Yao JL et al., 2011; Xing GF et al., 2014), but coeval magmatic rocks have not been reported. The oldest magmatic rocks are scatteredly exposed in the northern Wuyi terrane (Fig. 2). Twelve samples of granite, amphibolite and migmatite were dated at 1890-1740 Ma(Li XH, 1998; Yu JH et al., 2009). These rocks are inferred to be reliable arguments for the Cathaysia continental core that may extend westwards to the Nanling and Yunkai terranes (Shu LS et al., 2020).

\subsubsection{Geological history of the Cathaysia Block}

Middle Proterozoic rocks are rare in the Cathay ia 1 lock, the Mesoproterozoic setting is therefore unclear. The lower part of upr $=-$ sterozoic metamorphic muddy and sandy rocks with interlayers of marble and meta rhyolitic rocks occur in the Wuyi, Nanling and Yunkai terranes and are asso $i$ te 1 with orthogneiss and meta-gabbro dated at ca. 980-910 Ma (Shu LS e al 2008a; Wang YJ et al., 2012a, 2014). The amphibolite, dolerite and orthogneiss oucur in the Wuyi and Yunkai terranes and

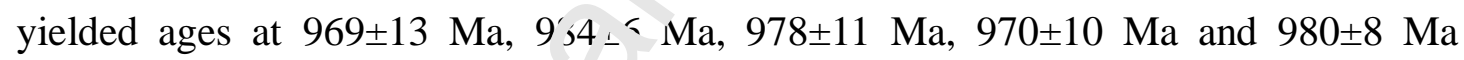
(Wang YJ et al., 2012a). Gr eissiz granite and meta-rhyolite in the Nanling terrane yielded zircon U-Pb ages ot $296 \pm 29 \mathrm{Ma}$ (Liu BX et al. 2001) and 972 $\pm 8 \mathrm{Ma}$ (Shu LS et al., 2008a), resper.aly. In addition, several plutons of gneissic granitoids show geochemical finge ${ }_{\mathbf{r}}{ }^{\text {rints }}$ of arc and back-arc settings. Given their ages and compositional characteristics, these plutons were formed in two stages: ca. $965 \mathrm{Ma}$ (982 $\pm 27 \mathrm{Ma}, 963 \pm 11 \mathrm{Ma}, 954 \pm 14 \mathrm{Ma})$ and ca. $915 \mathrm{Ma}(916 \pm 6 \mathrm{Ma}$ and 909 $\pm 10 \mathrm{Ma}$; Wang YJ et al., 2014), corresponding to the magmatic arc age and the closure time of back-arc basin, respectively. These magmatic rocks indicate a Neoproterozoic subduction and accretion process, leading to the westward expansion of Cathaysia from the Wuyi continental core to the Nanling and Yunkai domains.

The sedimentary cover on the top of the aforementioned metamorphic rocks is composed of terrigenous rocks intercalated with carbonate and carbonaceous rocks, 
ranging from the Upper Tonian (referred to as the Banxi Group, or Nanhua System in Chinese literature) to Upper Ordovician strata (at ca. 800-460 Ma). The Late Tonian mantle-derived mafic rocks (gabbro and basalt) along the Zhenghe-Dapu fault zone (Fig. 2) display geochemical characteristics of continental rift (Li WX et al., 2005). Minor basalt, diabase and gabbro also occur in the southwestern Yunkai terrane and yielded zircon U-Pb ages of ca. 850-780 Ma (Wang YJ et al., 2010). These magmatic rocks show geochemical signatures that are comparable to within-plate basalt, therefore, implying an extensional event during ca. 850-7£ $\mathrm{Ma}$ (Late Tonian) which was related to the generation of the Late Tonian rifting ba ins.

The South China Block was situated in a stable lepc sitional environment at ca. 750-460 Ma, with little magmatic activity. Moreo ${ }^{\cdots *}$ a'though ages ranging from 650 Ma to $500 \mathrm{Ma}$ were obtained from detrital zirco's "ithin pre-Devonian clastic rocks in Cathaysia, there is no geological and $\mathrm{n}, 5 \mathrm{~m}$ atic trace for the Pan-African event (Xiang and Shu, 2010; Yao JL et al. 20 1), and the reasonable interpretation of these ages requires more work in future

\subsection{Multi-terrane frameworl in tre Paleo-South China Ocean}

Studies suggest that . 'm rous tectono-stratigraphic terranes with various origins and distinct geologic $\ldots$ i istury were distributed in the Paleo-South China Ocean in the Neoproterozoic. Fiw Neoproterozoic tectono-stratigraphic terranes (Fig. 2) were identified in the NW part of the Paleo-South China Ocean domain (now to the SE margin of the Yangtze Block). They are the oceanic crustal-type Huaiyu terrane, the continental crustal-affinity Zhanggong and northern Hunan terranes, and the arc-type Jiuling and northern Guangxi terranes (Guo LZ et al., 2000; Shu LS et al., 1995, 2019; Xu B et al., 1992; Charvet et al., 1996).

The Huaiyu terrane (Fig. 2) is composed of Neoproterozoic ophiolitic mélange, volcanic and turbidite sequences, belonging to an intraoceanic back-arc marginal sea with a tectonic affinity of oceanic crust, whereas the Zhanggong and northern Hunan 
terranes (Fig. 2) mainly consist of quartz-sandstone, sandstone and mudstone, showing continental crustal affinities (Shu LS et al., 1995, 2019; Wang XL et al., 2012). The Jiuling and northern Guangxi terranes (Fig. 2) incorporate Neoproterozoic ophiolitic mélange and 870-840 Ma basaltic-andesitic rocks with positive $\varepsilon \mathrm{Hf}(\mathrm{t})$ values (Yao JL et al., 2016; Sun JJ et al., 2017) which were correlated to trench-arc setting (Charvet et al., 1996; Zhou MF et al., 2002; Wang XL et al., 2007; Yao JL et al., 2014a, 2016a; Sun JJ et al., 2017).

These five terranes are bounded by major f, vlt zones, namely, the Dongxiang-Dexing-Shexian fault zone between the Zhar ggc ng and Huaiyu terranes, the northern Ganjiang fault zone between the Zhan gon $;$ and Jiuling terranes, the Miluo-Xiangtan fault zone between the Jiuling ard nc thern Hunan terranes, and the Jishou-Longsheng fault zone between the northe, Hunan and northern Guangxi terranes (Fig. 2; Shu LS et al., 1995, 2000, 27.9. The Huaiyu, Zhanggong and Jiuling terranes constitute the eastern Jiangr an Jroyenic Belt while the northern Hunan and northern Guangxi terranes form the weste.n Jiangnan Orogenic Belt.

Three tectono-stratigraphic ie' ${ }^{\prime n}$ es have been recognized in the SE part of the Paleo-South China Ocean d man: (now to the NW margin of the Cathaysia Block),

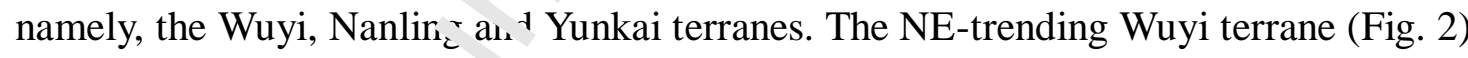
is the oldest one am n liem, and consists of gneiss, migmatite, amphibole schist, and meta-granitoid $v^{-i t h}$ protolith zircon U-Pb ages around $1800 \mathrm{Ma}(\mathrm{Li} \mathrm{XH}, 1998$; Yu JH et al., 2009). These lower Proterozoic strata are overlain by middle and upper Proterozoic sequences of meta-arkose, phyllite, slate and interlayers of meta-tuffaceous rocks. The boundary between the Wuyi and Nanling terranes (Fig. 2) is marked by the sub-S-N-trending southern Ganjiang fault zone.

The sub-E-W-trending Nanling terrane is composed of the upper Proterozoic sandy-muddy slate and phyllite intercalated with meta-rhyolite and meta-rhyolitic wacke dated at $972 \pm 8 \mathrm{Ma}$ (SHRIMP U-Pb age), showing characteristics of arc magmatism (Shu LS et al., 2008a). The NE-trending Yunkai terrane (Fig. 2), located 
in the southwestern segment of the Cathaysia Block, mainly comprises sandy-muddy slate, sericite-chlorite phyllite, biotite schist, S-type granite or orthogneiss, along with minor meta-basalt and gabbroic rocks. These rock suites are dated at 984-909 Ma (Wang YJ et al., 2014). The boundary between the Nanling and Yunkai terranes is unclear because it is completely covered by younger formations.

\section{Proterozoic plate tectonics}

\subsection{Subduction and closure of the Paleo-South China Oc in}

3.1.1 Ophiolitic mélange (980-860 Ma) To the so' un as margin of the Yangtze Block, two Early Neoproterozoic ophiolitic mélang zones were identified along the Shaoxing-Pingxiang-Longsheng and Dongxiang-_ex.ng-Shexian zones (Fig. 1; Guo LZ et al., 1989; Shu LS et al., 1995, 2019; Z aa' ${ }^{\prime}$ SB et al., 2012; Yao JL et al., 2016a, 2019a; Sun ZM et al., 2018). The forr.." r ulted from the closure of the Paleo-South China Ocean, following a collision bc.veen the Yangtze and Cathaysia blocks, and the latter was formed by the mcistion of the Huaiyu and Zhanggong terranes following the closure of the 'Mlaiyu back-arc marginal sea (Shu LS et al., 2019). Ultramafic-mafic blocks a e well preserved within both ophiolitic mélange zones, especially along the Dungxiang-Dexing-Shexian suture zone. The main rock types include ultramafic ' $\mathrm{o}^{1}{ }^{1} \mathrm{c}$, pyroxenite, harzburgite, lherzolite), mafic rocks (cumulative gabbro, pillow lu.d, diabase, meta-basalt), chert, red chert, marble and metamorphosed muddy-sandy flysches. Ophiolitic anorthosite and plagio-granite have also been reported in the Shexian (Shu LS et al., 2019) and Dexing (Li WX et al., 2008) segments. In the field, the ophiolites have been involved into a disrupted and disordered mélange. Most of the ophiolitic rocks have been deformed to form elongated blocks lying parallel to the shear foliation.

More than 200 outcrops of ophiolitic mélanges were reported along the Dongxiang-Dexing-Shexian fault zone, whereas only 20 sites are distributed along the Shaoxing-Pingxiang-Longsheng fault zone (Shu LS et al., 1995, 2020). Previous 
geochemical results on the ophiolitic rocks suggest that the mafic-ultramafic members of the ophiolite have E-MORB fingerprints and the ophiolite was formed at around $900 \mathrm{Ma}$ (Table S1). For example, plagiogranite of Dexing at 968 $\pm 23 \mathrm{Ma}$ (Li XH et al., 1994) or $970 \pm 21 \mathrm{Ma}$ (Gao J et al., 2009), gabbro of Dexing at $930 \pm 34 \mathrm{Ma}$ (Xu and Qiao, 1989), mafic rocks of SW Dexing at 935 \pm 10 Ma (Chen JF et al., 1991) and mafic rocks of Shexian at $874 \pm 10$ Ma and $857 \pm 5$ Ma (Cui X et al. 2017; Shu LS et al., 2019) (Figs. 3 and 4; Table S1).

\subsubsection{Magmatic arc (910-840 Ma)}

Arc-type magmatic rocks consist of basalt, andesite gaı bro dated at ca. $910 \mathrm{Ma}$ and I-type granite dated at 880-840 Ma (Fig. 4; Zhan. St et al., 2012; Yao JL et al.,


distributed in the Jiangnan Orogenic Belt (Guo I Z c al., 1989; Shu et al., 1994, 1996, 2000; Wang XL et al., 2007, 2012; Yao JJ . ‘ al , 2016b; Zhang and Wang, 2019). In addition, arc type hornblende-bearir 6 g anilus dated at $913 \pm 15 \mathrm{Ma}$ and $905 \pm 14 \mathrm{Ma}$


2009) and $879 \pm 10 \mathrm{Ma}$ (Yao JL e . a.., 2014c), respectively, are widely developed in the Huaiyu terrane. In the Lon vou area along the Shaoxing-Pingxiang fault zone, the Neoproterozoic magmat:- Licons from mafic rocks dated at $879 \pm 11$ Ma were reworked and replace: hy metamorphic zircons dated at around $430 \mathrm{Ma}$ (Wang JQ et al., 2017). The arc- pe granitic plutons in Shexian of the Huaiyu terrane emplaced during 848-843 Ma (Shu LS et al., 2019). The andesite, basaltic andesite and dacite of the western Jiuling terrane yielded $\mathrm{U}-\mathrm{Pb}$ ages of $837 \pm 4 \mathrm{Ma}$ and $835 \pm 7 \mathrm{Ma}$, respectively (Zhang YZ and Wang YJ, 2019). Furthermore, the continental arc-type gabbros in the Longsheng of the northern Guangxi terrane yielded crystalline ages of 855 \pm 5 Ma and 867 \pm 10 Ma (Yao JL et al., 2014a, 2016a; Figs. 3 and 4; Table S1).

In the Cathaysia Block, only a few outcrops of gabbro, orthogneiss and meta-rhyolite dated at 980-910 Ma (Figs. 3 and 4) are distributed and were considered as evidence for a Neoproterozoic magmatic arc (Shu LS et al., 2008a; Wang YJ et al., 
2014; Zhang AM et al., 2012).

\subsubsection{The HP/LT metamorphism}

Several exposures of high-pressure (HP) and low-temperature (LT) metamorphic rocks, such as glaucophane-jadeite schist, were reported along the Dexing-Shexian fault zone in the eastern Jiangnan Orogenic Belt (Shu LS et al., 1994; Zhou and Zhou, 1996). The largest relics of blueschist crops out in the Dexing ophiolitic mélange and is only 2-3 meters wide and 20-30 meters long. From the glaucophane-jadeite schist, metamorphic conditions were estimated at $0.9-1.3 \mathrm{GPa} \cdot \mathrm{rd} 250-450^{\circ} \mathrm{C}$ (Zhou and Zhou, 1996). The glaucophane grains yielded K-Ar ages of o $\uparrow 4.5 \pm 15$ and $867.5 \pm 13.5$ Ma (Fig. 3), representing the timing of initial closing (f th Paleo-South China Ocean and the Huaiyu marginal sea (Shu LS et al. 1995, n̊1s;

\subsection{Collision and assembly of the Yangtze 'in ' Cathaysia blocks}

\subsubsection{Ductile shear zones}

The closure of the Paleo-So rth Chira Ocean caused the collision of the Yangtze and Cathaysia blocks and regic na-nale ductile deformation. The above-mentioned ophiolitic mélange zones w`e auctilely deformed and then unconformably covered by brittlely deformed $\mathrm{Col}_{\varepsilon}^{\sim} \mathrm{lo}_{\mathrm{L}}$ erate and quartz-sandstone of the Upper Tonian strata. The Shaoxing-Pingx ${ }^{i} \mu_{c}^{-}$suear zone is $10-30 \mathrm{~km}$ wide, extending E-W for more than $800 \mathrm{~km}$, and the Doı rxiang-Dexing-Shexian shear zone is 5-10 km wide and extends along a NE strike for about $250 \mathrm{~km}$. Within both shear zones, felsic, granitic and phyllitic mylonites show clear stretching lineation, shearing foliation and various asymmetric kinematic indicators, indicating an early top-to-the-SE thrusting and a late sinistral strike-slip shearing, corresponding to a geodynamic evolution of oblique sudduction-collision (Shu LS et al., 1995; Shu and Charvet, 1996).

\subsubsection{Regional greenschist facies metamorphism}

Coeval with the ductile shearing, the amalgamated continent of the Yangtze and Cathaysia blocks, namely, the Proto-South China Continent experienced a regional 
greenschist facies metamorphism, forming large-scale low-grade metamorphic rocks that occupy an area of more than $300,000 \mathrm{~km}^{2}$, including slate, phyllite and meta-volcanic rocks. Meanwhile, middle to high-grade garnet-bearing schist, amphibole schist and orthogneiss also occur along the margins and on the top parts of coeval S-type granites. The U-Pb ages of metamorphic rims of zircon grains were obtained at around $840 \mathrm{Ma}$, which were considered as fingerprints of the middle Neoproterozoic metamorphic timing (Yan CL et al., 2015; Yao JL et al., 2017).

\subsubsection{Collisional S-type granitoids (845-815 Ma)}

More than 15 granite plutons (about 12,000 squar: $\mathrm{kL}$ 's in total) are exposed along the Jiangnan Orogenic Belt. These plutons con ain commonly cordierite,

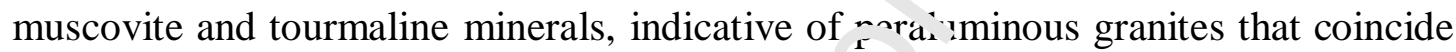
well with their negative $\varepsilon \mathrm{Hf}(\mathrm{t})$ values $(-5$ to -12$)$ ? $\mathrm{fircons}$ and $\mathrm{A} / \mathrm{CNK}$ values of 1.3-1.5, suggesting a partial melting of sup $\because$-c ustal sedimentary rocks, most likely due to crustal thickening caused by $t^{\prime}$ ^e $\mathrm{c}$ sllision of the Cathaysia and Yangtze blocks. These S-type granitic plutons yielded nu.nerous zircon $\mathrm{U}-\mathrm{Pb}$ ages ranging from 845 Ma to $815 \mathrm{Ma}$, with a peak at 6. $\mathrm{Ma}$, and they are covered by the Upper Tonian coarse-grained clastic rocks (F1. 4, Table S1; Li ZX et al., 1999; Zeng W et al., 2005; Zhong YF et al., 211,; Wang XL et al., 2006; Zheng YF et al., 2007; Yao JL et al., 2014a, 2016; War o Vuc al., 2019; Yan CL et al., 2021).

\subsubsection{Regional-scal ?ngular unconformity (820-795 Ma)}

The Upper Tonian (or Nanhua System) coarse-grained clastic rocks were unconformably deposited above the pre-Upper Tonian (or Sibao Group) strata and are widespread in the Jiangnan Orogenic Belt. The youngest detrital zircon population in the Upper Tonian clastic rocks varies between 820 Ma and $795 \mathrm{Ma}$ (Sun JJ et al., 2018; Yan CL et al., 2019), constraining the uplifting, eroding, transportation and accumulation processes at the Late Tonian period. Along the Jiangnan Orogenic Belt, the Neoproterozoic unconformity can be clearly observed in many sites (Fig. 5). However, a contemporaneous unconformity does not exist in the Cathaysia Block 
(Shu LS et al., 2020).

Below the unconformity, the Lower Tonian (or Sibao Group) greenschist facies meta-volcanic and meta-sedimentary sequences have been deformed into tight, disharmonic and asymmetric folds, and above the unconformity, the Upper Tonian (or Nanhua System) consists of undeformed conglomerates and sandstones (Fig. 6) that were occasionally intruded by diabase dykes. The Upper Tonian System is disconformably covered by the Cryogenian tillite layer and Ediacaran to lower Paleozoic neritic sedimentary sequences.

\subsection{Rifting and bimodal magmatism (810-760 Ma)}

Shortly after the assembly of the Yangtze and Ca hay ia blocks, several foreland

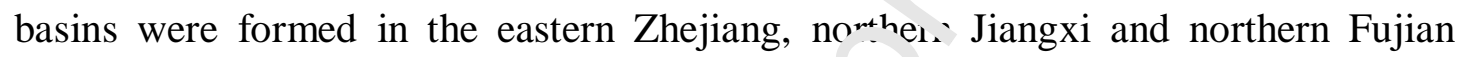

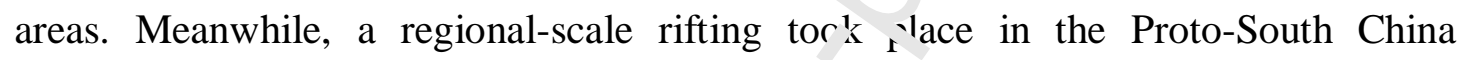
Continent (Gilder et al., 1991). This eve.t is characterized by the formation of sedimentary basins and bimodal igr ¿ou, rocks (gabbro, diabase, basalt, and granite dykes, felsic volcanic rocks) with geouhemical characteristics of continental rift (Gilder et al., 1991) and probabl/ $\mathrm{r}_{\text {_. }}$ ) lted from a mantle plume (Li ZX et al., 1999; Li XH et al., 2003).

The bimodal magmatiss is diachronous in different areas. The initial rifting is dated as early as $25^{\circ} \mathrm{M}$ a in the Cathaysia Block (Li WX et al., 2005; Li XH et al., 2008; Shu LS et al., गU1), whereas the widespread bimodal dyke swarms and rifting basins were formed at 810-760 Ma in the Jiangnan Orogenic Belt, with a peak age of 790 Ma (Li ZX et al., 1999, 2003; Wang XL et al., 2012; Yao JL et al., 2014b; Fig. 4; Table S1).

Many bimodal diabasic and granitic dykes of several meters width and several hundred meters length, often occur in the S-type granite plutons as seen in the eastern and western Jiangnan segments (Fig. 2). In the northern Guangxi terrane, the bimodal volcanic rocks, consisting of vesicular alkaline basalt and rhyolite, occur as interlayers within the Upper Tonian quartz sandstone strata. In the Jiuling terrane, 
zircons from E-W-extending diabase dykes yielded a U-Pb age of $812 \pm 5 \mathrm{Ma}$ (Wang XL et al., 2006), whereas zircons in basalt and rhyolite from the Huaiyu terrane were dated at 794 $\pm 9 \mathrm{Ma}$ and 792 $\pm 5 \mathrm{Ma}$, respectively (Wang and Li, 2003; Li XH et al., 2008). Our field investigations suggest that these bimodal igneous rocks were initially developed along the previous suture zone, namely, the Shaoxing-Pingxiang-Longsheng fault zone (Shu LS et al., 2019). In the Jiuling terrane, this early-middle Neoproterozoic suture zone was rifted into two branches, namely, the Nanchang-Wenjiashi and the Dongxiang-Pingxiang rif ing zones (Fig. 7). A Late Tonian Dongxiang-Pingxiang rifting basin was formed in bet reen these two branches as is inferred from a $100 \mathrm{~m}$ thick meta-spilite layer ( atec at ca. $780 \mathrm{Ma}$ (Shu LS et al.,1995; Charvet et al., 1996). Two extensional recio.s were filled by coarse clastic rocks, bimodal volcanic rocks and associated a"ka.ne basaltic dykes (Li XH et al., 2003). The previous foreland basins wer in olved into this event and became components of the above-mentioned $\mathrm{CW}_{\mathrm{H}}$ depositional regions. A coeval rifting basin and diabasic dykes were also formed in tıe Cathaysia region to the south (Fig. 7).

In addition, tillites and murd andy clastic rocks were deposited and were well preserved in the NE-SW exte 111. western Jiangnan and the N-S extending Kangdian (SW Sichuan) rifting ba: 'ns 'Ren and Chen, 1989; Wang and Li, 2003). Thus, the rifting ended at $\sim 760:{ }^{\prime}$ and then was covered by the Cryogenian tillite layer in both

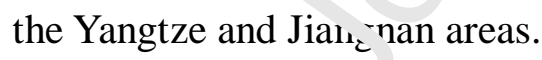

On the basis of the above geological features, a Neoproterozoic lithospheric evolution model for the South China Block is summarized in Fig. 8.

\section{The Ediacaran to Early Paleozoic evolution: influence of the closure of the Proto-Tethys Ocean}

Studies suggest that the Pan-African aged subduction did not obviously affect the South China Block (Yao JL er al., 2011, 2019). From the Ediacaran to Early Paleozoic (760-460 Ma), the sediments from the Jiangnan Orogenic Belt, the Cathaysia Block 
and neighboring areas were deposited in a stable neritic-slope environment (Fig. 9), and no trans-lithosphere fault and oceanic crust were found (Ren and Chen, 1989; Rong JY et al., 2003, 2010, 2018, 2020; Chen X et al., 2012; Rong JY, 2018; Wang Y et al., 2018, 2020a). Neither mappable volcanic lava or volcaniclastic rocks, nor deep-sea sedimentary rocks or turbidite with Bouma sequence were observed from lower Paleozoic strata in both the Jiangnan and Cathaysia regions (Shu LS et al., 2008c, 2014; Shen WZ et al., 2009).

\subsection{Ediacaran - Ordovician stable sedimentation}

Since the Ediacaran, two stable depositional regiols o curred in South China, namely, the Cathaysia one to the south and the Jianı nan one to the north, with the Shaoxing-Pingxiang-Longsheng fault zone in bet $\cdots e_{\mathbf{1}}$. The Ediacaran System in the Cathaysia depositional region mainly consists of $3 \mathrm{a}_{1}{ }^{\mathrm{\gamma}} \mathrm{y}$ and muddy rocks whereas that in the Jiangnan depositional region is con $r$ s $d$ of limestone, dolomite and chert sequence intercalated with sandy-r adc $y$ rucks. The lower Paleozoic sedimentary sequences in the Jiangnan region are also composed of neritic carbonate rocks and chert, whereas neritic-slope sards ine and siltstone with limestone lenses are well developed in the Cathaysia r.gion. The lower Paleozoic strata in the Jiangnan region contain abundant trilobite, ct $\epsilon_{\boldsymbol{r}}$ halopoda, armenoceras, coral and brachiopoda fossils, whereas those in the $\mathrm{r}_{\boldsymbol{u}}{ }^{\mathrm{h}} \mathrm{h}$ a $\mathrm{y}$ sia region are marked by abundant graptolite fossils (Figs. 9 and 10; Rong JY t. Il., 2010, 2018; Chen X et al., 2012; Rong JY 2018). In terms of the Ediacaran to Early Paleozoic sedimentary and paleobiological differences, the Shaoxing-Pingxiang-Qidong-Longsheng fault zone is roughly considered as the boundary between the Jiangnan and the Cathaysia depositional regions whereas gradual sedimentary transition can be still observed in several segments (Chen X et al., 2012; Shu LS et al., 2015, 2019, 2020).

Lithostratigraphic sequences from 9 segments in 7 provinces (Fig. 10) show that both the Jiangnan and Cathaysia depositional regions were situated in a platform-shallow sea depositional environment (Shu LS et al., 2008c, 2014; Shen WZ 
et al., 2009; Wang YJ et al., 2010). The lower Paleozoic siliceous carbonate sequences, 3000-5400m thick, were accumulated in the Jiangnan region (Figs. 9 and 10). The coeval stratigraphic sequences deposited in the Cathaysia depositional region are graptolite-bearing sandy-muddy sequences interlayered with carbonaceous layers and limestone lenses with a thickness of 5600-7000m (Figs. 9 and 10).

Lower Paleozoic clastic sequences are widely distributed in the Wuyi, Nanling and Yunkai terranes. Sedimentary structures and rocks such as ripple mark, mudstone clasts in sandstone, sandstone blocks in mudstone, arkosc and limestone lenses are well preserved, indicative of a neritic to slope depositiona en ironment (Fig. 11).

4.2 The Early Paleozoic tectono-magmatic event $\cdot$ responses to the closure of the Proto-Tethys Ocean

\subsubsection{Paleogeographic differences $r$ ' the Cathaysia and Jiangnan regions since the Late Ordovician}

Since the Late Ordovician ( 4 ? Ma), paleogeographic variations within the South China Block can be ob,creu from sedimentary features (Rong JY et al., 2010). In the Jiangnan deposition ${ }^{1}$ region, the Upper Ordovician to Silurian muddy-sandy sequences were well de alr ped, whereas the whole Cathaysia region has no coeval stratum due to si $\cap_{1_{i}}$ aplifting and erosion. The major Yangtze Block has few outcrops of clastic 1uiks due to the large-scale Quarternary cover. In the E-W-trending sedimentary depression between the Cathaysia and Jiangnan depositional regions, a 4,000-5,000 m-thick Silurian molasse sequence with variable detritus compositions was accumulated, displaying a northward transition from coarse-grained and less rounded clastic rocks in the south to fine-grained ones in the north (Shu LS et al., 2008c, 2014). The thickness of Silurian strata in the depression shows a northward increasing trend from 2,000 $\mathrm{m}$ to $3,000 \mathrm{~m}$, and then to 6,000 m (Fig. 9). Detrital zircon age spectra also indicate a northward transportation of detritus from the provenances in the south ( $\mathrm{Li} \mathrm{HB}$ et al., 2013), consistent with northwestward 
expansion of the Cathaysia Block (Rong JY et al., 2010, 2020; Wang Y et al., 2020).

Fig. 10 also shows an obvious difference in tectonic-sedimentary environment during the Silurian. Deposition in the west Jiangnan and Yunnan areas to the west of Xuefeng Mts. formed a continuous and thick Silurian sequence (Ren JS et al. 1990). In the Xuefeng Mts. (Fig. 2), the thick Silurian clastic sequence was folded and thrusted during the Triassic period (Chu Y et al., 2012a). However, to the southeast of the Xuefeng Mts., Silurian strata in the Cathaysia Block are lacked and an angular unconformity exists between the Devonian and Ordovician strata (Figs. 9 and 10; Wang Y et al., 2020). The Ediacaran-Ordovician strata r ere intensively deformed to form tight folding and thrusting structures. The erod $\mathrm{d}$ a tritus was transported and deposited in the northern and western margins of the Sathaysia Block, forming thick olistostromes (Fig. 10; Rong JY et al., 2003, 201\%).

\subsubsection{Silurian deformation and metamorp ${ }^{\circ}$ sn}

During the Silurian, the Cathar sia Block experienced intensive folding-surface uplift and metamorphism. Asymmetru or recumbent folds are common with maximum shortening up to $67 \%$, I $^{2}$ LS et al. 2008c). Major fold axes display ca. E-W and NE-direction orie tatın, associated with thrust-type and strike-slip-type ductile shear deformatior, an ${ }^{2}$ their ages are dated at ca. 430-390 Ma, coeval with or slightly younger than $\therefore$ puak age of granitic magmatism (Figs. 7 and 12; Wang YJ et al., 2010; Shu LS eı ^l., 2015). Along the fold axial folded zone in the Wuyi terrane, kinematic indicators suggest top-to-the SE shearing on the southeastern side and top-to-the NW shearing on the northwestern side, forming a regional fan-like thrusting structure (Shu LS et al. 2008c; Charvet et al. 2010; Li JH et al., 2016, 2017).

The Early Paleozoic tectonic event strongly reworked the Proterozoic rocks of the Cathaysia Block. All pre-Silurian sandy and muddy rocks were metamorphosed into slates and phyllites, indicating a regional low-grade metamorphism which is dated at $453 \pm 7 \mathrm{Ma}$ (monazite U/Th-Pb chemical dating; Faure et al, 2009) and 433 \pm 1 Ma, 428 \pm 1 Ma to $391 \pm 3 \mathrm{Ma}\left({ }^{40} \mathrm{Ar} /{ }^{39} \mathrm{Ar}\right.$; Shu LS et al., 2015). Thick Middle-Upper 
Devonian molasse beds unconformably cover the aforementioned deformed and metamorphosed Cambrian-Ordovician strata and Silurian plutonic rocks.

Some orthogneiss, granitic gneiss and migmatite with mylonitic foliation and stretching lineation are locally developed around the margins of some Silurian plutons (Shu LS et al., 2008c, 2018; Wang YJ et al., 2010; Zhang GW et al., 2013). Far away from the plutons, only regional lower-greenschist facie slate and phyllite occur, without any high temperature metamorphic rocks. There is also barrowian metamorphism with biotite-garnet-kyanite relics (Zhao ar 1 Cawood, 1999; Faure et al., 2009; Charvet et al., 2010). For example, in some se me ts of the northern Wuyi and southwestern Yunkai terranes, rock assemblage: of schist, granitic gneiss and migmatite are locally observed along the margins of 5 type granitic plutons with ages of 440-420 Ma and disappear in areas away from . ne plutons. Thus, the high-grade metamorphic rocks within the Cathaysia "sc : are related to thermal input from granitic magma in an overall intrar snt nenıal setting (Shu LS et al., 2015, 2018). These observations are incompatible wili models that favor continental collision to generate large-scale high-grade ne. morphic rocks (Lin SF et al., 2018).

In the Jiangnan region, "eitı:r Silurian thrusting-type mylonite was reported nor

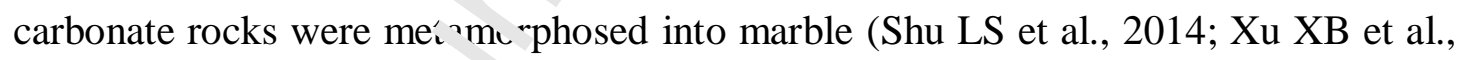
2018). The mylonitic ^ ${ }^{-} \mathrm{s}$ are only observed within several large strike-slip shearing zones (Li JH et al., गU17; Xu XB et al., 2018), no large-scale ductile thrusting was observed. Locally, decameters-scale ductile decollements developed within the Ediacaran strata occur in the northeastern Jiangxi (Shu LS et al., 1995; Faure et al. 2009).

\subsection{Silurian peraluminous granitic plutonism}

As tectono-magmatic responses to the closure of the Proto-Tethys Ocean, the Cathaysia Block underwent widespread folding-faulting, partial melting and granitic magmatism in the Silurian. More than 200 Silurian granitic plutons with total a total area of $20,900 \mathrm{~km}^{2}$ are distributed in an area of 1,200 km long and $800 \mathrm{~km}$ wide, 
covering both the Cathaysia and Jiangnan regions. Granitoids mainly consist of two-mica granite, cordierite-bearing granite and tourmaline-bearing muscovite granite. Negative zircon $\varepsilon \mathrm{Hf}(\mathrm{t})$ values (-5.1 to -12.5$)$ and 1.23-2.43 Ga model ages suggest that these granites were generated by partial melting of Paleo-Mesoproterozoic crustal material without input of mantle-derived melt. Much less coeval I-type granites with lower $\varepsilon \mathrm{Hf}(\mathrm{t})$ values $(-1.4$ to +7.2$)$ only occur occasionally in several areas $\left(<400 \mathrm{~km}^{2}\right.$ namely, $<2 \%$ of total area) in the Cathaysia Block, they were considered as the result of partial melting of mafic rocks in the lower crust (Shu Li et al., 2018). Minor mafic rocks or mafic-intermediate enclaves in the granitoids $\mathrm{r}$ ave also been reported in a few localities and are dated at ca. $450 \mathrm{Ma}$ and ca. $435 \downarrow$ Ta (Fig. 12, Table S2), the former was also interpreted as partial melting $\approx$ a metasomatized subcontinental lithospheric mantle and the latter was formed by $\mathrm{p}^{\mathrm{r}} \mathrm{rtial}$ melting of the mafic crust, both in an intracontinental setting (Zhang $X_{i}^{\prime}-t: 1 ., 2017$ ).

Ductile deformed and middle $" h_{c}{ }^{-h}$-grade metamorphosed rocks can be observed along margins of some plu $\mathrm{n}_{\mathrm{n}}$ in the Wuyi and Nanling terranes of the

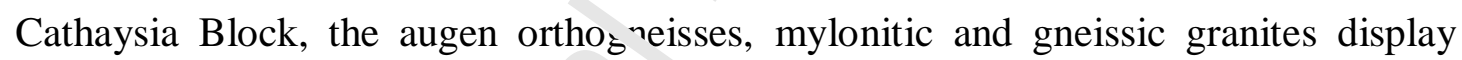
shearing foliation, stretching liner tir $n$ and plentiful asymmetric kinematic indicators including asymmetric feldsr, " poiphyroclasts, augens and S-C shear bands (Faure et al., 2009; Charvet et al., 2u:9; Xu XB et al., 2011; Wang B et al., 2014). Neither mappable lower Palenzo: arc magmatic rocks nor subduction-related accretionary complex were rec $\mathrm{g}_{\mathrm{L}}: \mathbf{}^{\mathrm{d}} \mathrm{d}$ in the Cathaysia or Jiangnan regions. These deformation, metamorphism and scanitic magmatism are inferred to be a far-field behavior of intracontinental responses to the closure of the Proto-Tethys Ocean, which is a coeval ocean between the South China-North Vietnam and the South Vietnam blocks that is called as the Tam Ky-Phuoc Son Ocean (Faure et al., 2018b).

All the undeformed and deformed plutons have similar age ranges without any apparent spatial and temporal evolutionary regularity (Song MJ et al., 2015; Shu LS et al., 2015, 2018). The zircon U-Pb and mica ${ }^{40} \mathrm{Ar} /{ }^{39} \mathrm{Ar}$ ages from 246 samples show that the ages of crystallization of granitoids and diabase (at 460-390 Ma, peak at 440-420 Ma) are comparable with the timing of mylonitic rocks and metamorphic rocks (at 430-390 Ma by ${ }^{40} \mathrm{Ar} /{ }^{39} \mathrm{Ar}$ on muscovite; Fig. 12; Table S2; Zhang Y et al., 
2011; Wang YJ et al., 2012b, 2013b; Shu LS et al., 2014, 2015; Song MJ et al., 2015; Wang B et al., 2014; Zhang XS et al., 2017; Yan CL et al. 2017).

\subsection{Tonian-Early Paleozoic dynamic evolution of the South China Block}

In the Early Neoproterozoic (980-850 Ma), a northwestward (current coordinates) subduction of the Paleo-South China Oceanic plate occurred, forming accretionary complexes and arc magmatic rocks. The final closure of the Paleo-South China Ocean was followed by a collision between the Yangtze and Cathaysia blocks, and the accretion of the aforementioned five terranes along the $x$ "thzastern margin of the Yangtze Block, leading to metamorphism, ductile de or natıon, granitic magmatism dated at 840-820 Ma and formation of the Jiangna.. Orogenic Belt and Proto-South China Continent at 825-800 Ma (Fig. 8C and 1: 1 ). Thereafter, an intracontinental rifting event occurred in the Proto-South $\mathrm{Cr} / \mathrm{n}$. Continent, leading to the formation of the extensional Jiangnan and $\mathrm{Cat}^{r} \mathrm{a}_{\text {s }}$ sia depositional regions. This event was characterized by mantle-derived magm $\mathrm{m}^{+}$ic intrusion and bimodal volcanism dated at 810-760 Ma in the Nanhua rif* ' vasin (Fig. 8D), namely, a part of the initial Proto-Tethys Ocean. From th - 'Teuproterozoic to the Late Ordovician (760-460 Ma), a stable neritic depositionai nlatiorm was developed in the South China Block. In the Cambrian-Ordovician puris $d$, the South China Block became a member of the northern Gondwan. Cin.inent (Fig. 13B) and is characterized by carbonate sequences containing plenty oi rrilobite, brachiopoda and coral fossils in the northern Nanhua sea basin that belongs to the Jiangnan depositional region (NR in Fig. 13B). The coeval graptolite-bearing sandy-muddy sedimentary successions in the southern Nanhua sea basin belongs to the Cathaysia depositional region.

Since the Late Ordovician, the closure of the Early Paleozoic Qinglin Ocean (a branch of the Proto-Tethys Ocean) along the northern margin of the South China Block caused a collisional orogeny along the Shangdan suture zone (Fig. 13C) associated with HP/LT blueschist and UHP eclogite facies metamorphism (Mattauer et al., 1985; Dong YP and Santosh, 2016). To the southeast of the South China Block, 
the subduction of Proto-Tethys Ocean and subsequent collision took place between the South China-North Vietnam-Laos Block and the South Vietnam-Khmer Block along the Tam Ky-Phuoc Son suture (Tran et al., 2014; Gardner CJ et al., 2017; Faure et al., 2018a,b; Wang YJ et al., 2020a) and generated an ophiolite-bearing mélange zone, arc-type granitoids and eclogites dated at 480-450 Ma in the Kontum Massif of Center Vietnam (Nagy et al., 2001; Roger et al., 2007; Nakano et al., 2013; Tran et al., 2014; Faure et al., 2018b). The assemblage of the Indochina Block (IC in Fig. 13C) might have been initiated since the Late Ordovician to Ea $\cdot v$ Silurian and terminated in the Early-Middle Devonian. This was coeval with the int continental folding and thrusting, lower greenschist facies metamorphism, sy 1-tectonic S-type granitic magmatism and migmatization along the Wuyi-Y*nkai domain within the Cathaysia Block (Fig. 13C) (Faure et al., 2018b; Wang YJ at .'., 2020b). Finally, the Cathaysia region evolved into the Early Paleozoic Snc ${ }^{+1}$ ( C hina Fold Belt (Guo LZ et al., 1965; Cawood et al., 2018). This orogeny r as folluwed by deposition of thick sequences of Middle-Upper Devonian molasse ana quartz sandstone, which unconformably coverred the folded and metam srinsed pre-Devonian strata. Thus, the subductionand collision-related compressive stress on both the southern and northern margins of the South China Blok night be significant driving-forces triggering the folding/thrusting of $\ldots$ pe-Devonian strata and the Silurian granitic magmatism within the South Chi a Block.

In addition, paleomagnetic data indicate that the Viet-Khmer Block in the Southeast Asian region was previously distributed along an E-W strike and the rotation involved not only the Viet-Khmer Block but also the entire the Indochina region. This block was rotated clockwise for $30^{\circ}-40^{\circ}$ in the Cenozoic (Sato et al., 2001; Yang and Besse, 1993; Yang ZY et al., 2001) due to the extrusion tectonism in the eastern margin of the Tibet Plateau, well interpreting its present occurrence of the NW-trending Songma-Ailaoshan orogenic belt. 


\section{Late Paleozoic-Early Mesozoic evolution: responses to the closure of the Paleo-Tethys Ocean}

\subsection{Late Paleozoic-Early Mesozoic sedimentary environment}

From the Middle Devonian (in Cathaysia) or Late Devonian (in Jiangnan) to the Middle Triassic period, the South China Block was situated in a stable coastal-neritic depositional environment of an archipelagic framework (Fig. 13D). In the Middle Devonian, the depressions of the northern Cathaysia depositional region were commonly filled by terrestrial coarse-grained clastic roci. such as conglomerate, quartz sandstone, arkose and sandstone (Fig. 14).

From the Early Carboniferous to Middle Triassic the sedimentary sequences of the Jiangnan and Cathaysia depositional regions wt: similar, and characterized by platform-facies and coastal-neritic-facies carbon ${ }^{+}{ }^{+e s}$ (limestone, bioclastic limestone and dolomite) intercalated with cherts (Fig. in), containing abundant floral fossils of Leptophloeum rhombicum Dawson, an taunal ones such as Fusulina, Coral, Brachiopoda and neritic Radiolariar. $\mathbf{w}^{\prime}$ ich are observed in the Jiangnan depositional region and the Yongan-Meizhou 'asin anu the Shaoguan-Zhaoqing-Maoming basin of the Cathaysia region. Neither la $g_{1}$-scale volcanism nor slices of oceanic crust were documented in the Upper De vir in to Middle Triassic strata. Occasionally, intraplate


(Shu LS et al., 2006, 2078b)

Our studies sug gesı that the depth of the basins and the thickness of strata gradually increase fru $m$ the northeast to the southwest (Shu LS et al., 2008c). In the Qinzhou Bay area (QZB in Fig. 13D) of the southwestern Cathaysia region, the thickness of Upper Paleozoic strata is more than 10,000 m. Meanwhile, a short-term uplift took place in the Middle Permian, leading to formation of coastal swamps, as represented by arkoses and coal layers (Shu LS et al., 2009). Whereas, in the southwestern Yangtze Block, the Late Permian mantle plume activity has generated the huge-scale Emeishan flood basalts known as the Emeishan Large Igneous Province (Xu YG et al., 2001).

5.2 The Early Mesozoic deformation: a response to the closure of the Paleo-Tethys Ocean 
In the Early-Middle Triassic period, the closure of the Paleo-Tethys Ocean (Wang YJ et al., 2007; Zhao GC et al., 2018) led to a strong tectono-magmatism within the South China Block (Fig. 13E, 14). The Upper Paleozoic coastal-neritic carbonates and clastic rocks were folded and brittlely faulted, deformed by strike-slip ductile deformation.

An Early Mesozoic continental deep-subduction took place in the northern margin of the Yangtze Block along the E-W-trending Dabie-Qinling Orogenic Belt (Fig. 1) between the South China and North China blocks (Hacker et al., 1998; Faure et al., 1999; Dong YP et al., 2011; Li SZ et al., 2012). At the southwestern margin of the South China Block, the collision between the South Clin' occurred along the Songma (in northern Vietnam)-Ailaos an in Yunnan) suture zone (Figs. 1 and 13E), generating the Songma-Ailaosh $\mathrm{n}$ o phiolitic mélange. Ductile strike-slip shear zones and peraluminous granitic nlu ${ }_{2}$ nns dated at 250-220 Ma were also developed (Lepvrier et al., 1997, 2004; Roy ${ }^{\text {r }}$ et al., 2012; Faure et al., 2014, 2016a, b).

Within the South China Block, sevial iveoproterozoic phyllite klippens were thrusted southwards onto the $\mathrm{C}$ : ho he ifferous-Permian limestone strata along a low-angle fault as seen in the Pi.. xiang-Leping basin (Shu LS et al., 2009). On the northern and southern slopes c $i$. Wuyi terrrane and within the Yunkai terrane, ductile strike-slip shearing s cru-tures are developed, partly replacing the previous thrusting structures. The s. ngle-grain ${ }^{40} \mathrm{Ar} /{ }^{39} \mathrm{Ar}$ dating of newly formed mica from mylonitic rocks yieldec age, of 240-200 Ma (peak age at ca. $230 \mathrm{Ma}$ ), coeval with the peak age of regi nal Jranitic plutonism (Fig. 15; Wang YJ et al., 2007; Lin W et al., 2008; Charvet et à'., 2010; Shu LS et al., 2015).

This tectonic event intensively reworked the pre-Devonian deformed structures (Shu LS et al., 2009) and is widely recorded in rocks in the eastern Jiangnan Orogenic Belt and the southwestern Yunkai terrane. To the northwest of the Xuefeng mountains, large-scale thin-skinned structures including box folds, fold-and-thrust structures are well developed (Figs. 2 and 13E; Chu Y et al., 2012a, b; Zhang GW et al., 2013). Furthermore, at depth, a syn-metamorphic, NW-directed ductile shearing developed to accommodate the $\mathrm{km}$-scale displacement of the entire Neoproterozoic to Middle Triassic sedimentary cover of the South China Block, leading to refolding of the Early Paleozoic structures during the Triassic intracontinental orogeny. To the southeast of the Xuefeng mountains, the Early Paleozoic folds were almost totally reworked by the 
Early Mesozoic deformation structures (Shu LS et al., 2008c, 2009). In the Nanling terrane, three E-W-trending granite zones with an average width of 40-50 km were generated and dated at 228-205 Ma (Zhou XM et al., 2006; Shu LS et al., 2008b). The Lower-Middle Triassic are unconformably covered by a several kilometers thick molassic sequence (Shu LS et al., 2006, 2008b).

\subsection{Early Mesozoic magmatic response to the closure of the Paleo-Tethys Ocean}

Under the aforementioned compressional setting, widespread magmatism took place in the Jiangnan and Cathaysia regions, forming a $6 r 0-800 \mathrm{~km}$ wide and 1,200 $\mathrm{km}$ long granitic domain. The Early Mesozoic granite $e_{{ }_{x}}$ 'sures occupy a surficial area of more than $15,000 \mathrm{~km}^{2}$ (Song MJ et al., 2017). $\therefore$ lu of zircon U-Pb and mica ${ }^{40} \mathrm{Ar} /{ }^{39} \mathrm{Ar}$ ages ranging from 240 to $220 \mathrm{Ma}$ were clita ${ }_{\ldots}=\mathrm{d}$ from 189 granite samples (Table S3), which might be the timing of the Earl $r$ M sozoic intracontinental orogeny. From several NW-SE and NE-SW trending sec:ons across the Jiangnan and Cathaysia regions, the Early Mesozoic g. nit ss show an overlapping age range without any regular trend (Shu LS et as. 'c'7b; Wang YJ et al., 2010, 2012b; Song MJ et al., 2017).

About $97 \%$ granitic plutons she'v peraluminous geochemical signatures and are rich in muscovite and tourmalıre. The magmatic zircons yielded negative $\varepsilon \mathrm{Hf}(\mathrm{t})$ values (-2.2 to -14.3 with $?_{1}$ qverage of -7.3 ) (Table S3) and two-stage model ages from 1.41 to $2.28 \mathrm{Ga}$, s.og sting that they were generated by partial melting of ancient continental cr.rt ( 'ang YJ et al., 2010, 2012b; Song MJ et al., 2015; Shu LS et al., 2014, 2015, Su..ral I-type plutons (<3\% of all Early Mesozoic granites) were also identified an considered to have been derived from partial melting of mafic lower crust (Song MJ et al., 2015). The magmatic zircon U-Pb ages range from 245 to $205 \mathrm{Ma}$ (Zhou XM et al., 2006) with a peak at 240-220 Ma. These S-type plutons also display syn-magmatic deformation fabrics and syn-magmatic metamorphism. Gneissic granites, augen granites and granitic gneiss commonly developed along the margins of some plutons, whereas the country rocks away from plutons were not subjected to middle-high-grade metamorphism (Shu LS et al., 2015), comparable to the Early Paleozoic granites. 


\subsection{Late Triassic - Early Jurassic widespread angular unconformity}

The Early Mesozoic tectonism displays variations across the South China Block (Shu LS et al., 2008c, Wang YJ et al., 2013). In the western Cathaysia Block, close to the Ailaoshan-Songma suture zone, the Upper Triassic strata consist of purple-red conglomerate-sandstone layers and overlie the Upper Permian strata with an angular unconformity. In the middle Cathaysia Block, the Upper Triassic strata consist of coarse-grained terrestrial clastic rocks and covers the Lower Triassic carbonates by an angular unconformity. In the eastern Cathaysia Block, the Upper Triassic coarse-grained sandstones overlie unconformably the 1 rmian carbonate strata. Locally, the Lower Jurassic conglomerate and quartz sanc stone contact with the pre-Mesozoic strata by an angular unconformity (Fig. 14; Shu LS et al., 2008c, 2009; Wang YJ et al., 2013).

In the western Jiangnan Orogenic Belt, the iv idd e Triassic granitic plutons dated at ca. $230 \mathrm{Ma}$ are overlain by the Upper Tr. ssic granite-derived conglomerate and arkose sequences (Shu L S et al., 2008c) In :..e middle Jiangnan Orogenic Belt, the Upper Triassic is composed of purr e c sal-bearing coarse-grained clastic rocks, and they overlie unconformably the Middle iriassic and Permian carbonates (Fig. 14). In the eastern Jiangnan Orogenic ${ }^{{ }^{\prime}} x^{1+}$. the Upper Triassic coal-bearing coarse-grained clastic rocks cover unconform a ${ }^{\prime} l y$ ine Neoproterozoic schist and gneiss (Shu LS et al., 1995; Xiao and He, 2005) Nea: the Nanjing city of the northeastern Yangtze Block, the Upper-Middle Triassı conglomerate and quartz sandstone strata overlie unconformably the Farly Triassic thin-bedded limestone (Fig. 14).

The aforementı ned arguments suggest that the Early Mesozoic closure of Paleo-Tethys Ocean has strongly affected the South China Block, and terminated the marine environment, entering a fluvial-lacustrine sedimentary environment.

\subsection{Continental dynamic mechanism for the Early Mesozoic tectonism}

As mentioned above, the Upper Devonian to Middle Triassic stratigraphic sequences in the South China Block are composed of limestone, dolomite, chert, mudstone, coal-bearing sandstone and arkose with various fossils, indicative of stable sedimentary environments of continental shelf, coast, lacustrine and river-delta (Fig. 14; Shu LS et al., 2008b). The Early to Middle Triassic magmatic rocks are mostly 
peraluminous, with rare or no mantle-derived components, suggesting that there was no subduction of oceanic crust at this period (Song MJ et al., 2015, 2017; Shu LS et al., 2018).

The Early Mesozoic compression resulted in folding of all the pre-Middle Triassic strata and associated faulting that crosscut the pre-Triassic strata. The Upper Triassic conglomerate and coarse-grained sandstone overlie unconformably the Lower Devonian to Lower Triassic strata (Fig. 14), suggesting that the tectonic event took place in the Middle Triassic period. Some researchers nroposed a hypothesis of flat-slab subduction to interpret wide and strong deformat on in the Early Mesozoic in the inland areas of South China (Li and Li, 2007).

Available data indicate that in the Early Masuzoic, the South China Block subducted beneath the North China Block and ginerated the Dabie-Qinling UHP metamorphic-deformed zone (Fig. 1; Gildt • et al., 1999; Faure et al., 1999, 2003; Zheng YF et al., 2003; Li XH et al., _00 ); Lı SZ et al., 2012; Zhang GW et al., 2013; Wu and Zheng, 2013). Meanwhile, the Paleo-Tethys Ocean subducted beneath the Indochina Block, followed by th - assembly of the South China Block with the Indochina Block (Carter A e ${ }^{+}$al., 2001; Faure et al., 2014; Shu et al., 2015). These two compressive stress fields गn :oth the northern and southern sides of the South China Block might be the : vilug forces for the Early Mesozoic intracontinental folding, faulting and crustar thickening as evidenced by partial melting of crust and S-type granitic magmatism (Fig. 13E, 15; Shu et al., 2008b; Wang YJ et al., 2007, 2012b; Faure et al., 2016b; Song MJ et al., 2017; Li JH et al., 2017). Therefore, the Early Mesozoic tectono-magmatic event within the South China Block is an intracontinental reworking event due to far-field effects of plate convergence surrounding the South China Block (Fig. 13E; Shu LS et al., 2008b, 2009, 2018; Charvet et al., 2010; Zhang GW et al., 2013; Faure et al., 2016b, 2018b).

\section{Consumption of the Paleo-Pacific Ocean: the active continental margin and basin-and-range tectonics}




\subsection{Tectonic transition from the E-W-trending to NE-trending regimes}

Following the Early Mesozoic tectono-magmatic responses to the closure of the Paleo-Tethys Ocean, a regional-scale tectonic transition from the E-W-trending tectonic regime with Paleo-Tethys affinity into the NE-trending regime with Paleo-Pacific affinity happened in the East Asia region (Ren JS et al., 1990, 1998; Wang and Shu, 2012). In the Late Triassic-Early Jurassic period, uplift and erosion took place in the southeastern region of the South China Block and is evidenced by the absence of Upper Triassic strata and formation of Lower Jurassic conglomerate layers with a thickness of 50-80 m (Shu LS et al., 20 . . Wei W et al., 2016). Meanwhile, crustal extension and thinning happened in $\mathrm{t}$ ie $\mathrm{w}$ zstern Wuyi terrane and formed a sub-E-W-extending Middle Jurassic volcani :-se 'imentary basin (Shu LS et al., 2009) of $30-40 \mathrm{~km}$ wide and $250 \mathrm{~km}$ lon referred to as the western Fujian-southern Jiangxi-northern Guangdong or the Yongding-Meizhou half-graben basin zone (Fig. 16), in which 180-160 $\mathrm{M}_{\mu}$ greenish vesicular alkaline basalt and reddish rhyolitic rocks of 300-800 m thir c wue accumulated (Shu LS et al., 2009). This was the most intensive volcanic erv ption in South China since the Late Tonian.

In the Nanling terrane of so thern Fiunan Province, three phases of intrusion of mantle-derived mafic magma $\mathrm{t}, \mathrm{o}$ : prace at $\sim 175 \mathrm{Ma}, 150-125 \mathrm{Ma}$ and 95-80 Ma along the Chenzhou-Linwu fr. ui willch was interpreted as a Late Mesozoic upwelling path of mantle-sourced ma ma (Fig. 16; Wang YJ et al., 2003). In the Jiangnan region, intrusion of diabase and gra itic dykes mainly occurred during 150-145 Ma and were asssociated with hų e-sc ale skarn-type scheelite polymetallic deposits (Chen GH et al., 2016). Meter-sca $>$ mafic dykes and coeval alkaline granites of 180-150 Ma also occur along the margins of half-graben basins in the Nanling terrane (Deng P et al., 2004; Zhou and Chen, 2001; Shu LS et al., 2009).

The E-W to NE-SW trending Late Jurassic peraluminous granitic zone is generally oblique to the E-W-trending Middle Triassic plutonic zone in the Nanling terrane (Zhou XM et al., 2006). Therefore, the Nanling terrane could be the most reasonable place that documents the tectonic transition from the E-W-trending to NE-SW trending regime in the Middle Jurassic (180-160 Ma; Deng P et al., 2004; Shu LS et al., 2009, 2012) when the low-angle subduction of the Paleo-Pacific Ocean (Izanagi) lithosphere beneath the East Asian continental margin started.

The subduction zone of Paleo-Pacific Ocean in the Late Mesozoic was recorded 
in various rocks (ophiolitic rocks and blueschists) in many areas, such as the Sanbagawa zone of southwestern Japan, the Longitudinal Valley of Taiwan of China, and the Mindoro-Palawan of western Philippines (Faure et al., 1989; Ichikawa et al., 1990; Shu and Zhou, 2002). Recently, field observations and tectonic analyses suggest that the time of tectonic transformation from the Tethys to Paleo-Pacific tectonic domain probably took place in the Early-Middle Jurassic in the South China Block (Shu and Zhou, 2002; Zhou et al., 2006; Zhou et al., 2009; Shu LS etr al., 2009; Wu FY et al., 2011; Guo F et al., 2015). As a part of the Paleo-Pacific tectonic regime, a wide back-arc extensional region developed in the Southeast China, forming a huge-scale NE-SW trending volcanic and plutonic complex «'ne dated at 140-110 Ma, and numerous contemporaneous rift basins (Fig. 16; Van, and Shu, 2012). The Ganjiang and Sihui-Yangchun-Wuchuan fault zones (Fig. 16) were identified as the terminal line of the Late Mesozoic volcanic rocks 'sinu XM et al., 2006; Wang and Shu, 2012).

The NE-SW trending Lower Cretaceo is volcanoclastic, volcanic and intrusive rocks occupy almost the whole southeasi Chına coastal region, and overprinted the previous E-W trending structures is t'e inland areas as seen in the Nanling and Yunkai domains (Charvet et al., :994; Lapierre et al., 1997; Wang and Zhou, 2002; Zhou XM et al., 2006).

\subsection{Tectonic effects of the Palle - Yacific Ocean subduction}

In the Late Jurassic-En -ly Cretaceous, the subduction of the Paleo-Pacific Plate accelerated along a low ang ie subduction zone (Zhou and Li, 2000; Kato and Saka, 2006), forming a b oad active continental margin in the East Asian region. The Japanese islands belo iged to a volcanic arc while Southeast China was mainly in a back-arc extension region (Ichikawa, 1990; Faure et al., 1986, 1992; Wang and Zhou, 2002; Shu and Zhou, 2002; Wang and Shu, 2012). Consequently, the Early Cretaceous rhyolitic volcanic rocks, bimodal magmatic dykes, metamorphic core complexes, co-existing I- and S-type granites dated at 140-100 Ma, rift basins and thinning lithosphere occurred in both the southeast coastal region and the inland areas, evidencing a back-arc extensional setting (Zhou et al., 2006; Shu LS et al., 2009).

Meanwhile, a major tectono-magmatic event affected the East Asian margin and formed the ophiolitic mélange and HP/LT metamorphic zone in the southwestern Japan, Central Taiwan, Mindoro and Palawan areas (e.g. Ichikawa, 1990; Lo and Yui, 1996). In Japan, this event is assigned by some authors to the collision of the 
Proto-Japan Block with the South Kitakami-Kurosegawa Block (Faure, 1985; Faure et al., 1986; Faure and Natal'in, 1992; Otsuki, 1992; Kato and Saka, 2003, 2006). This collision was possibly responsible for the formation of the NE-SW trending Changle-Nan'ao ductile shear zone in the southeast coast of South China (Fig. 16), which was dated at $120-100$ Ma by muscovite ${ }^{40} \mathrm{Ar} /{ }^{39} \mathrm{Ar}$ method (Wang ZH et al., 1997). This event formed a regional angular unconformity between the Late Cretaceous coarse-grained clastic rocks and the underlying Early Cretaceous volcanic rocks in the SE China coastal areas (Lapierre et al., 1997; Wang and Shu, 2012).

Possible break off of the subducted oceanic lithosphere might have resulted in the roll-back of the subducting slab and induced a shift fron. 'nw-angle to high-angle subduction of the Pacific lithosphere since the Late Cre acer us (Uyeda, 1983; Zhou and Li, 2000; Guo F et al., 2021). Such a change corrt spol ded to a large-scale crustal thinning and further continental extension, forming a series of NE-SW rift basins in South China and Northeast China. These wans were filled by the Late Cretaceous-Paleogene red clastic rocks of th 01 sands of meters thickness, interbedded with alkaline basalts and were intruded b, manc dykes (Fig. 16). An alkaline granite zone dated at 100-70 Ma was also Ier jloped well along the East Asian continental margin (Zhou XM et al., 2006; Si’’ ' LS et al., 2009; Li JH et al., 2020).

Based on the above-mentio 1e ${ }_{\star}$ field observations and data patterns across South China, we suggest that tie Early Cretaceous low-angle subduction of the Paleo-Pacific plate causeci nartial melting of the subducted slab. In the depth, an upwelling of mantle-de ivec magma, and basaltic underplating along fault zones, led to softening and paitial nelting of middle-lower crust, along with granitic plutons emplacement in the 4 sper plate (Fig. 17). These processes generated the Cretaceous rift structures, leading to the basin-and-range tectonics in South China (see below).

\subsection{Extensional tectonics and related magmatism}

\subsubsection{Basin-and-range tectonics}

In the Early Cretaceous, when a hypothetical low-angle subduction of Paleo-Pacific slab happened, the southeast China coastal zone was situated in the back-arc region behind the Japanese volcanic arc (Wang and Shu, 2012). The southeast China coastal back-arc extensional zone is characterized by lithospheric thinning, namely, the thickness of the crust is only $29 \mathrm{~km}$, and the lithosphere is 80 
km thick (Zhou XM et al., 2006). The extensional basins were filled by $2-3 \mathrm{~km}$-thick Cretaceous rhyolite-pyroclastic rocks and terrigenous clastic rocks. Coeval metamorphic core complexes and normal-fault-bounded granitic domes were also reported in the Wugongshan (Faure et al., 1996; Wang DZ et al., 2001), Lushan (Lin W et al., 2000), Zhuguangshan (Fig. 16) and Hengshan areas (Shu LS et al., 2004; Wei $\mathrm{W}$ et al., 2016). A distinctive Late Mesozoic high-Nd abnormal zone occurred and corresponds to a coeval granitic and poly-metal metallogenic zone (Gilder et al., 1996). The volumes of plutons increase and their ages show a younging direction gradually from the inland to the coast (Zhou XM et al., 2006).

The Late Mesozoic basins in Southeast China have . total surficial area of $128,000 \mathrm{~km}^{2}$ (Shu LS et al., 2009), comparable to the tal exposure of the coeval magmatic rocks $\left(140,000 \mathrm{~km}^{2}\right.$; Fig. 16; Zhou XM et a , 21 06). Most of the rift basins were formed in the Middle Jurassic (180-160 M $)$ a $a_{1}+1$ have a total surficial area of $4,600 \mathrm{~km}^{2}$. The Late Jurassic-Early Cretaceous $v^{\wedge}{ }^{\prime}$-nic grabens occupy a total area of $85,500 \mathrm{~km}^{2}$, and total area of the non- 0 anic ones (called the redbed basins) formed in the Late Cretaceous to Paleooei. ' is $51,900 \mathrm{~km}^{2}$ (Shu LS et al., 2009).

The basin-and-range tectonics : $\_$distinct character of the Southeast China region during the Cretaceous. Fru $\eta$ the coast to inland, a series of magmatic ridges is

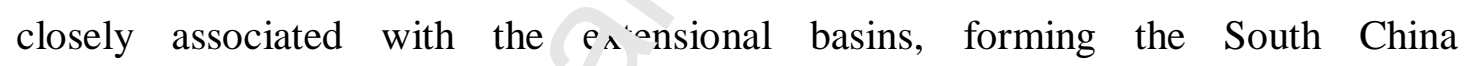
basin-and-range tectonics (G: idt: et al., 1991; Shu LS et al., 2004, 2009, 2020; Wang and Shu, 2012). The majc basin-and-range systems are: (1) in the southern Wuyi domain, the NE-trc adin; Early Cretaceous granitic batholiths in the Daiyunshan-Bopingl ng range (peak altitude of $1,856 \mathrm{~m}$ ) coupled with contemporaneous vo zanic basins on both sides of the range; (2) in the Wuyi mountains, the NE-trending Early Cretaceous granitic batholiths (peak altitude of 2,157 m; Fig. 16) coupled with a Late Cretaceous-Paleogene rift basin zone on its northwestern side and an Early Cretaceous volcanic basin on its southeastern side; (3) in the northern Wuyi domain, the E-W-trending Early Cretaceous granitic plutons (peak altitude of 1,918 m) coupling with the Pingxiang and Anfu rift basins, formed the Wugongshan metamorphic core complex which was superimposed on a Triassic dome; (4) in the Nanling domain, the E-W-trending Late Triassic-Early Jurassic granitic zone (peak altitude of 1,902 m) coupled with coeval sedimentary basins was intruded by the NE-trending Early Cretaceous plutons, forming the famous Five Ranges landform (Wang and Shu, 2012; Shu et al., 2020). 


\subsubsection{Multi-sourced igneous rocks}

The Zhenghe-Dapu fault zone (Fig. 2) is a boundary between I-type (140-110 Ma) and S-type (170-150 Ma) magmatic domains. Rhyolitic volcanic rocks and alkaline granites, as well as mafic plutons/dykes, are widespread on its southeast side, i.e., the coastal area; whereas, S-type plutons mostly outcrop on its northwest side, i.e., the inland region (Fig. 17). This fault zone was a normal one dipping to the southeast and was formed in the Mesozoic.

The bimodal igneous rocks were formed in two stages, i.e., mainly in the Middle Jurassic and secondly in the Early Cretaceous. The E-W-trending Middle Jurassic bimodal igneous rocks are mainly distributed in the Yongd ${ }_{\mu_{2}}{ }^{2}$-Dingnan-Shixing zone of the western Wuyi-Nanling domain (Figs. 16 and 17) w. 'ere he basalts and rhyolites have approximately equal thickness. The cryptocrysta. line and vitric textures reflect a rapid extensional setting (Deng P et al., 2004). Smali scale aegirine-bearing granites were also observed. The NE-SW trending Early $C_{1}{ }^{\text {tace }}$ ceous bimodal igneous rocks are mainly distributed in the southeastern China 0 stal areas and are mainly composed of rhyolites and basalts, with an exposure ra: $)$ of 10:1. The basalts belong to continental tholeiites, which are distinctively dif are at from the Middle Jurassic alkaline basalts in the Nanling domain. The positiv $\varepsilon \mathrm{Hf}(\mathrm{t})$ values $(+2$ to +5$)$ of rhyolites reflect the involvement of mantle-derived na « rial or crust-mantle interaction (Zhou XM et al., 2006).

The Late Cretaceous a.' aline granites occur in an $800 \mathrm{~km}$-long southeast coastal area (Wang and Shu, 2712) A-type granites were emplaced during 160-150 Ma in the Nanling and at 1 10-5) Ma in the coastal region (Zhou XM et al., 2006; Wang and Shu, 2012), whereas -type granites mainly range in age between 140 and $110 \mathrm{Ma}$ (Wang and Zhou, 2002). Alkaline granites usually have many geodes that are often filled by quartz, muscovite and alkaline mafic minerals, indicating a shallow emplacement depth. Geochemical data suggest that the alkaline granites were all produced by crust-mantle interaction in an extensional setting (Wang and Zhou, 2002; Zhou XM et al., 2006).

To the west of the Zhenghe-Dapu fault zone, granites are mostly peraluminous and were emplaced at 170-150 Ma (Wang and Shu, 2012). Porphyritic texture and massive structure were commonly developed. The long axes of granitic batholiths are mostly oriented NE-SW, occasionally accompanied by volcanic basins. Sometimes, the granitic batholiths are covered by rhyolite and welded tuff, constituting a volcanic 
and intrusive complex (Zhou JC et al., 2006; Wang and Shu, 2012). These rocks may be derived from deep melting of subducted slab, upwelling of mantle material and partial melting of continental crust (Zhou and Li, 2000).

\section{Discussion on some controversial issues}

\subsection{The location of the Neoproterozoic suture/rifting zone in the middle segment of the Jiangnan Orogenic Belt}

The Neoproterozoic rocks within the Shaoxing-Pingx ang fault zone (the eastern Jiangnan segment) and the Quanzhou-Longsheng fault (the western Jiangnan segment) comprise ophiolites, arc-type andesites and in jutes with ages of 980-840 Ma, documenting a suture zone between the Yangtz anu Cathaysia blocks. However, it is difficult to identify the location of the suture 'ont in the middle Jiangnan segment situated in the Hunan Province due to the abser ce of Neoproterozoic magmatic rock and other geological evidence. According th or $:$ recent field investigations covering both the Jiangnan Orogenic Belt an $\_$athaysia Block, we have identified that the litho-stratigraphic sequences on each s: te of the Pingxiang-Qidong-Quanzhou fault zone (Fig. 2) show distinctive roc' assemblages from upper to lower. (1) The Cambrian and Ordovician seanen $\bullet$, are characterized by trilobite-sinoceras-bearing carbonate rocks and graph th bearing material layers in the Jiangnan region to the north of the fault zone $\left(\mathrm{F}_{\varepsilon}-13 \mathrm{~A}-\mathrm{C}\right)$ whereas the Cathaysia region to the south of the fault zone is marker 'v sraptolite-bearing sandy-muddy slate and phyllites (Fig. 18D-F). The lowt t aivozoic graphitic material bearing layers and limestone are absent in the Cál.adysia region. (2) The Ediacaran sequence in Jiangnan is characterized by black chert, dolomite, siliceous limestone and limestone while in Cathaysia it is a suite of sandstone and mudstone. (3) The Cryogenian tillite layers are well developed in Jiangnan, but are absent in Cathaysia. (4) The Upper Tonian (corresponding to the Nanhua System) contains bimodal volcanic rocks in the Jiangnan region, but is rare in the Cathaysia region. (5) The Lower Tonian (corresponding to the Sibao Group) in the Jiangnan region is marked by sandy-muddy flysch slates intercalated with meta-volcanic and mafic-ultramafic rocks; whereas the equivalent strata in the Cathaysia region are characterized by various sandy-muddy slates and phyllites with no or only sporadic mafic rocks. 
The above-mentioned distinct features of the Jiangnan and Cathaysia regions indicate that since the Late Tonian (or Nanhua period), this fault zone divided the united Yangtze-Cathaysia tectonic unit, namely, the Proto-South China Continent into two tectono-stratigraphic regions, Jiangnan to the north and Cathaysia to the south. We interpret that these differences as the results of the Late Tonian rifting event along the previous suture zone (Shu LS et al., 2020). Here, we define the Pingxiang-Qidong-Quanzhou fault zone as the location of the Neoproterozoic rift zone, which most probably re-activated the pre-existing I'eoproterozoic suture zone in the middle Jiangnan segment. This result has bee $1 \mathrm{rc}$ sently confirmed by a geophysical investigation which presents obvious g avit and magnetic anomalies along this fault zone (Guo and Gao, 2018).

\subsection{The nature of the "Cathaysia Oldland"}

\subsubsection{Study history of the "Cathaysia O' 1laı..."}

The term "Cathaysia Oldland” , ras firstly proposed by Grabau (1924) and refers to a hidden crustal block beneath the South China Sea, whereas the Wuyi domain, composed of pre-Devonian metar 10 phic rocks, was defined as a geosyncline region (Grabau, 1924). The term ra adopted by Huang JQ et al. (1945) in their studies. In the 1960-1970's, some rest. rchers identified the Cambrian and Ordovician graptolite fossils from the Cat hay: ia Block which was originally assigned to the "Cathaysia Oldland". Thus, the erm "Cathaysia Oldland" was re-defined as the South China Early Paleozoic Fold Belt (Guo LZ et al., 1965) or the Ediacaran to Early Paleozoic fold belt (Ren JS, 1964, 2001). Since the 1980's, with the application of advanced dating techniques, a large number of Proterozoic ages were obtained from meta-igneous rocks in the Wuyi terrane (Gan XC et al., 1993; Wan YS et al., 2007; Yu JH et al., 2009), leading to re-use of the concept "Cathaysia Oldland" (Shui T, 1988), which is, however, not accepted by other researchers (Wang and Zhou, 2002; Shu, 2006, 2012; Ren and Li, 2016). Therefore, the Cathaysia Oldland became a major debated issue. 
The Cathaysia Block was recently considered as a geological unit consisting of widely exposed Precambrian sandy-argillaceous slate-phyllite series interlayered with meta-mafic rocks, along with Early Paleozoic graptolite-bearing clastic rocks, both are intruded by Silurian peraluminous granitoids. The pre-Silurian strata are up to 10,000 meters thick and occupy an area of $80,000 \mathrm{~km}^{2}$ of the Cathaysia Block, and are covered by a 300-500 m thick Middle Devonian conglomerate, coarse sandstone and quartz sandstone.

\subsubsection{Re-evaluation of usability of "Cathaysia Oldland"}

As mentioned above, the geological features of Cathc ysla can be summarized as several aspects as the follows. (1) Very limited occi rren e of old continental core. Although an unexposed Archean basement might axist in Cathaysia as revealed by 4.1-3.8 Ga detrital zircons (Xu XS et al., 2005; Xıng and Shu, 2010; Yao JL et al., 2011; Xing GF et al., 2014), the in-sitı D dle sproterozoic basement (1.8-1.9 Ga) occurs only in the northern Wuyi ter ant (Yu JH et al., 2009). (2) Complex genesis of sporadic Neoproterozoic magm^tic rocis dated at 980-910 Ma. Neoproterozoic magmatic rocks were recognize $\perp_{1}$, several isolated terranes and formed in different tectonic settings, including ( $\leadsto$ the continental arc-type rhyolites in the Nanling terrane (Shu LS et al., 2008a), th • su hduction-related gneissic granites (Liu BX et al., 2001) and amphibolite and ' rere in the Wuyi and Yunkai terranes (Wang YJ et al., 2012a, 2013a); (b) gneissic ¿ranitoids related to the formation and closure of back-arc basins in the Yunkai terrane (Wang YJ et al., 2014); and (c) mantle-derived mafic rocks generated in continental rifts, such as gabbro and basalt along the Zhenghe-Dapu fault zone of the Wuyi terrane (Shu LS et al., 2011), and basalt, diabase and gabbro in the Yunkai terrane (Wang YJ et al., 2010). (3) Intense Phanerozoic tectonic and magmatic reworking. Most importantly, all the pre-Devonian rocks were involved into a Late Ordovician to Silurian syn-metamorphic deformation and thrusting system documented in the Wuyi, Nanling, Yunkai and Xuefeng domains (Shu LS et al., 2008c; Ren and Li, 2016), associated with intrusion of S-type granitic plutons with ages of 
440-420 Ma (Shu LS et al., 2015, 2018; Wang YJ et al., 2010).

Based on the above-mentioned geological facts, the Cathaysia Block seems to be characterized by small-scale exposures of ancient rocks, weakly crystallized basement, and poor rigidity. Considering the definition of an oldland, we propose that the previous term "Cathaysia Oldland" is not suitable to be used for Cathaysia.

\subsection{Initial formation age of the South China Block}

\subsubsection{History of studies}

The formation of the South China Block (or the Prc ${ }^{+} \mathrm{c}-$ South China Continent; Zhang GW et al., 2013) has long been debated. In 1 99 's, the timing of initial stabilization was inferred as Meso-Neoproterozoic cco ding to litho-stratigraphic comparison, structural correlation and isotopic da al., 1995; Charvet et al., 1996), and was linked v.'th the global Greenville period subduction and collision ( $\mathrm{Li}$ ZX et al. 15,9 ). Nevertheless, Hsu et al. (1990) proposed that the South China Blor $\mathrm{N}$ as an Appalachian-type Mesozoic orogenic belt and experienced a long-term depostional and tectonic evolution. Since the 21th century, with increasing geoch $\mathrm{O}^{\text {' }}$ 'ngical data, the formation of the Proto-South China Continent once again v as s-determined as at 860-800 Ma (Shu LS et al., 1994, 2011; Li ZX et al., 1999; : i $>$ 'H et al., 2003; Li WX et al., 2008), 830-800 Ma (Yao JL et al., 2013, 2019; 7... ny YZ et al., 2012, 2015; Yan CL et al., 2017, 2021) and 820-795 Ma (Sun J, at al., 2018; Shu LS et al., 2019). Hence, the initial assembly of the South China Continent is essentially important in understanding the geology of the South China Block.

\subsubsection{The tectono-magmatism prior to the Proto-South China Continent}

The aforementioned dating data suggest that the Archean magmatic rocks dated at around 3.0 Ga only occur locally in the northern Yangtze Block (Fig. 5; Qiu YM et al., 2000; Zhang SB et al., 2006; Wu YB et al., 2009). They are assigned to the Kongling complex which is composed of schist, biotite-plagioclase gneiss, trondhjemite, granodiorite and a few mafic-ultramafic rocks (Gao S et al., 2011, Han 
QS et al., 2017). The early-middle Neoproterozoic mafic-ultramafic rocks, intermediate-mafic intrusive rocks and turbidites are mainly distributed in the southern, southeastern and western margins of the Yangtze Block and are dated at 980-845 Ma in the eastern Jiangnan (Xu B et al., 1992; Li XH et al., 1994) and 870-840 Ma in the western Jiangnan (Yao JL et al., 2016). Upper Tonian cover consisting of conglomerate and quartz sandstone sequences is widely exposed along the margins of the Yangtze Block.

As mentioned above, within the Cathaysia Block, n' mappable Archean rocks are observed. The Paleoproterozoic magmatic rocks $\mathrm{c}$ dtec at around $1.9 \mathrm{Ga}$ are exposed only in the northern Wuyi terrane. The wide pre: 1 Upper Proterozoic sandy slate and phyllite interlayered with meta-mafic ${ }^{2-d} \mathrm{~d}$ anitic rocks dated at 980-910 Ma are commonly exposed in the Cathaysia Block (. hu LS et al., 2008a; Li ZX et al., 2010; Wang YJ et al., 2012a, 2014).

Recent studies indicate that the arl sst plate tectonics in South China occurred in the Paleoproterozoic, as is evidenced by 2.1-1.9 Ga MORB-type ophiolite in the northern Yangtze (Han QS et a .., 2017) and the 1.9-1.8 Ga arc-type granitoids and amphibolite in the norther. W.yi terrane ( $\mathrm{Li} \mathrm{XH,} \mathrm{1998;} \mathrm{Yu} \mathrm{JH} \mathrm{et} \mathrm{al.,} \mathrm{2009),}$ suggesting that the subdu'tio of oceanic plate occurred in the Paleoproterozoic along the northern Yangtze ${ }^{\prime} \mathrm{C}_{\mathrm{n}}$ and the northern Cathaysia Block.

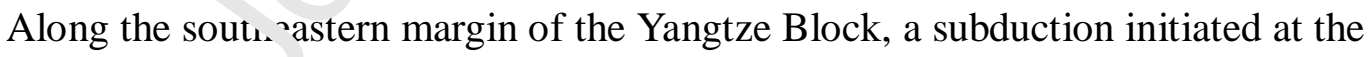
earliest Neoproterozoic and continued to the middle Neoproterozoic, as documented by the 940-900 Ma cumulate gabbro and plagiogranite of the SSZ-type ophiolite mélange along the Dexing-Shexian fault zone (Li XH et al., 1994; Li WX et al., 2003), the 980 Ma EMORB-type mafic rocks along the Shaoxing-Pingxiang fault zone (Wang XL et al., 2014a), the 870-845 Ma SSZ-type ophiolite and arc-type granite in the Huaiyu terrane (Zhang SB et al., 2012; Shu LS et al., 2019), the 870-840 Ma ophiolite and continental arc-type gabbro, diorite and granodiorite in the northern Guangxi terrane (Yao JL et al., 2016), and the 866 \pm 14 Ma high-pressure blueschist 
along the Dexing-Shexian fault zone (Shu LS et al., 1994, 1995; Zhou and Zhou, 1996). In addition, the 980-910 Ma arc magmatic rocks demonstrate that another subduction in the Cathaysia Block was also initiated at the earliest Neoproterozoic (Shu LS et al., 2008a; Li ZX et al., 2010; Zhang AM et al., 2012; Wang YJ et al., 2014), which were also considered as evidence of bi-direction subduction (Zhao GC, 2015).

\subsubsection{Forming time of the Proto-South China Continent}

The aforementioned Neoproterozoic peraluminous $g$-anites distributed linearly over 1,500 km within the Jiangnan Orogenic Belt and wer mostly formed during 840-810 Ma, constraining the timing of crustal thicke ing and partial melting related to the collision of the Yangtze and Cathaysia ble:-1, s, which is also the formation of the Proto-South China Continent (Wang XL et a1', ¿'114a; Xin YJ et al., 2017; Yao JL et al., 2019).

The regional-scale middle Neor roteızoic angular unconformity is well developed in the southeastern margin of ine Yangtze Block as shown in Figs. 5 and 6. It recorded a consistent sedime ta.inn shortly after the formation of the Proto-South China Continent. The bente itic silty tuff within the basal conglomerate from the lowest Banxi Group or th $\mathrm{K}$ 'vest Danzhou Group above the unconformity yielded a youngest age peak $\because$ a. $797 \mathrm{Ma}(803-791 \mathrm{Ma})$ that could constrain the oldest depositional age of $\backsim$ Banxi and Danzhou groups (Gao LZ et al., 2011; Yan CL et al., 2015; Wang LJ et al., 2010; Xu YJ et al., 2014; Wang XL et al., 2014b; Sun JJ et al., 2018; Yao JL et al., 2019). Similar youngest age peaks have also been obtained from the equivalent strata in the Cathaysia Block, indicating that the assembly of the Yangtze and Cathaysia blocks took place prior to $797 \mathrm{Ma}$. The dating of the bentonites and sandstones in the uppermost Lengjiaxi Group below the unconformity yielded a youngest age population of $829-820$ Ma with a peak at $\sim 825 \mathrm{Ma}$ (Gao LZ et al., 2011; Yan CL et al., 2015; Wang XL et al., 2014b; Li JY et al., 2016; Sun JJ et al., 2018). Consequently, the regional unconformity was formed during 820-797 Ma, 
which indicates the interval from uplifting and erosion to accumulation for the Jiangnan Orogenic Belt. Thus, the time of initial formation of the Proto-South China Continent was most likely at 820-800 Ma.

\subsection{The nature of the Early Paleozoic orogeny in Cathaysia}

The aforementioned geological facts suggest that in the Early Paleozoic the Jiangnan-Cathaysia region was in a stable littoral-neritic-slope depositional environment, with no oceanic or arc-type magmatic record. Folding, uplifting and peraluminous granitic magmatism initiated at ca. $460 \mathrm{Ma}$ and nded at ca. $390 \mathrm{Ma}$.

Three large-type Early Paleozoic orogenic belts wre documented in the Scotland-Norway, East Greenland and Appalachi $\sim$ ns uilts that resulted from the collision between Laurentia, Baltica and Avalon: blc cks (Williams, 1995; Mai et al., 1988; Mckerrow et al., 2000). Other five la a $^{3-s c a l e ~ E a r l y ~ P a l e o z o i c ~ o r o g e n i c ~ b e l t s ~}$ are exposed in the East Australia, the si thern Siberian margin, the Central-South Tianshan of NW China and the Qir." g-Kunlun belt of the central China, and the South China Fold Belt. In contrası to the other orogenic belts, the Early Paleozoic South China orogenic belt has no rzcorded any oceanic subduction features, such as ophiolitic mélange, arc ma smaic rocks, UHP-HP eclogite and HP-type granulite, as well as HP-LT blueschi`t. C ntribution of mantle material is rare or absent in the Late Ordovician-Early De ron an peraluminous granites (460-390 Ma) which were strongly deformed and show a dispersive distribution with no regular migration of magmatism, associated with regional lower greenschist facies metamorphism. These facts comprise the distinctive characters of the South China intracontinental orogenic belt as compared to other coeval subduction-collisional orogens (Table 1).

Table 1 Comparison of geological features of the Early Paleozoic South China intracontinental orogen with typical subduction-collision-type orogenic belts

\begin{tabular}{|l|l|l|}
\hline & $\begin{array}{l}\text { Intracontinental-type orogen } \\
\text { in South China }\end{array}$ & Subduction-collison-type orogens \\
\hline Location & $\begin{array}{l}\text { Far away from plate } \\
\text { subduction zone and collision }\end{array}$ & $\begin{array}{l}\text { Along the subduction and collision } \\
\text { zone of convergent plate margins }\end{array}$ \\
\hline
\end{tabular}




\begin{tabular}{|c|c|c|}
\hline & zone & \\
\hline $\begin{array}{l}\text { Depositional } \\
\text { environment }\end{array}$ & $\begin{array}{l}\text { Intracontinental } \\
\text { environment, terrigenous } \\
\text { muddy-sandy sediments with } \\
\text { rare or no pyroclastic rocks, } \\
\text { no deep-sea sediments, and } \\
\text { depositional sequences with } \\
\text { gradual transition within } \\
\text { basins }\end{array}$ & $\begin{array}{l}\text { Active continental margin setting, } \\
\text { varied lithological features, } \\
\text { turbidite with Bouma sequence, } \\
\text { abrupt change of sedimentary } \\
\text { facies within basins }\end{array}$ \\
\hline $\begin{array}{l}\text { Tectonic units } \\
\text { on two sides of } \\
\text { orogen }\end{array}$ & $\begin{array}{l}\text { Having same or similar } \\
\text { geological history }\end{array}$ & $\begin{array}{l}\text { Showing quite different geological } \\
\text { history }\end{array}$ \\
\hline $\begin{array}{l}\text { Trench-arc-type } \\
\text { rocks }\end{array}$ & No & 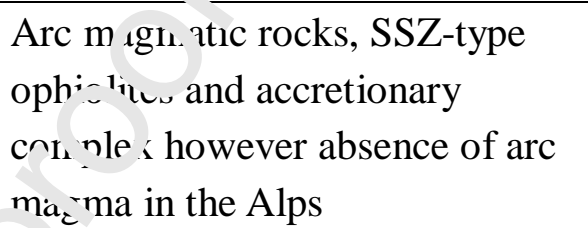 \\
\hline $\begin{array}{l}\text { UHP and HP } \\
\text { metamorphic } \\
\text { rocks }\end{array}$ & $\begin{array}{l}\text { Occasional and small-scale } \\
\text { occurrence of } \\
\text { high-temperature granulit }\end{array}$ & $\begin{array}{l}\text { H } 1 \text {-LT-type blueschist, UHP-HP } \\
\text {-type eclogite and HP-type } \\
\text { granulite }\end{array}$ \\
\hline Magmatic rocks & $\begin{array}{l}\text { Two-mica granite, miscivite } \\
\text { granite, tourmalin ard } \\
\text { cordierite-bearing granites } \\
\text { with syn- or prot-ı >llisional } \\
\text { settings }\end{array}$ & $\begin{array}{l}\text { Calk-alkaline volcanic rocks and } \\
\text { intrusive rocks, I-type granite, } \\
\text { juvenile crustal rocks like basalts, } \\
\text { gabbros, and post-collisional } \\
\text { peraluminous granitoids }\end{array}$ \\
\hline $\begin{array}{l}\text { Magma source } \\
\text { and evolution }\end{array}$ & 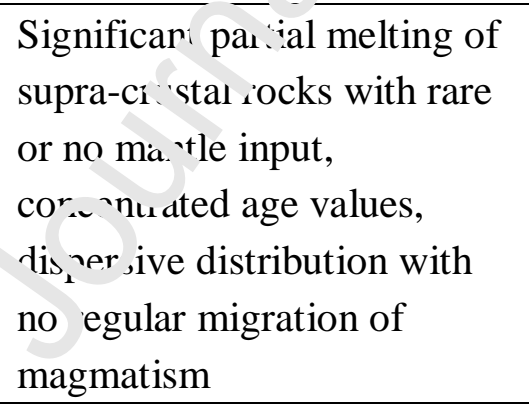 & $\begin{array}{l}\text { Mantle-derived compositions with } \\
\text { various degrees of crustal } \\
\text { contamination, regular polar } \\
\text { distribution and migration of } \\
\text { magmatism from plate margin to } \\
\text { inland both in composition and } \\
\text { age, and crustal melting }\end{array}$ \\
\hline $\begin{array}{l}\text { Deformation } \\
\text { and } \\
\text { metamorphism }\end{array}$ & $\begin{array}{l}\text { Widespread folding, thrusting } \\
\text { and ductile shear zones, } \\
\text { crustal thickening and lower } \\
\text { to medium-grade } \\
\text { metamorphism }\end{array}$ & $\begin{array}{l}\text { Widespread folding, thrusting and } \\
\text { ductile shearing zones, crustal } \\
\text { thickening and lower to } \\
\text { high-grade metamorphism }\end{array}$ \\
\hline Geodynamics & $\begin{array}{l}\text { Far-field effects of plate } \\
\text { collision, leading to } \\
\text { crustal-scale intraplate } \\
\text { compression and shortening } \\
\text { (e.g. Tianshan, South China) }\end{array}$ & $\begin{array}{l}\text { Continental collision and } \\
\text { subduction, resulting in } \\
\text { underthrusting of continental crust } \\
\text { after the closure of the oceanic } \\
\text { basin }\end{array}$ \\
\hline
\end{tabular}


The Early Paleozoic orogeny of the South China Block was most likely induced by a far-field effect of a collisional event, comparable with the Cenozoic intracontinental Tianshan orogen in NW China, the Neoproterozoic-Early Paleozoic intracontinental Alice Springs orogen in central Australia (Buick et al., 2008; Raimondo et al., 2014), the Mesozoic Qinling belt (Zhang GW et al., 2013; Dong YP et al., 2011) and the intracontinental Damara orogen in Namibia in the late stage of Neoproterozoic (Nex et al., 2001). In South China, the driving force of the Early Paleozoic intracontinental orogeny was likely resulted fror. 'the collision of the South China Block with a southern continent. A collision betwe $n t_{1}$ \& main part of the South China Block and Australia, a piece of which is suppc sed o be located in the Hainan island, has been proposed (Xu YJ et al., 2016). Hraver, the geological record for the Early Paleozoic arc magmatism and ophiolitic situ $\mathbf{1}$ is missing in the Hainan island. Another possibility would be to consider tl ^. $\mathrm{t}^{\mathrm{t}}$ e Early Paleozoic orogeny of South

China is a far-field consequence $c$. th 2 cullision between the North Vietnam or Viet-Lao Block with a southern continenı presently represented by the South Vietnam or Viet-Cambodia block (Faure t is 2018b).

\subsection{The "Late Paleozoic S, uut. China Ocean"}

\subsubsection{Upper Paleozo; _ä̈olarian cherts}

The Late Palec rolc geological setting of the South China Block has long been debated (Hsu et al., 1990; Zhao CH et al., 1995; Xiao and He, 2005). In the 1990's, Late Paleozoic radiolarians were reported from the Dexing-Shexian ophiolitic zone (Zhao CH et al., 1995), thus the previously defined Neoproterozic ophiolitic zone was changed into a Late Paleozoic suture zone derived from the Late Paleozoic South China Ocean (He KZ et al., 2000), which was inferred to be a branch of the Paleo-Tethys Ocean. Thus, some researchers adopted the view of a Late Paleozoic South China Ocean (Xiao and He, 2005), although others disagree (Li XH, 2000; Wang and Shu, 2001; Yang Q et al., 2005; Shu LS et al., 2006). The debates are 
focused on the Late Paleozoic depositional environment (Lin SF et al., 2018; Shu LS et al., 2018; Faure et al., 2018a) and the significance of the radiolarian-bearing cherts.

As marine plankton and radiolarians can live in the sea and ocean environments with different depths, and then be buried in sediments of various depths after their death and sinking. For example, the radiolarian might live in continental shelf of the East China Sea (Shu LS et al., 2006), and in shallow sea to the fjords of Norway (Caridroit M, 2012). After their death, most of the relics of radiolarians were accumulated in a shallow sea environment whereas a fe' may be transported to a deep-sea basin where the preservation is always mo e cifficult because of the dissolution of the radiolarian body during transportati $n$ tc the sea floor (Caridroit $M$, 2012). In addition, the Ce content has been preve to be useful for identifying depositional setting of radiolarian-bearing chets and most deep-sea radiolarians display an obvious Ce negative anomaly (St i r.iz d and Masuda, 1977).

The Late Paleozoic radiolarian be: ring cherts are widely distributed in South China. Permian radiolarian-bearing cherts have been identified in many places of the Yangtze Block. Radiolarian fos , ll, it seven generas and sixteen species have been identified from the Lower Pe rmla.n strata in the Lower Yangtze region (Yang Q et al., 2005). These chert la jars are mostly black and interlayered with Permian fusulina-bearing lime $\boldsymbol{n}_{\mathrm{n}}$ and arkose, suggesting that they were surely formed in a neritic environment ' $Y$ ang Q et al., 2005).

Geochemical cindracters of cherts within the Neoproterozoic Dexing-Shexian ophiolitic mélange zone indicate that these cherts were formed in an active continental margin (Li XH, 2000; Wang and Shu, 2001). From 1998 to 2002, Yang Q et al. (2005) studied 306 chert samples from the Neoproterozoic Dexing-Shexian ophiolitic mélange zone, concluding that no radiolarians could be observed, instead, Neoproterozoic acritarchs were identified from 74 out of 306 samples. Given these results on cherts, we consider that the previously inferred "Late Paleozoic radiolarian-bearing cherts" could either be incorrectly identified, or they were tectonically mixed with the Neoproterozoic ophiolitic mélanges during the Triassic or younger events. The true Neoproterozoic Dexing-Shexian ophiolite mélanges do not 
contain any radiolarian fossil (Yang Q et al., 2005; Shu LS et al., 2006).

\subsubsection{Upper Paleozoic stratigraphic sequences and depositional environment}

From the Late Devonian to Middle Triassic, the Yangtze, Jiangnan and Cathaysia depositional regions became identical, characterized by unified sedimentary assemblages of limestone, bioclastic limestone interlayered with sandstone and siltstone, enriched with coal layers, marine fossils and land flora fossils (Fig. 14; Shu LS et al., 2006, 2008b). The general stratigraphic sequences and rock assemblage may be described from upper to lower as follows.

The Upper Triassic strata are composed of conglor ier.te, sandy conglomerate, sandstone and coal-bearing siltstone. They overlie unc nformably the underlying pre-Triassic strata as shown in Pingxiang (Fig. 14). The Middle and Lower Triassic strata consist of siliceous mudstone, ammon $:$-bearing limestone, brecciated limestones, and gypsum beds. The Upp ${ }^{2}$ Fermian is composed arkose, plant fossils-bearing sandstone, carbonac o s s 'udstone interlayered with coal beds, fusulina-bearing limestone and marlite. The Lower Permian sequence consists of asphaltene-bearing limestone ar.u toiomite, radiolarian-bearing banded cherts and fusulina-bearing limestone. The Carboniferous is a sequence of limestone, dolomitic limestone interlayered with tolomite and marlite, enriched in brachiopoda, coral and fusulina fossils. The L'ner-Middle Devonian strata are the assemblages of conglomerate, sanc ${ }^{t} \mathrm{on}_{\mathrm{m}}$ and mudstone, enriched plant, fish and fusulina fossils and overlie unconformabıy the underlying pre-Devonian strata.

The aforementioned strata sequences and lithotectonic assemblages indicate that the upper Paleozoic sedimentary rocks in South China were formed in a coastal marsh-tidal and flat-shelf neritic environment (Figs. 9 and 14). They reflect a true paleogeographic evolution from the Late Devonian short-term continental onshore, via Early Carboniferous to Early Permian long-term neriticand and Middle Permian short-term uplifting and subsidence, then Early to Middle Triassic neritic-coastal environment. Finally, a Late Triassic crustal uplift took place in the whole South 
China, following the end of marine setting and beginning of the lake and river delta environment as a response to the closure of the Paleo-Tethys Ocean in the Early Mesozoic. These conclusions are consistent with our field-investigations

Actually, no mappable deep-sea (>3,000 m depth) sediment existed during the Late Paleozoic to Early Mesozoic times (Shu LS et al., 2006, 2008b, 2009). The available geological data and micro-paleontological results disagree with the hypothesis of a "Late Paleozoic South China Ocean".

\subsection{Geodynamics of Mesozoic magmatism in the southe: ${ }^{-}$coastal region}

Undoubtedly, the Mesozoic magmatism is widesp ead in the southeast China coastal region (Fig. 16) with ages ranging from the $\mathrm{I}$ a. $\cdot \mathrm{T}$ rassic to Cretaceous and up to $-30-40 \%$ of the exposure cropping out over $121, \Upsilon 0 \mathrm{v} \mathrm{km}^{2}$ (Zhou XM et al., 2006). Several models have been proposed to explain the giodynamic cause of this general Mesozoic magmatism, essentially baser: n petrological, geochronological and geochemical studies (e.g. Hsu et al., 199 J; Zhou and Li., 2000; Li and Li, 2007; Chen $\mathrm{CH}$ et al., 2008; Faure et al., 26⿳⺈a, Chu et al, 2019). Nevertheless, each of them presents some weaknesses on se ve ra fundamental questions, such as the petrogenesis and related regional tectonir atting of the magmatism. For instance, the mantle plume model was proposed acco. ding to the circular distribution of bimodal (mafic-acidic) volcanic rocks dat d .t 130-120Ma and 100-90Ma, which are dominated by andesite-dacite-rhyon e suites, along with a few basaltic rocks (Xie GQ et al., 2001; Mao JW et al., 1998, 2013). However, the Late Triassic-Early Jurassic volcanism is rarely recorded in South China. Moreover, mantle plume is considered as a short duration event, usually less than 10 Ma (Campbell and Griffiths 1990). Whereas the Mesozoic magmatism in South China lasted for $~ 130$ Ma.

Based on the gradually temporal and spatial distribution of granitoids from inland (older) to costal area (younger) as well as the rough parallel relationship between the regional NE-trending fold-fault system and continental margin, several reseachers have proposed a model of the low-angle flat slab subduction and 
subsequent roll back of subducting slab (Zhou and Li, 2000; Zhou XM et al., 2006; Li and Li, 2007; Jiang YH et al., 2015). However, neither reliable ophiolite, nor arc-type magmatism has been found to prove the existence of oceanic slab subduction. Moreover, numerous recent geochronological studies show that Late Jurassic plutons are widely distributed in the Southeast China region with a planar distribution in map view (Liu Q et al., 2012, Cui JJ et al., 2013, Zhang Y et al., 2015).

Given the E-W trending OIB-like mafic rock series developed from 180 to 110 $\mathrm{Ma}$ in the interior of the Cathaysia Block, Chen $\mathrm{CH}$ et al. (ग908) considered that they were due to the Indosinian post-orogenic magmatism. Bu the Indosinian orogeny was terminated in the Late Triassic (ca. $220 \mathrm{Ma}$ ), much ol ler $\mathrm{l}$ ian the Jurassic mafic rock series (ca. $175 \mathrm{Ma}$ ). The E-W trending mas a atım during 180-160 Ma was considered as a product of intracontinental rifting Deng P et al., 2004; Shu et al., 2009). Moreover, the Jurassic extension- ( $r$ sh ortening-related E-W-trending faults are not observed in the magmatic zor e. The large-scale extension was probably triggered by roll back of the Palao-Paciı̈c subduction. Another hypothesis concerns the intracontinental crustal subd ic i nn (Faure et al., 2016a). This model suggests that a Triassic oceanward contirenta' subduction was accommodated by a large-scale décollement within the $\mathrm{C}$-thà ${ }^{\text {v }}$ sia Block as that recognized in the Xuefeng Mts. (Chu et al., 2012a). Nev heiss, the contemporary sedimentary basins are lacking. Furthermore, the sbaucted cold continental crust would hinder the thermal conduction from the mantle to lower crust.

In brief, no existing model can satisfactorily explain the features of the Mesozoic magmatism, consequently the tectonic setting and geodynamics for the Mesozoic magmatism in the Southeast China region are still enigmatic. An integrated petrological, geochemical, rock magnetic and paleomagnetic study should be a good approach (Manning and Elmore, 2015; Zhang Y et al., 2018).

\section{Conclusions}

Synthesizing aforementioned analyses on the geological and tectonic evolution of 
the South China Block, the following guidelines seem to be clear.

1. The South China Block was formed by the assembly of the Yangtze and Cathaysia blocks in the Neoproterozoic. It experienced a long-term tectonic evolution, including (a) the early to middle Neoproterozoic subduction-collision (at 980-840 Ma) and rifting (at 810-760 Ma), (b) the Early Paleozoic intracontinental orogeny, granitic magmatism and migmatization (at 440-420 Ma), (c) the Early Mesozoic intracontinental reworking and granitic magmatism (at 240-220), and (d) the Late Mesozoic back-arc volcanism and magma intrusion (at $199-100 \mathrm{Ma}$ ). The tectonic process was constrained and affected by the closures of he Paleo-South China, Proto-Tethys, Paleo-Tethys and Paleo-Pacific oceans.

2. The Cathaysia Block has a pre-Late $\mathbf{T}_{\mathbf{O}_{1} \text {. }}$ an basement dominated by Neoproterozoic rocks. Although some Paleoprotrro nic magmatic rocks are reported,

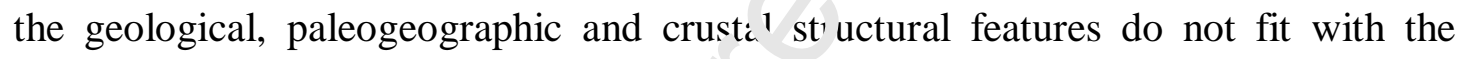
concept of the Cathaysia Oldland. $\mathbf{J}+$ th $: 900-840$ Ma period, the subduction of the Paleo-South China Ocean benerth the rangtze Block resulted in the South China trench, volcanic arc and back-z ic :asin system. The collision of the Cathaysia and Yangtze blocks during 8ศ)-8ఓ? Ma yielded regional metamorphism, ductile deformation and magm ${ }^{\text {itis }}$, along the southeast Yangtze margin, forming the Jiangnan Orogenic P.: vilortly afterwards, continental rifting during 810-760 Ma occurred nearby the ${ }_{1}$ revious suture zone.

3. The initial formation of the Proto-South China Continent likely took place in the interval of 825-800 Ma, marked by a regional-scale anglar unconformity. During the Cryogenian to Late Ordovician interval, the Cathaysia Block was in a stable neritic to slope depositional environment, dominated by graptolite-bearing mudstone and sandstone sequences. In the period of 460-400 Ma, as response to the closure of the remote Proto-Tethys Ocean, intense ductile deformation and S-type granitic magmatism took place and formed the South China intracontinental orogenic belt. This orogen shows distinctive characteristics and is comparable with several 
intracontinental orogens worldwide. The Early Paleozoic South China intracontinental orogeny was most likely a result of far-field effects related to a collisional event in the south of the South China Block.

4. During the Cryogenian to Middle Jurassic, neither trans-lithosphere faulting nor mantle-derived magmatism was documented. In the Early-Middle Jurassic (ca. 180-150 Ma), with the tectonic transition from the E-W-trending Paleo-Tethys regime to the NE-SW trending Paleo-Pacific one, the Southeast China region evolved into a part of the western Paleo-Pacific active continental margin. The Late Mesozoic back-arc extension with a peak age at 140-110 Ma result 2 ? in the formation of the South China basin-and-range tectonics.

\section{Acknowledgements}

This paper has benefited from the perceptive co cm $_{\downarrow}$ nts of Prof. Franz Neubauer, Dr. Feng Guo and an anonymous reviewer. $W^{/} \in \mathrm{x}^{\mathrm{r}}$ ress our gratitude to Prof. Neubauer for his constructive suggestions, $\mathrm{E}^{r}$ glis $\Omega$ and extensive annotations throughout the manuscript, which led to major : mproveınents of the manuscript. Profs. Ren Jishun, Wang Dezi, Xu Zhiqin, Dr. Lil $\mathbf{J}_{\mathfrak{i}}{ }^{\prime}{ }^{h}$ uo and Dr. Gou Yiren are heartly thanked for their constructive suggestic:s and help in this study. We also thank Profs. Yang Minggui, Chen Xiangyun anc Lou Fasheng for their helps in the field-investigations. This study was finar - a $^{1}{ }^{1} \mathrm{y}$ supported by the National Natural Science Foundation of China (grants. 417\%?04 and 41972238) and the National Key R \& D Program of China (No. 2016YFC0600202). The partial help from LABEX VOLTAIRE (ANR 10 - LABX - 100 - 01), Région Centre ARGON, and EQUIPEX PLANET (ANR-11-EQPX-0036) are also appreciated.

\section{References}

Billlings M P. 1972. Structural Geology. New Jersey: Prentice Hall, Inc. Englewood Cliffs, 286p. doi.org/10.1029/2018JB015547

Buick I S, Hand M, Williams I S, Mawby J, Miller J A, Nicoll B. 2005. SHRIMP constraints on the timing of deposition of protoliths to the Harts Range Metamorphic Complex (Arunta Inlier): tectonic implications. J. Geol. Soc. London, 162: 777-787. https: 
//doi.org/10.1111/j.1525-1314.2008.00794.x

Campbell, I. H., Griffiths, R. W., 1990. Implications of mantle plume structure for the evolution of flood basalts. Earth and Planetary Science Letters 99(1-2), 79-93. doi.org/10.1016/0012-821X(90)90072-6

Caridroit, M., 2012. Radiolaria and tectonics in Japan and Thailand. In: Chen Y. editor, Orleans: International Conference on Tectonics of Asia, 23-25.

Cawood, P.A., Zhao, G.C., Yao, J.L., Wang, W., Xu, Y.J., Wang, Y. J., 2018. Reconstructing South China in Phanerozoic and Precambrian supercontinents. Earth-Science Reviews 186, 173-194. doi.org/10.1016/j.earscirev.2017.06.001

Cawood, P. A., Wang, W., Zhao, T., Xu, Y., Mulder, J. A., Pisarevsky, S., Zhang, L., Gan, C.S., He, H.Y., Liu, H.C., Qi, L., Wang, Y.J., Yao, J.L., Zhao, G.C., 'hou, M.F., Zi, J.W., 2020. Deconstructing South China and consequences for recr nstrı sting Nuna and Rodinia. Earth-Science Reviews, 103169.

Carter, A., Roques, D., Bristow, C., 2001. Understandi-g, iviesozoic accretion in Southeast Indosinian: Significance of Triassic thermotecto ism. (Indosinian orogeny) in Vietnam. Geology 29, 211-214. doi.org/10.1130/0091-7613/200: '029

Charvet, J., 2013. The Neoproterozoic-early $\mathrm{Pa} e \mathrm{ec} \mathrm{c}^{\circ} \mathrm{c}$ tectonic evolution of the South China Block: An overview. Journal of Asian Ear.' Sciences 74, 198-209.

Charvet, J., Lapierre, H., \& Yu, Y. W., 19 4. $($ eodynamic significance of the Mesozoic volcanism of southeastern China. Journal of ¿ vutheast Asian Earth Sciences 9(4), 387-396. doi.org/10.1016/0743-9547(94)90แ-7 -7

Charvet, J., Shu, L. S., Shi, Y. S., C ur, ... Z., \& Faure, M., 1996. The building of south China: collision of Yangtze and ( at. 'vsia blocks, problems and tentative answers. Journal of Southeast Asian Earth Sci. nct. 13 (3-5), 223-235. doi.org/10.1016/0743-9547(96)00029-3

Charvet, J., Shu, L. S., Fau - .1., Choulet, F., Wang, B., Lu, H.F., \& Breton, N.L., 2010. Structural developmen $r_{i}$ the Early Paleozoic belt of South China: genesis of an intracontinenta1 Jog n. Journal of Asian Earth Sciences, 39, 923-330. doi.org/10.1016/j.js aes.2010.03.006

Chen, C. H., Lee, C. Y., \& Shinjo, R., 2008. Was there Jurassic paleo-Pacific subduction in South China? Constraints from ${ }^{40} \mathrm{Ar} /{ }^{39} \mathrm{Ar}$ dating, elemental and $\mathrm{Sr}-\mathrm{Nd}-\mathrm{Pb}$ isotopic geochemistry of the Mesozoic basalts. Lithos 106, 83-92. doi.org/10.1016/j.lithos.2008.06.009

Chen, G. H., Shu, L. S., Shu, L. M., Zhang, C., \& Ouyang, Y. P., 2015. Geological characteristics and mineralization setting of the Zhuxi tungsten (copper) polymetallic deposit in the Eastern Jiangnan Orogen. Science China: Earth Sciences 59, 803-823. doi.org/10.1007/s11430-015-5200-9

Chen, J. F., Foland, K. A., Xing, F. M., Xu, X., \& Zhou, T. X., 1991. Magmatism along the southeast margin of the Yangtze block: Precambrian collision of the Yangtze and Cathaysia blocks of China. Geology 19, 815-818. doi.org/10.1130/0091-7613(1991)0192.3.CO;2

Chen, X., Wang, D., Wang, X. L., Gao, J. F., Shu, X. J., Zhou, J. C., \& Qi, L., 2014. Neoproterozoic chromite-bearing high-Mg diorites in the western part of the Jiangnan orogen, 
southern China: Geochemistry, petrogenesis and tectonic implications. Lithos 200-201, 35-48. doi.org/10.1016/j.lithos.2014.04.007

Chen, X., Zhang, Y. D., Fan, J. X., Tang, L., \& Sun, H. Q., 2012. Onset of the Kwangsian Orogeny as evidenced by biofacies and lithofacies, Science in China (Series D) 55, 1592-1600. doi.org/10.1007/s11430-012-4490-4

Chu, Y., Faure, M., Lin, W., \& Wang, Q. C., 2012a. Early Mesozoic tectonics of the South China Block: Insights from the Xuefengshan intracontinental orogen. Journal of Asian Earth Sciences 61, 199-220. doi.org/10.1016/j.jseaes.2012.09.029

Chu, Y., Faure, M. Lin, W., Wang, Q. C., \& Ji, W. B., 2012b. Tectonics of the Middle Triassic intracontinental Xuefengshan Belt, South China: New insights from structural and chronological constraints on the basal décollement zone. International Journal of Earth Sciences 101(8), 2125-2150. doi.org/10.1007/s00531-012-078i )

Chu, Y., Lin, W., Faure, M., Xue, Z., Ji, W., Feng, Z. 2019. Cret.ct 'Is episodic extension in the


China. Tectonics, 38. doi.org/10.1029/2019TC005516

Cui, J. J., Zhang, Y. Q., Dong, S. W., Jahn, B. M., Xu, X. ? , \& Ma, L. C., 2013. Zircon U-Pb geochronology of the Mesozoic metamorphic ro: 's al d granitoids in the coastal tectonic zone of SE China: Constraints on the timing of 'ate : Mesozoic orogeny. Journal of Asian Earth Sciences 62, 237-252. doi.org/10.1016, 1.i ec as.2012.09.014

Cui, X., Zhu, W. B., Fitzsimons, I. C. W., Waı.: X., Lu, Y. Z. \& Wu, X. H., 2017. A poassible transition fromisland arc to continer 11 a' -magmatism in the eastern Jiangnan Orogen, South China: Insights from a Neoproterozoic ' $870-860 \mathrm{Ma}$ ) gabbroic-dioritic complex near the Fuchuan ophiolite. Gondwana Resew rh 46, 1-16. doi.org/10.1016/j.gr.2017.02.012

Deng, H., Peng, S. B., Polat, A. 1., Kı sk ,, T., Jiang, X. F., Han, Q. S., Wang, L., \& Huang, Y., 2017. Neoproterozoic IAT ir aru : on into Mesoproterozoic MOR Miaowan Ophiolite, Yangtze Craton: Evidence for $\mathrm{e}$ olv.'g tectonic settings. Precambrian Research 289, 75-94. doi.org/10.1016/j.precan ${ }^{*}{ }^{\circ} . \angle 016.12 .003$

Deng, P., Shu, L. S., \& Xiao, I H., 2002. A Study on the Tectonic Basement of the Late Mesozoic Igneous Rock in Sol heastern China. Geological Journal of China Universities 8(2), 169-179. doi.org/le 1080/12265080208422884

Deng, P., Shu, L. S., ru, X. Q., Sun, Y., Wang, B. \& Tan, Z. Z., 2004. Early-Middle Jurassic Basins and Features of Volcanic rocks in the Western Fujian-Southern Jiangxi Region. Acta Petrologica Sinica 20(3), 521-532. doi.org/10.1016/j.sedego.2004.01.009

Deng, T., Xu, D., Chi, G., Zhu, Y., Wang, Z., Chen, G., Li, Z. H., \& Zhang, J. L., 2019. Revisiting the ca. 845-820-Ma S-type granitic magmatism in the Jiangnan Orogen: new insights on the Neoproterozoic tectono-magmatic evolution of South China. International Geology Review 61(4), 383-403. doi.org/10.1080/00206814.2018.1426054

Dong, Y.P., Zhang, G.W., Hauzenberger, C., Neubauer, F., Yang, Z., Liu, X.M., 2011. Palaeozoic tectonics and evolutionary history of the Qinling orogen: evidence from geochemistry and geochronology of ophiolite and related volcanic rocks. Lithos 122, 39-56.

Dong, Y., Santosh, M., 2016. Tectonic architecture and multiple orogeny of the Qinling Orogenic Belt, Central China. Gondwana Research 29(1), 1-40. 
Dong, Y., Sun, S., Yang, Z., Liu, X., Zhang, F., Li, W., Chen, B., \& He, D., 2017. Neoproterozoic subduction-accretionary tectonics of the South Qinling Belt, China. Precambrian Research 293, 73-90. doi.org/10.1016/j.precamres.2017.02.015

Faure, M., Caridroit, M. \& Charvet, J., 1986. Tectonic evolution of the late Jurassic or Early Yenshan orogeny of SW Japan: New structural data and synthesis. Tectonics 5, 1089-1114. doi.org/10.1029/tc005i007p01089

Faure, M., Marchadier, Y., \& Rangin, C., 1989. Pre-Eocene synmetamorphic structure in the Mondoro-Romblon-Palawan area, west Philippines, and implications for the history of Southeast Asia. Tectonics 8(5), 963-979. doi.org/10.1029/TC008i005p00963

Faure M, Natal'in B.A., 1992. The Geodynamic evolution of the Eastern Eurasian margin in Mesozoic times.Tectonophysics, 208, 397-411.

Faure M., Sun Y., Shu L., Charvet J. 1996. Extensional tectonics wı.' in a subduction type orogen. The case study of the Wugongshan dome (Jiangxi Provinc, Thina). Tectonophysics, 263, 77-107.

Faure M., Lin W., Shu L., Sun Y., Schärer U. 1999. Tectoni `s of the Dabieshan (E. China) and possible exhumation mechanism of ultra high-pressure I rks. Terra Nova, 11, 251-258.

Faure M., Lin W., Schärer U., Shu L., Sun Y., Arna d N 2003. Continental subduction and exhumation of UHP rocks. Structural and geochrr nolo ${ }_{\varepsilon}{ }^{i}$ cal insights from the Dabieshan (E. China). Lithos, 70, 213-241.

Faure, M., Shu, L. S., Wang, B., Charvet. I., Thoulet, F., \& Monié, P., 2009. Intracontinental subduction: a possible mechanism fr th $f$ Early Palaeozoic Orogen of SE China. Terre Nova, 21, 360-368. doi.org/10.1111/j.1365-31 : 2009.00888.x

Faure M., Lepvrier C., Nguyen VV, Vu VT, Lin W. Chen Z. 2014. The South China Block-Indochina collision: whe :, $N_{1}, \mathrm{n}$, and how? J. Asian Earth Sciences, 79, 260-274.

Faure, M., Lin, W., Yang, C., Ler vrı - C., 2016a. Triassic tectonics of the southern margin of the South China Block. C. R. jeos i. 328, 5-14.

Faure, M., Lin, W., Chu, Y., a Lepvrier, C., 2016b. Triassic tectonics of the Ailaoshan Belt (SW China): early Triassir c. ${ }^{11}$, sion between the South China and Indochina Blocks, and Middle Triassic ntri ont nental shearing. Tectonophysics 683, 27-42. doi.org/10.1016/j.te to.2016.06.015

Faure, M., Charvet, J., $\alpha$ Chen, Y., 2018a. Forum Comments on: Appalachian-style multi-terrane Wilson cycle model for the assembly of South China. Geology 46, e446. doi.org/10.1130/G40213C.2

Faure, M., Nguyen, V. V., Thu Hoai, L. T., \& Lepvrier, C., 2018b. Paleozoic or Early-Middle Triassic collision between the South China and Indochina Blocks: The controversy resolved? Structural insights from the Kon Tum massif (Central Vietnam). Journal of Asian Earth Sciences 166, 162-180. doi.org/10.1016/j.jseaes.2018.07.015

Gan, X. C., Li, H. M., \& Sun, D. Z., 1993. Geochronological study on the Precambrian metamorphic basement in northern Fujian. Geology of Fujian 12(1), 17-32.

Gardner, C. J., Graham, I. T., Belousova, E., Booth, G. W., \& Greig, A., 2017. Evidence for Ordovician subduction-related magmatism in the Truong Son terrane, SE Laos: implications for Gondwana evolution and porphyry $\mathrm{Cu}$ exploration potential in SE Asia. Gondwana 
Research 44, 139-156. doi.org/10.1016/j.gr.2016.11.003

Gao, J., Klemd, R., Long, L. L., Xiong, X. M., \& Qian, Q., 2009. Adakitic signature formed by ractional crystallization: An interpretation for the Neo-Proterozoic meta-plagio granites of the NE Jiangxi ophiolitic mélange belt, South China. Lithos 110, 277-293. doi.org/10.1016/j.lithos.2009.01.009

Gao, L. Z., Chen, J., Ding, X. Z., Liu, Y. R. Zhang, C. H., \& Zhang, H., 2011. Zircon SHRIMP $\mathrm{U}-\mathrm{Pb}$ dating of the tuff bed of Lengjiaxi and Banxi Groups, northeastern Huna: constraints on the Wuling movement. Geology Belletin of China, 30(7), 1001-1008.

Gao, S., \& Zhang, B., 1990. The discovery of Archean TTG gneisses in northern Yangtze craton and their implications. Earth Science 15, 675-679.

Gao, S., Yang, J., Zhou, L., Li, M., Hu, Z. C., Guo, J. L., Yuan, H. L., \& Gong, H. J., 2011. Age and growth of the Archean Kongling Terrain, South Chin c with emphasis on $3.3 \mathrm{Ga}$

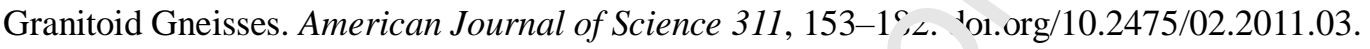

Guo, F., Li, H.X., Fan, W.M., Li, J.Y., Zhao, L., Huang, M.W 'w, W.L., 2015. Early Jurassic subduction of the Paleo-Pacific Ocean in NE China: $x$ trols gic and geochemical evidence from the Tumen mafic intrusive complex. Lithos 224-2 - : 46-60.

Guo, F., Wu, Y.M., Zhang, B., Zhang, XB., Zhao, L Lia ), J., 2021. Magmatic responses to Cretaceous subduction and tearing of the paleo-'acis: Plate in SE China: An overview. Earth-Science Reviews 212, 103448.

Gilder, S. A., Keller, G. R., \& Luo, M., 1991. 7astern Asia and the western Pacific timing and spatial distribution of riftin. n China. Tectonophysics 197, 225-243. doi.org/10.1016/0040-1951(91)90043-K

Gilder, S. A., Gill, J., \& Coe, R. S., 199u. Isotopic and paleomagnetic constrains on the Mesozoic tectonic evolution of South C ir a. Journal of Geophysical Research: Solid Earth 101,

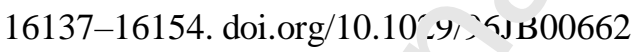

Gilder, S. A., Leloup, P. H., \&. Cou tillot, V., 1999. Tectonic evolution of the Tancheng-Lujiang (Tan-Lu) fault via Mia."e Triassic to Early Cenozoic Paleomagnetic data. Journal of Geophysical Researrh: ¿nl d Earth 104(B7), 15365-15390. doi.org/10.1029/1999JB900123

Grabau, A.W., 192' S atig aphy of China: Part I, Paleozoic and older (pp. 1-6). Peking: The Geological Survey , $f$ Agriculture and Commerce, 528p.

Guo, L. H., \& Gao, R. (2018). Potential-field evidence for the tectonic boundaries of the central and western Jiangnan Orogenic Belt in South China. Precambrian Research 309, 45-55. doi.org/10.1016/j.precamres.2017.01.028

Guo, L. Z., Yu, J. H., \& Shi, Y. S., 1965. Main features of tectonic development of the Caledonian period folded geosyncline, South China. Beijing: Science Press, 165-183. (in Chinese with English abstract)

Guo, L. Z., Shi, Y. S., Lu, H. F., \& Ma, R. S., 1989. The pre-Devonian tectonic patterns and evolution of South China. Jounal of Southeast Asian Earth Sciences 3(1-4), 87-93. doi.org/10.1016/0743-9547(89)90012-3

Guo, L. Z., Shu, L. S., Lu, H. F., Shi, Y. S., Ma, R. S., Zhang, Q. L., Wang, L. S., \& Jia, D., 2000. A synthetical review on research advances on the terrane tectonics in China. Journal of Nanjing University (Natural Sciences) 36(1), 1-17. 
Hacker, B. R., Ratschbacher, L., Webb, L., Ireland, T., Walker, D., \& Dong, S. W., 1998. U/Pb zircon ages constrain the architecture of the ultrahigh-pressure Qinling-Dabie Orogen, China. Earth and Planetary Science Letters 161, 215-230. doi.org/10.1016/S0012-821X(98)00152-6

Han, Q. S., Peng, S. B., Kusky, T., Polat, A., Jiang, X. F., Cen, Y., Liu, S. F., \& Deng, H., 2017. A Paleoproterozoic ophiolitic mélange, Yangtze craton, South China: Evidence for Paleoproterozoic suturing and microcontinent amalgamation. Precambrian Research 293, 13-38. doi.org/10.1016/j.precamres.2017.03.004

Han, Z. R., Yang, Z. Y., Tong, Y. B., Jing, \& X. Q., 2015. New paleomagnetic results from late Ordovician rocks of the Yangtze Block, South China, and their paleogeogragphic implications. Journal of Geophysical Research: Solid Earth 120 (7), 4759-4772. doi.org/ 10.1002/2015JB012005

He, K. Z., Nie, Z. T., \& Zhao, C. H., 2000. Discovery of the Lat $\mathrm{r}^{\prime}{ }^{\prime} \mathrm{eozoic}$ radiolarian fossils in northeastern Jiangxi. Geoscience 14, 1-10.

Hsu, K. J., Sun S., \& Li, J. L., 1990. Tectonics of South China Ke to understanding West Pacific geology. Tectonophysics 183, 9-39. doi.org/10.1016/04 ר-1951(90)90186-C

Huang, B.C., Yan, Y.G., Piper, J.D.A., Zhang, D.H Yi, Z.Y., You, S., Zhou, T.H., 2018. Paleomagnetic constraints on the paleogeograpr $y$ or the East Asian blocks during late Paleozoic and Early Mesozoic ti.nis. Earth-Science Reviews 186, https://doi.org/10.1016/j.earscirev.2018 02:.74

Huang, J. Q., 1945. On Major Tectonic Fr ms ff China (Ser. A. 20). Nanjing: Geological Memoirs, 165p. (in Chinese with English abstract,

Ichikawa, K., Mizutani, S., \& Hara, I., , 190. Pre-Cretaceous terrances of Japan. In: Pre-Jurassic evolution of Eastern Asia (IGCI 2`4 . Japan: Osaka Publication, 413p.

Jiang, Y. H., Wang, G. C., Liu L., N1, C. Y., Qing, L., \& Zhang, Q., 2015. Repeated slab advance-retreat of the P: laeu Pacific plate underneath SE China. International Geology Review 57, 472-491. dol. $\cdot$ rg/ i0.1080/00206814.2015.1017775

Jing, X. Q., Yang, Z. Y., TOH ' I. B., \& Han, Z. R., 2015. A revised paleomagnetic pole from the mid-Neoproter $\mathrm{zo}^{-}$- L antuoFormation in the Yangtze block and its paleogeographic implications. Preca. vbrian Research 268, 194-211. doi.org/10.1016/j.precamres.2015.07.007

Kato, K., \& Saka, Y., _u03. Kurosegawa Terrane as a Transform Fault Zone in Southwest Japan. Gondwana Research 6 (4), 669-686. doi.org/10.1016/S1342-937X(05)71016-9

Kato, K., \& Saka, Y., 2006. New model for the Early Cretaceous development of SW Japan based on basic rocks of the Chichibu composite Terrane. Geosciences Journal 10 (3), 275-289. doi.org/10.1007/BF02910370

Keppie, D. F., 2015. How the closure of paleo-Tethys and Tethys oceans controlled the early breakup of Pangaea. Geology 43, 335-338.

Lapierre, H., Jahn, B. M., Charvet, J., \& Yu, Y. W., 1997. Mesozoic felsic arc magmatism and contrnental olivine tholeiites in Zhejiang Province and their relationship with tectonic activity in SE China. Tectonophysics 274, 321-338. doi.org/10.1016/s0040-1951(97)00009-7

Lepvrier, C., Maluski, H., Nguyen, V. V., \& Van Tich, V., 1997. Indosinian NW-trending shear zones within the Truong Son belt (Vietnam) ${ }^{40} \mathrm{Ar}-{ }^{39} \mathrm{Ar}$ Triassic ages and Cretaceous to 
Cenozoic overprints. Tectonophysics 283, 105-127. doi.org/10.1016/S0040-1951(97)00151-0

Lepvrier, C., Maluski, H., Van Tich, V., Leyreloup, A. F., Thi, P. T., \& Van Vuong, N., 2004. The

Early Triassic Indosinian orogeny in Vietnam (Truong Son Belt and Kontum Massif); implications for the geodynamic evolution of Indochina. Tectonophysics 393(1), 87-118. doi.org/10.1016/j.tecto.2004.07.030

Li, H. B., Jia, D., Wu, L., Zhang, Y., \& Yin, H. W., 2013. Detrital zircon provenance of the Lower Yangtze foreland basin deposits: constraints on the evolution of the early Palaeozoic Wuyi-Yunkai orogenic belt in South China. Geological Magazine 150(6), 959-974. doi.org/10.1017/S0016756812000969

Li, J. H., Dong, S. W, Zhang, Y. Q., Zhao, G. C., Johnston, S. T., Cui, J. J., \& Xin, Y. J., 2016. New insights into Phanerozoic tectonics of south China: Part 1, polyphase deformation in the Jiuling and Lianyunshan domains of the central Jiangnan O1, sen. Journal of Geophysical Research: Solid Earth 121, 1-33. doi.org/10.1002/2015JB01? is?

Li, J. H., Zhang, Y. Q., Zhao, G. C., Johnston, S. T., Dong, S. W intiony, K., Daniel, P., \& Sun, H.S., 2017. New insights into Phanerozoic tectonics of S, 'ith ' thina: Early Paleozoic sinistral and Triassic dextral transpression in the east Wuyishang nd Chencai domains, NE Cathaysia. Tectonics 36(5), 819-853. doi.org/10.1002/2016TC 1044 i1

Li, J. H., Cawood, P. A., Ratschbacher, L., Zhang, Y Q., Tong, S. W., Xin, Y. J., Yang, H. \& Zhang, P., 2020. Building Southeast China $n$ nt late Mesozoic: Insights from alternating episodes of shortening and extension ai ng the Lianhuashan fault zone. Earth-Science Reviews 201, 103056.

Li, J. Y., Wang, X. L., Zhang, F. F., Zhou, X. .' , \& Shu, X. J., 2016. A rhythmic source change of the Neoproterozoic basement $m^{\prime} \uparrow$-sedimentary sequences in the Jiangnan Orogen: Implications for tectonic evol iti $\mathrm{s}$ on the southeastern margin of the Yangtze Block. Precambrian Research 280, +6- \%). doi.org/10.1016/j.precamres.2016.04.012

Li, S. G., 1962. Outline of g ol ז.echanics. Beijing: Geological Publishing House, 133p. (in Chinese with English abs, " $\mathrm{ac}$ ) .

Li, S. Z., Santosh, M., \& Jahr, B. M., 2012. Evolution of Asian continent and its continental margins. Jourr al c c ${ }^{\circ}$ Asi $n$ Earth Sciences 47, 1-4. doi.org/10.1016/j.jseaes.2012.02.001

Li, W. X., \& Li, X. H., 2003. Adakitic granites within the NE Jiangxi ophiolites, South China: geochemical anu $\mathrm{Nd}$ isotopic evidence. Precambrian Research 122, 29-44. doi.org/10.1016/S0301-9268(02)00206-1

Li, W. X., Li, X. H., \& Li, Z. X., 2005. Neoproterozoic bimodal magmatism in the Cathaysia Block of South China and its tectonic significance. Precambrian Research 136, 51-66. doi.org/10.1016/j.precamres.2004.09.008

Li, W. X., Li, Z. X., Li, X. H., \& Lou F. S., 2008. Obduction-type granites within the NE Jiangxi ophiolite: implications for the final amalgamation between the Yangtze and Cathaysia Blocks. Gondwana Research 13, 288-301. doi.org/10.1016/j.gr.2007.12.010

Li, X. H., 1998. The SHRIMP U-Pb zircon geochronology of Paleo-Proterozoic plagioclassamphibolite in the Zhejiang-Fujian area. Journal of Geochemistry 27(4), 327-334.

Li, X. H. 2000. Geochemistry of the Late Paleozoic radiolarian cherts within the NE Jiangxi ophiolite melange and its tectonic significance. Science in China (Series D) 43(6), 617-624. 
doi.org/10.1007/BF02879505

Li, X. H., Zhou, G. Q., Zhao, J. X., Fanning, C. M., \& Compston, W., 1994. SHRIMP ion microprobe zircon $\mathrm{U}-\mathrm{Pb}$ age and $\mathrm{Sm}-\mathrm{Nd}$ isotopic characteristics of the NE Jiangxi ophiolite and its tectonic implications. Chinese Journal of Geochemistry 13, 317-325. doi.org/10.1007/BF02838521

Li, X. H., Li, Z. X., Ge, W., Zhou, H. B., Li, W. X., Liu, Y., \& Wingate, M. T. D., 2003. Neoproterozoic granitoids in South China: crustal melting above a mantle plume at ac. 825Ma? Precambrian Research 122, 45-83. doi.org/10.1016/s0301-9268(02)00207-3

Li, X. H., Li, Z. X., Li, W. X., \& Wang, Y., 2006. Initiation of the Indosinian Orogeny in South China: Evidence for a Permian Magmatic Arc on Hainan Island. The Journal of Geology 114(3), 341-353. doi.org/10.1086/501222

Li, X. H., Li, W. X., Li, Z. X., \& Liu Y., 2008. 850-790 Ma bimoa ' volcanic and intrusive rocks in northern Zhejiang, South China: A major episode of contir $\mathrm{cm} \cdot \mathrm{l} \mathrm{rt}$ magmatism during the breakup of Rodinia. Lithos 102, 341-357. doi.org/10.1016/i 11: 2007.04.007

Li, X.H., Li, W.X., Li, Z.X., Lo, C.H., Wang, J., Ye, M.F., Yar g, Y.H., 2009. Amalgamation between the Yangtze and Cathaysia Blocks in South Ch ' zircon ages, geochemistry and $\mathrm{Nd}-\mathrm{Hf}$ isotop of the Shuangxiwu volcanic rocks. Precambrian Research 174, 117-128. doi.org/10.1'J16/J. .recamres.2009.07.004

Li, Z. X., Li, X. H., \& Kinny P. D., 1999. The bre k' p of Rodinia: did it start witha mantle plume beneath South China? Earth and Planetary Science Letters 173, 171-181. doi.org/10.1016/S0012-821X(99)00 +0- .

Li, Z. X., Li, X. H., Kinny P. D., Wang, J., .'hang, S., \& Zhou, H.W., 2003. Geochronology of Neoproterozoic syn-rift magmatism : $\eta$ the Yangtze Craton, South China and correlations and correlations with other continer s: e : dence for a mantle super plume that broke up Rodinia. Precambrian Research 122, so- 1()y. doi.org/10.1016/S0301-9268(02)00208-5

Li, Z. X., Evans, D. A. D., \& 7. any, S., 2004. A 90 spin on Rodinia: possible causal links between the Neoproterozoic super nni.nent, superplume, true polar wander and low-latitude glaciation. Earth and Ditnetary Science Letters 220, 409-421. doi.org/10.101‘/S( 112- 321X(04)00064-0

Li, Z. X., \& Li, X. F. 2007. Formation of the 1300-km-wide intracontinental orogen and postorogenic magınatic province in Mesozoic South China: A flat-slab subduction model. Geology 35, 179-182. doi.org/10.1130/G23193A.1

Li, Z. X., Bogdanova, S. V., Collins, A. S., Davidson, A., De Waele, B., Ernst, R. E., Fitzsimons, I. C. W., \& Fuck, R. A., 2008. Assembly, configuration, and break-up history of Rodinia: a synthesis. Precambrian Research 160, 179-210. doi.org/10.1016/j.precamres.2007.04.021

Li, Z. X., Li, X. H., Wartho, J. A., Clark, C., Li, W. X., Zhang, C. L., \& Bao, C. M., 2010. Magmatic and metamorphic events during the early Paleozoic Wuyi-Yunkai Orogeny, southeastern South China: New age constraints and P-T conditions. Geological Society of America Bulletin 122, 772-793. doi.org/10.1130/B30021.1

Lin, S. F., Xing, G. F., Davis, D. W., Yin, C. Q., Wu, M. L., Li, L. M., Jiang, Y., \& Chen, Z. H., 2018. Appalachian-style multi-terrane Wilson cycle model for the assembly of South China. Geology 46, 319-322. doi.org/10.1130/G39806.1 
Lin, W., Faure, M., Monie, P., Schaerer, U., Zhang, L., \& Sun, Y., 2000. Tectonics of SE China: New insights from the Lushan massif (Jiangxi Province), Tectonics 19, 852-871. doi.org/10.1029/2000TC900009

Lin, W., Wang, Q. C., \& Chen, K., 2008. Phanerozoic tectonics of south China block: New insights from the polyphase deformation in the Yunkai massif. Tectonics 27, TC6004. doi.org/10.1029/2007TC002207

Liu, B. X., Liu, C. G., \& Qiu, Y. Q., 2001. The Pb-Pb isotopic ages of the Hezi gneissic granitic pluton in the southern Jiangxi and the geological significance. Volcanic geology and Ore Deposit 22(4), 264-268.

Liu, Q., Yu, J. H., Wang, Q., Su, B., Zhou, M. F., Xu, H., \& Cui, X., 2012. Ages and geochemistry of granites in the Pingtan-Dongshan Metamorphic Belt, Coastal South China: New constraints on Late Mesozoic magmatic evolution. Lithos 150, 268-286. doi.org/10.1016/j.lithos.2012.06.031

Lo, C. H., \& Yui, T. H., 1996. ${ }^{40} \mathrm{Ar} /{ }^{39} \mathrm{Ar}$ dating of high-pressıre, . n's in the Tananao basement complex, Taiwan. Journal of Geolological Society of Chi, a 35, (1), 13-30.

Manning, E. B., \& Elmore, R. D., 2015. An integrated 'aleomagnetic, rock magnetic, and geochemical study of the Marcellus shale in the ? lley and Ridge province in Pennsylvania and West Virginia. Journal of Geophysical Resu trch: Solid Eart, 120, 705-724. doi.org/10.1002/2014JB011418.

Mao, J. W, Li, H. Y., \& Wang, D. H., 1998. C "e torming of Mesozoic polymetallic deposits in South China and its relationship wit , M ntle Plume. Bulletin of Mineralogy, Petrology and Geochemistry 19(12), 130-132.

Mao, J. W., Cheng, Y. B., Chen, M. '., \& Pirajno, F., 2013. Major types and time-space distribution of Mesozoic ore de 10 'it. in South China and their geodynamic settings. Mineral Deposita 48, 267-294. doi.o g/ ^ 1007/s00126-012-0446-z

Mattauer, M., Matte Malaviei1.e, J., Tapponnier, P., Maluski, H., Xu, Z. Q., Lu, Z., \& Tang, Y., 1985. Tectonics of the Sinhı. Belt: build up and evolution of eastern Asia. Nature 317, 496-500. doi.org/10 10, er 17496a0

Mai Britt E. Mørk, Yår Kul erud, \& Stabel, A., 1988. Sm-nd dating of seve eclogites, norrbotten, sweden - evidenc. for early caledonian (505 ma) subduction. Contributions to Mineralogy \& Petrology, 99(3), 344-351.

Nagy, E. A., Maluski, H., Lepvrier, C., Schärer, U., Thi, P. T., Leyreloup, A., \& Van Thich, V., 2001. Geodynamic significance of the Kontum massif in central Vietnam: composite ${ }^{40} \mathrm{Ar} /{ }^{39} \mathrm{Ar}$ and U-Pb Ages from Paleozoic to Triassic. Journal of Geology 109, 755-770. doi.org/10.1086/323193

Nakano, N., Osanai, Y., Owada, M., Nam, T. N., Charusiri, P., \& Khamphavong, K., 2013. Tectonic evolution of high-grade metamorphic terranes in central Vietnam: constraints from large-scale monazite geochronology. Journal of Asian Earth Sciences 73, 520-539. doi.org/10.1016/j.jseaes.2013.05.010

Nex, P. A. M, Kinnaird, J. A., \& Oliver, G. J. H., 2001. Petrology, geochemistry and uranium mineralization of post-collisional magmatism around Goanikontes, southern Central Zone, Damara Orogen, Nambibia. Journal of African Earth Sciences 33, 481-502. 
doi.org/10.1016/S0899-5362(01)00096-3

Niu, J. W, Li, Z. X., \& Zhu, W. G., 2016. Palaeomagnetism and geochronology of mid-Neoproterozoic Yanbian dykes, South China: implications for a c. 820-800 Ma true polar wander event and the reconstruction of Rodinia. Geological Society, London, Special Publications 424(1), P424-11. doi.org/10.1144/SP424.11

Otsuki, K., 1992. Oblique subduction, collision of microcontinents and subduction of oceanic ridge: their implications on the Cretaceous tectonics of Japan. The Island Arc 1, 51-63. doi.org/10.1111/j.1440-1738.1992.tb00057.x

Qiu, Y. M., Gao, S., McNaughton, N. J., Groves, D. I., \& Ling, W., 2000. First evidence of $>3.2$ Ga continental crust in the Yangtze Craton of South China and its implications for Archean crustal evolution and Phanerozoic tectonics. Geology 28 (1), 11-14. doi.org/10.1130/0091-7613(2000)028<0011:feogcc >2.0.co;2

Raimondo, T., William, M. H., \& Collins J., 2014. Compres iv. 1 Intracontinental orogens: Ancient and modern perspectives. Earth Scionce Review 130, 128-153. doi.org/10.1016/j.earscirev.2013.11.009

Ren, J. S., 1964. Preliminary discussion on several problu.ns of Predevonian tectonics of the Southeastern China. Acta Geological Sinica 44'1), 418-430. (in Chinese with English abstract)

Ren, J. S., 1991. On the geotectonics of southerr C.ii a. Acta Geological Sinica 4(2), 111-130. doi.org/10.1111/j.1755-6724.1991.mp4002' v1.x

Ren, J. S., \& Chen, T. Y., 1989. Tectonic vol tion of the continental lithosphere in eastern China and adjacent areas. Journal of Sutheast Asian Earth Sciences 3, 17-27. doi.org/10.1016/0743-9547(89)900い-8

Ren, J. S., Chen, T. Y., \& Niu, B C., $: 990$. The tectonics and mineralization of continental lithosphere in the East Chin $₫$ a $_{\llcorner}{ }^{-1}$ adjacent region. Beijing: Science Press, 205p. (in Chinese with English abstract).

Ren, J. S., Niu, B. G., He, ㄱ s., Xie, G. L., \& Liu, Z. G., 1998. Tectonic framework and geodynamic evolution of eastern China. In: Ren, J.S., and Yang, W.R. (Eds.), The Lithospheric Text, re a ad Tectonic-Magmatic Evolution of the Eastern China. Beijing: Atomic Enegy Pubi shing House, 1-12 pp. (in Chinese with English abstract)

Ren, J. S., \& Li, C., LU16. Cathaysia oldlan and relevant problems: pre-Devonian tectonics of South China. Acta Geological Sinica 90(4), 607-614. doi.org/10.3969/j.issn.0001-5717.2016.04.001

Roger, F., Maluski, H., Leyreloup, A., Lepvrier, C., \& Tri Phan T., 2007. U-Pb dating of high temperature metamorphic episodes in the Kon Tum Massif (Vietnam). Journal of Asian Earth Sciences 30, 565-572. doi.org/10.1016/j.jseaes.2007.01.005

Roger, F., Maluski, H., Lepvrier, C., Vu Van, T., \& Paquette, J. L., 2012. LA-ICPMS zircons U/Pb dating of Permo-Triassic and Cretaceous magmatisms in Northern Vietnamgeodynamic implications. Journal of Asian Earth Sciences 48, 72-82. doi.org/10.1016/j.jseaes.2011.12.012

Rong, J. Y., 2018. Bio-evolution and environment. Hefei: Publishing House of the University of Science and Technology of China, 421p. (in Chinese with English abstract)

Rong, J. Y., Chen, X., Su, Y. Z., Ni, Y. N., Zhanm, R., Chen, T. G., Fu, L. P., Li, R. Y., \& Fan, J. X., 
2003. Silurian paleogeography of China. In Landing, E., \& Johnson, M. (Eds.), Paleography outside of Laurentia, New York: New York State Museum Bulletin, pp. 243-298.

Rong, J. Y., Zhan, R. B., Xu, H. G., Huang, B., \& Yu, G. H., 2010. Expansion of the Cathaysia Oldland through the Ordovician-Silurian transition: emerging evidence and possible dynamics. Science in Chin: Earth Sciences 53(1), 1-17. doi.org/10.1007/s11430-010-0005-3

Rong, J. Y., Wei, X., Zhan, R. B., \& Wang, Y., 2018. A deep water shelly fauna from the uppermost Ordovician in northwestern Hunan, South China and its paleoecological implications. Science in Chin: Earth Sciences 61, 730-744.

Rong, J. Y., Harper, D. A. T., Huang, B., Li, R. Y., Zhang, X. L., \& Chen, D., 2020. The latest Ordovician Hirnantian brachiopod faunas: New global insights. Earth-Science Reviews 208, 103280. doi.org/10.1016/j.earscirev.2020.103280

Sato, K., Yang, Z. Y., Yin, J. Y., Sun, Z. M., \& Otofuji, Y., 2001. Discrepant Cretaceous paleomagnetic poles between Eastern China and Indochina. A consequence of the extrusion of Indochina. Tectonophysics 334(2), 101-113. doi.org/10.101し',0040-1951(01)00061-0

Shen, W. Z., Lin, H. F., Shu, L. S., Zhang, F. R., \& Xiang, L., $200^{r}$.. ^ ^m- Id isotopic compositions of Cambrian-Ordovician strata at the Jinggangshan area in jiangxi Province: tectonic implications. Chinese Science Bulle $: n$ 54(10), 1750-1758. doi.org/10.1007/s11434-009-0214-3

Shimizu, H., \& Masuda, A., 1977. Cerium in chert as ^ 1 inc cation of marine environment of its formation. Nature 266, 346-348. doi.org/10.1038/2 j6s ‘ ‘a0

Shu, L. S., \& Charvet, J., 1996. Kinema Ic ind geochronology of the Proterozoic Dongxiang-Shexian ductile shear zone (iangnan region, South China). Tectonophysics 267(1-4), 291-302. doi.org/10.1016/,00< J-19j1(96)00104-7

Shu, L. S., \& Zhou, X. M., 2002. Late Mesoz :c tectonism of Southeast China. Geological Review 48(3), 249-260.

Shu, L.S., Charvet, J., Shi, Y.S., Fau re ${ }^{\star}$, Cluzel, D., \& Guo, L.Z., 1991, Structural analysis of the Nanchang-Wanzai sinistr al 'Icule shear zone (Jiangnan region, South China). Journal of Southeast Asian Earth Sci, nce. 6(1), 13-23

Shu, L. S., Zhou, G. Q., S. I. S., Yin, J., 1994. Study of the high-pressure metamorphic blueschist and its Latc Proterozoic age in the Eastern Jiangnan Orogenic Belt. Chinese Science Bulletin 3! 12 0-1204. doi.org/10.1007/BF01067541

Shu, L. S., Shi, Y. S., L 'o, L. Z., Charvet, J., \& Sun, Y., 1995. Plate Tectonic Evolution and the Kinematics of Cullisional Orogeny in the Middle Jiangnan, Eastern China. Nanjing: Publishing House of Nanjing University, 174p. (in Chinese with English abstract)

Shu, L.S., Sun, Y., Wang, D.Z., Faure, M., Charvet, J., \& Monie, P., 1998, Mesozoic doming extentional tectonics of Wugongshan, South China. Science in China (Series D) 41(6), 601-608

Shu, L. S., Deng, P., Wang, B., Yu, X. Q., Sun, Y., \& Tan, Z. Z., 2004. Lithological, Kinematic and Geochronological constraints on the Late Mesozoic Basin-Mountain Evolution in the Zhuguang-Nanxiong Area, South China. Science in China (Series D) 47(8), 673-688.

Shu, L.S., Faure, M., Jiang, S. Y., Yang, Q., \& Wang, Y. J., 2006. SHRIMP zircon U-Pb age, lithoand biostratigraphic analyses of the Huaiyu Domain in South China- Evidence for a Neoproterozoic orogen, not Late Paleozoic-Early Mesozoic collision. Episodes 29(4), 244-252. doi.org/10.1007/s00254-006-0521-9 
Shu, L. S., Deng P., Yu, J. H., Wang, Y. B., Jiang, S. Y., 2008a. The age and tectonic environment of the rhyolitic rocks on the western side of Wuyi Mountain, South China. Science China (Earth Science) 51(8), 1053-1063. doi.org/10.1007/s11430-008-0078-4

Shu, L. S., Faure, M., Wang, B., Zhou, X. M., \& Song, B., 2008b. Late Paleozoic-Early Mesozoic Geological Features of South China: Response to the Indosinian Collision Event in Southeast Asia. Comptes Rendus Geoscience 340, 151-165. doi.org/10.1016/j.crte.2007.10.010

Shu, L. S., Yu, J. H., Jia, D., Wang, B., Shen, W. Z., \& Zhang, Y. Q., 2008c. Early Paleozoic orogenic belt in the eastern segment of South China. Geological Bulletin of China 27(10), 1581-1593.

Shu, L. S., Zhou, X. M, Yu, J. H., Wang, B., Zhao, X. X., Jiang, S. Y., \& Deng, P., 2009. Mesozoic tectonic evolution of the southeast China block: New insights from basin analysis. Journal of Asian Earth Sciences 34, 376-391. doi.org/10.1016/j.jseaes.20 ${ }^{`} .06 .004$

Shu, L.S., Jahn, B.M., Yu, J.H., \& Faure, M., 2011. Geochronolog icaı and geochemical features of the Cathaysia block (South China): new evidence for the $N$ nıverozoic breakup of Rodinia. Precambrian Research 187, 263-276.

Shu, L. S., Jahn, B. M., Charvet, J., Santosh, M., Wang, د., Xu, X. S., \& Jiang, S. Y., 2014. Early Paleozoic depositional environment and Intraplau ctono-magmatism in the Cathaysia Block (South China): Evidence from thigraphic, structural, geochemical and geochronological investigations. Amer ${ }^{\circ}$ ca. Journal of Science 314, 154-186. doi.org/10.2475/01.2014.05

Shu, L. S., Wang, B., Cawood, P. A., Sanı'ı, M., \& Xu, Z. Q., 2015. Early Paleozoic and Early Mesozoic intraplate tectonic an' magmatic events in the Cathaysia Block, South China.

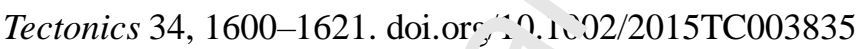

Shu, L. S., Song, M. J., \& Yao, J. I . 211 3. Forum Comments on: Appalachian-style multi-terrane Wilson cycle model $f_{0}$ the assembly of South China. Geology 46, e445, doi.org/10.1130/G40215 T.1.

Shu, L. S., Wang, J. Q., \& Var, J. L., 2019. Tectonic evolution of the eastern Jiangnan region, South China: rew findi igs and implications on the assembly of the Rodinia supercontinent. Precambrian Rese، "ch 322, 42-65. doi.org/10.1016/j.precamres.2018.12.007

Shu, L. S., Chen, X. 1., Lou, F. S., 2020. Pre-Jurassic Tectonics of the South China, Acta Geologica Sinica 94(2), 333-360. Doi: 10.19762/j.cnki.dizhixuebao.2020046.

Shui, T., 1988. Tectonic framework of the. continental basement of southeastern China. Scientia Sinica (Series B) 31, 24-34.

Song, M. J., Shu, L. S., Santosh, M., \& Li, J. Y., 2015. Late Early Paleozoic and Early Mesozoic intracontinental orogeny in the South China Craton: geochronological and geochemical evidence. Lithos 232, 360-374. doi.org/10.1016/j.lithos.2015.06.019

Song, M. J., Shu, L. S., \& Santosh, M., 2017. Early Mesozoic intracontinental orogeny and stress transmission in South China: evidence from Triassic peraluminous granites. Journal of the Geological Society, London 174, 591-607. doi.org/10.1144/jgs2016-098

Stampfli, G. M., Borel, G. D., 2002. A plate tectonic model for the Paleozoic and Mesozoic constrained by dynamic plate boundaries and restored synthetic oceanic isochrones. Earth and Planetary Science Letters 196, 17-33. 
Stille, H. (1924). Grundfragen der Vergleichenden: Tektonik (pp. 1-433). Berlin: Borntraeger.

Sun, J. J., Shu, L. S., Santosh, M., \& Wang, L. S., 2017. Neoproterozoic tectonic evolution of the Jiuling terrane in the central Jiangnan orogenic belt (South China): Constraints from magmatic suites. Precambrian Research 302, 279-297. doi.org/10.1016/j.precamres.2017.10.003

Sun, J. J., Shu, L. S., Santosh, M., \& Wang, L. S., 2018. Precambrian crustal evolution of the central Jiangnan orogenic belt (South China): Evidence from detrital zircon U-Pb ages and $\mathrm{Hf}$ isotopic compositions of Neoproterozoic metasedimentary rocks. Precambrian Research 318, 1-24. doi.org/10.1016/j.precamres.2018.09.008

Sun, Z. M., Wang, X. L., Qi, L., Zhang, F. F., Wang, D., Li, J. Y., Yu, M. G., \& Shu, X. J., 2018. Formation of the Neoproterozoic ophiolites in southern China: new constraints from trace element and PGE geochemistry and Os isotopes. Precamı ian Research 309, 88-101. doi.org/10.1016/j.precamres.2017.12.042

Tran, H. T., Zaw, K., Halpin, J. A., Manaka, T., Meffre, S., Lai, C _ Zee, Y. J., \& Le, H. V., 2014. The Tam Ky-Phuoc Son shear zone in Central $V_{1}$ tnar 1 : tectonic and metallogenic implications. Gondwana Research 26(1), 144-164. doi.c-o/10.1016/j.gr.2013.04.008

Uyeda, S., 1983. Comparative subd tolo ;y. Episodes 2, 19-24. doi.org/10.18814/epiiugs/1983/v6i2/005

Wan, Y. S., Liu, D. Y., Xu, M. H., Zhuang, J. M., ؟ or s, 3., Shi, Y. R., \& Du, L. L., 2007. SHRIMP $\mathrm{U}-\mathrm{Pb}$ zircon geochronology and geochemi $\mathrm{ry}$ or metavolcanic and metasedimentary rocks in Northwestern Fujian, Cathaysia Blor k, C.ina: tectonic implications and the need to redefine lithostratigraphic units. Gondwana Reseu. ch 12, 166-183. doi.org/10.1016/j.gr.2006.10.016

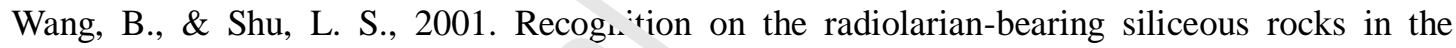
Jiangxi-Zhejiang-Anhui region, Sr ul . China. Geological Reviw 47(4), 337-344.

Wang, B., Shu, L. S., Faure, N.., : ’hn, B. M., Lo, C. H,, Charvet, J., \& Liu, H. S., 2014. Phanerozoic multistage te ton - rejuvenation of the continental crust of the Cathaysia block: insights from structura investigations and combined zircon U-Pb and mica ${ }^{40} \mathrm{Ar} /{ }^{39} \mathrm{Ar}$ geochronology of the $\mathrm{g}_{2} \cdot r$ toids in southern Jiangxi province. The Journal of Geology 122, 309-328. doi.c" ${ }^{*} / 1$ ? $7.10: 6 / 675664$

Wang, D., Wang, X. L. Zhou, J. C., \& Shu, X.J., 2013. Unraveling the Precambrian crustal evolution by Neoproterozoic conglomerates, Jiangnan orogen: $\mathrm{U}-\mathrm{Pb}$ and $\mathrm{Hf}$ isotopes of detrital zircons. Precambrian Research 233, 223-236. doi.org/10.1016/j.precamres.2013.05.005

Wang, D. Z., Shu, L. S., Faure M., \& Sheng, W. Z., 2001. Mesozoic magmatism and granitic dome in the Wugongshan massif, Jiangxi Province and their genetical relationship to the tectonic events in Southeast China. Tectonophysics 339, 259-277. doi.org/10.1016/S0040-1951(01)00130-5

Wang, D. Z., \& Zhou, X. M., 2002. Genesis of Late Mesozoic volcanic-intrusive complex of Southeast China and crustal evolution. Beijing: Science Press, 295p.

Wang, D. Z., \& Shu, L. S., 2012. Late Mesozoic basin-and-range tectonics and related igneous rock assemblages of Southeast China. Geoscience Frontiers 3(2), 109-124. doi.org/10.1016/j.gsf.2011.11.007 
Wang, J., \& Li, Z. X., 2003. History of Neoproterozoic rift basins in South China: implications for Rodinia break-up. Precambrian Research 122(1-4), 141-158. doi.org/10.1016/S0301-9268(02)00209-7

Wang, J. Q., Shu, L. S., \& Yu, J. H., 2017. From the Neoproterozoic mafic rock to the Silurian high-grade metamorphic rock: evidence from zircon U-Pb geochronological, bulk-rock geochemical and mineral EPMA studies of Longyou garnet amphibolite in SE China. Journal of Asian Earth Sciences 141, 7-23. doi.org/10.1016/j.jseaes.2016.11.030

Wang, L. J., Griffin, W. L., Yu, J. H., \& O'Reilly, S. Y., 2010. Precambrian crustal evolution of the Yangtze block tracked by detrital zircons from Neoproterozoic sedimentary rocks. Precambrian Research 177 (1), 131-144. doi.org/10.1016/j.precamres.2009.11.008

Wang, W., Zhou, M. F., Zhao, J. H., Pandit, M. K., Zheng, J. P., \& Liu, Z. R., 2016. Neoproterozoic active continental margin in the southeastern ngtze block of South China: evidence from the ca. 830-810 Ma sedimentary strata. Sedi we. ary Geology 342, 254-267. doi.org/10.1016/j.sedgeo.2016.07.006

Wang, X. L., Zhou, J. C., Qiu, J. S., Zhang, W. L., Liu, X. M., \& Z lang, G. L., 2006. LA-ICP-MS $\mathrm{U}-\mathrm{Pb}$ zircon geochronology of the Neoproterozoic ig. ${ }^{\circ}$ ous rocks from Northern Guangxi Province, South China: implications for the tecto: c ev slution. Precambrian Research 145, 111-130. doi.org/10.1016/j.precamres.2005.11.014

Wang, X. L., Zhou, J. C., Griffin, W. L., Wang, R. C, Ciu, J. S., O’Reilly, S. Y., Xu, X. S., \& Liu, X. M., 2007. Detrital zircon geochronoi oy of Precambrian basement sequences in the Jiangnan orogen: dating the assemr y c the Yangtze and Cathaysia Blocks. Precambrian Research 159, 117-131. doi.org/10.1010; nrecamres.2007.06.005

Wang, X. L., Shu, L. S., Xing, G. F., Zhu · J. C., Tang, M., Shu, X. J., Qi, L., \& Hu, Y. H., 2012. Post-orogenic extension in the ar ie.. part of the Jiangnan Orogenic belt: evidence from ca 800-760 Ma volcanic , $\mathrm{cks}$. Precambrian Research 222-223, 404-423. doi.org/10.1016/j.precamr s.2 $\iota^{1} 1.07 .003$

Wang, X. L., Zhou, J. C., Grı" n, v. L., Zhao, G. C., Yu, J. H., Qiu, J. S., Zhang, Y. J., \& Xing, G. F., 2014. Geochemical $\cdots$ ation across a Neoproterozoic orogenic belt: Isotopic evidence from granitoid ai $\mathrm{d} \mathrm{m}$ tasedimentary rocks of the Jiangnan orogen, China. Precambrian Research 242, 154- '71. doi.org/10.1016/j.precamres.2013.12.023

Wang, Y., Rong, J. Y., Iang, P., Huang, B., Zhang, X. L., Xu, H. H., Liu, F., Jiang, Q., \& Wang, Y., 2020. Features of Middle Paleozoic stratigraphic interface in South China and geotectonic significances. Science in China: Earth Sciences 63. doi.org/10.1360/SSTe-2020-0079

Wang, Y. J., Fan, W. M., Guo, F., Peng, T. P., \& Li, C. W., 2003. Geochemistry of Mesozoic mafic rocks adjacent to the Chenzhou-Linwu fault, South China: implications for the lithospheric boundary between the Yangtze and Cathaysia blocks. International Geology Review 45, 263-286. doi.org/10.2747/0020-6814.45.3.263

Wang, Y.J., Fan, W.M., Sun, M., Liang, X.Q., Zhang, Y.H., \& Peng, T.P., 2007. Geochronological, geochemical and geothermal constraints on petrogenesis of the Indiosinian peraluminous granites in the South China Block: a case study in the Hunan Province. Lithos 96, 475-502. doi.org/10.1016/j.lithos.2006.11.010

Wang, Y. J., Zhang, F. F., Fan, W. M., Zhang, G. W., Chen, S. Y., Cawood, P.A., \& Zhang, A. M., 
2010. Tectonic setting of the South China block in the Early Paleozoic: Resolving intracontinental and ocean closure models from detrital zircon U-Pb geochronology. Tectonics 29, TC6020. doi.org/10.1029/2010TC002750

Wang, Y. J., Zhang, A. M., Fan, W. M., Zhao, G. C., Zhang, G. W., Zhang, Y. Z., Zhang, F. F., \& Li, S. Z., 2011. Kwangsian crustal anatexis within the eastern South China Block: Geochemical, zircon U-Pb geochronological and $\mathrm{Hf}$ isotopic fingerprints from the gneissoid granites of Wugong and Wuyi-Yunkai domains. Lithos 127, 239-260. doi.org/10.1029/2010TC002750

Wang, Y. J., Zhang, Y. Z., Fan, W. M., Yang, J., \& Zhang, A. M., 2012a. Earliest Neoproterozoic (ca. $1.0 \mathrm{Ga}$ ) arc-back-arc basin nature along the northern Yunkai Domain of the Cathaysia Block: Geochronological and geochemical evidence from the metabasite. Precambrian Research 220-221, 217-233. doi.org/10.1016/j.precamres.2012.08.003

Wang, Y. J., Wu, C. M., Zhang, A. M., Fan, W. M., Zhang, Y. H., Zı. ng, Y. Z., Peng, T. P., \& Yin, C. Q., 2012b Kwangsian and Indosinian reworking of th _ - astern South China Block: constraints on zircon $\mathrm{U}-\mathrm{Pb}$ geochronology and metamorphis $\mathrm{r}_{1} \wedge f$ amphibolites and granulites. Lithos 150, 227-242. doi.org/10.1016/j.lithos.2012.04.02.'

Wang, Y. J., Fan, W. M., Zhang, G. W., \& Zhang, Y. Z., 201_' Phanerozoic tectonics of the South China Block: key observations and controversi: G indwana Research 23, 1273-1305. doi.org/10.1016/j.gr.2012.02.019

Wang, Y. J., Zhang, Y. Z., Fan, W. M., Geng, - I Y, Zou, H. P., \& Bi, X. W., 2014. Early Neoproterozoic accretionary assemblaqe i. the Cathaysia block: geochronological, Lu-Hf isotopic and geochemical evidence fro 1 granitoid gneisses. Precambrian Research 249, 144-161. http://dx.doi.org/10.1016/j.prec. mres.2014.05.003

Wang, Y. J., He, H. Y., Gan C. S., \& 7hang Y. Z., 2018. Petrogenesis of the early Silurian Dashuang high-Mg basalt-al de s1.-dacite in eastern South China: origin from a palaeosubduction- modified na. +le. Journal of the Geological Society, London 175, 949-966. doi.org/10.1144/jgs2018-1 )2

Wang, Y. J., Zhang Y. Z., Ca.'nou, P. A., Zhou, Y. Z., Zhang, F. F., Yang, X., \& Cui, X., 2019. Early Neoproterozoir as ably and subsequent rifting in South China: Revealed from mafic and ultramafi- $\mathrm{r}$ cks. central Jiangnan Orogen. Precambrian Research 331, https: //doi.org/10.1016/J.1 recamres.2019.105367

Wang, Y. J., Wang, Y. K., Qian, X., Zhang, Y. Z., Gan, C. S., Senebouttalath, V., \& Wang, Y., 2020a. Early Paleozoic subduction in the Indochina interior: Revealed by Ordo-Silurian mafic-intermediate igneous rocks in South Laos. Lithos 362-363, 105488. doi.org/10.1016/j.lithos.2020.105488

Wang, Y. J., Zhang, Y. Z., Qian, X., Senebouttalath, V., Wang, Y., Wang, Y. K., \& Gan, C. S., 2020b. Ordo-Silurian assemblage in the Indochina interior: geochronological, elemental and $\mathrm{Sr}-\mathrm{Nd}-\mathrm{Pb}-\mathrm{Hf}-\mathrm{O}$ isotopic constraints of early Paleozoic granitoids in South Laos. Geological Society of America Bulletin. doi.org/10.1130/B35605.1

Wang, Z. H., \& Lu, H. F., 1997. Study of ${ }^{40} \mathrm{Ar} /{ }^{39}$ Ar geochronology on the Changle-Nan'ao ductile shear zone. Science in China (Series D) 27(4), 294-299.

Mckerrow, W. S., Mac Niocaill, C., \& Dewey, J. F., 2000. The caledonian orogeny redefined. Journal of the Geological Society, 157(6), 1149-1154. 
Wei, W., Chen, Y., Faure, M., Martelet, G., Lin, W., Wang, Q., Yan, Q., \& Hou, Q., 2016. An early extensional event of the South China Block during the Late Mesozoic recorded by the emplacement of the Late Jurassic syntectonic Hengshan Composite Granitic Massif (Hunan, SE China). Tectonophysics 672-673, 50-67._doi.org/10.1016/j.tecto.2016.01.028

Williams, H., 1995. Geology of the appalachian-caledonian orogen in canada and greenland. Gsw Books.

Wu, F.Y., Sun, D.Y., Ge, W.C., Zhang, Y.B., Grant, M.L., Wilde, S.A., Jahn, B.M., 2011. Geochronology of the Phanerozoic granitoids in northeastern China. J. Asian Earth Sci. 41, $1-30$.

Wu, Y. B., Gao, S., Gong, H. J., Xiang, H., Jiao, W. F., \& Yang, S. H., 2009. Zircon U-Pb age, trace element and $\mathrm{Hf}$ isotope composition of Kongling terrane in the Yangtze craton: refining the timing of Paleoproterozoic high-grade metamorphism. Journal of Metamorphical Geology 27, 461-477._doi.org/10.1111/j.1525-1314.2009.008'u..

Wu, Y. B., Zheng, Y. F., 2013. Tectonic evolution of a composite c ${ }^{11 i}$, lon orogen: an overview on the Qinling-Tongbai-Hong'an-Dabie-Sulu orogenic i alt n central China. Gondwana Research, 23(4), 1402-1428.

Xiang, L., \& Shu, L. S., 2010. Predevonian tectonic e vluti n of the eastern South China block: geochronological evidence from detrital zircons. Scı.nce in China: Earth Sciences 53, 1427-1444. doi.org/10.1007/s11430-010-406 - -

Xiao, W. J., \& He, H. Q., 2005. Early Mesozoi thrust tectonics of the northwest Zhejiang region (Southeast China). Geological s, ciety of America Bulletin 117, 1-17. doi.org/10.1130/B25417.1

Xie, G. Q., Hu, R. Z., Zhao, J. H., \& Jian it and Mesozoic large-scaled $\mathrm{m}$ (ta' 10 , Geotectonica et Metallogeni $\iota$ ८_(2), 179-186.

Xing, G. F., Wang, X. L., Wan Y. S. Chen, Z. H., Jiang, Y., Kitajima, K., Ushikubo, T., \& Gopon, P., 2014. Diversity in e. ${ }^{-1} \mathrm{~V}$ urustal evolution: 4100 Ma zircons in the Cathaysia Block of southern China. Sciently: report. doi.10.1038/srep05143

Xin, Y. J., Li, J. H., Do. o, S W., Zhang, Y. Q., Wang, W. B., \& Sun, H. S., 2017. Neoproterozoic post-collisional exı nsion of the central Jiangnan Orogen: Geochemical, geochronological, and Lu-Hf isotopic constraints from the ca. 820-800 Ma magmatic rocks. Precambrian Research 294, 91-110. doi.org/10.1016/j.precamres.2017.03.018

Xu, B., \& Qiao, G. S., 1989. The Sm-Nd isotopic age of Late Proterozoic ophiolite of Northeastern Jiangxi and its tectonic environment. Journal of Nanjing University (Earth Sciences) 1(3), $108-114$.

Xu, B., Guo, L. Z., \& Shi, Y. S., 1992. Proterozoic terranes and multiphase collision orogensin Anhui-Zhejiang-Jiangxi area. Beijing: Geological Publishing House, 112p. (in Chinese with English abstract)

Xu, X. B., Zhang, Y. Q., Shu, L. S., \& Jia, D., 2011. La-ICP-MS U-Pb and ${ }^{40} \mathrm{Ar} /{ }^{39} \mathrm{Ar}$ geochronology of the sheared metamorphic rocks in the Wuyishan: Constraints on the timing of Early Paleozoic and Early Mesozoic tectono-thermal events in SE China. Tectonophysics 501, 71-86. doi.org/10.1016/j.tecto.2011.01.014 
Xu, X. B., Lin, S. F., Tang, S., \& Zhang, X. F., 2018. Transformation from Neoproterozoic sinistral to Early Paleozoic dextral shearing for the Jingdezhen ductile shear zone in the Jiangnan Orogen, South China. Journal of Earth Science 29(2), 376-390.

Xu, X. S., O'Reilly, S. Y., Griffin, W. L., Deng, P., \& Pearson, N. J., 2005. Relict Proterozoic basement in the Nanling mountains (SE China) and its tectonothermal overprinting. Tectonics 24, 1-16. http://dx.doi.org/10.1029/2004TC001652

Xu, X. S., O'Reilly, S. Y., Griffin, W. L., Wang, X. L., Pearson, N. J., \& He, Z. Y., 2007. The crust of Cathaysia: Age, assembly and reworking of two terranes. Precambrian Research 158(1-2), 51-78. http://dx.doi.org/10.1016/j.precamres.2007.04.010

Xu, Y. G., Chuang, S. L., \& Jahn, B. M., 2001. Petrologic and geochemical constrains on the petrogenesis of Permian-Triassic Emeishan flood basalts in southwestern China. Lithos 58, 145-168. http://dx.doi.org/10.1016/s0024-4937(01)00055-x

Xu, Y. J., Cawood, P. A., Du, Y. S., Zhong, Z. Q., \& Hughes, N c. 2v14. Terminal suturing of

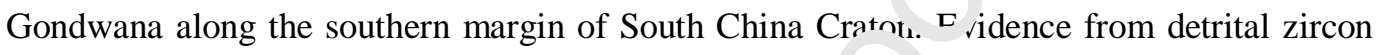
$\mathrm{U}-\mathrm{Pb}$ ages and $\mathrm{Hf}$ isotopes in Cambrian and Ordovician strat ^, Hainan Island. Tectonics 33, 2490-2504._http://dx.doi.org/10.1002/2014TC003748

Xu, Y.J., Cawood, P., Du, Y.S., 2016. Intraplate oroge: esis n response to Gondwana assembly: Kwangsian Orogeny, South China. Am. J. Sci. 316 32y 362.

Xu, Z. Q., Yang, J. S., Ji, S. C., Zhang, Z. M., L, I. 3., Liu, F. L., Zhang, J. X., \& Wu, C. L., 2010. On the continental tectonics and d, amics of China. Acta Geological Sinica 84(1), $1-29$.

Xu, Z. Q., \& Zhang, G. W., 2013. Tectonics a. ${ }^{-1}$ dynamics of China (East Asia). Science in China: Earth Sciences 43(10), 1527-1538. _tp://dx.doi.org/10.1360/zd-2013-43-10-1527

Yan, C. L., Shu, L. S., Faure, M., Cl.eı, Y., \& Li, C., 2017. Early Paleozoic intracontinental orogeny in the Yunkai Don alı, South China Block: new insights from field observations, zircon U-Pb geochronolr gicai and geochemical investigations. Lithos 268-271, 320-333. http://dx.doi.org/10.1010," i litos.2016.11.013

Yan, C. L., Shu, L. S., Farre, M , Chen, Y., Huang, R. B., 2019. Time constraints on the closure of the Paleo-South C. ina ' )cean and the Neoproterozoic assembly of the Yangtze and Cathaysia blocks: insight fru n new detrital zircon analyses. Gondwana Research 73, 175-189. doi.org/10.1016/j.gr.2019.03.018

Yan, C. L., Shu, L. S., Chen, Y., Faure, M., Feng, Z. H., Zhai, M. G., 2021. The construction mechanism of the Neoproterozoic S-type Sanfang-Yuanbaoshan granitic plutons in the Jiangnan Orogenic Belt, South China: Insights from geological observation, geochronology, AMS and Bouguer gravity modeling. Precambrian Research 354, doi.org/10.1016/j.precamres.2020.106054

Yan, D. P., Li, Y. Q., Kennedy, A. K., Zhou, M. F., \& Ding, J., 2002. SHRIMP U-Pb zircon geochronological and geochemical evidence for Neoproterozoic arc-magmatism along the western margin of the Yangtze block, South China. Earth and Planetary Science Letters 196, 51-67. doi.org/10.1016/S0012-821X(01)00595-7

Yang, Q., Wang, Y. J., Yin, L. M., Shu, L. S., Lou, F. S., \& Wang, B., 2005. On the age of the ophiolitic complexes in northeastern Jiangxi: a micropaleontological analysis. Acta 
Geologica Sinica 79, 801-805. doi.org/10.1111/j.1755-6724.2005.tb00894.x

Yang, Z. Y., \& Besse, J., 1993. Paleomagnetic study on Permian and Mesozoic sedimentary rocks from North Thailand supports the extrusion model for Indochina. Earth and Planetary Science Letters 117, 525-552. doi.org/10.1016/0012-821X(93)90101-E

Yang, Z. Y., Yin, J. Y., Sun, Z. M., Otofuji, Y., \& Sato, K., 2001. Disrepancy Cretaceous paleomagnetic poles between eastern China and Indochina: A consequence of the extrusion of Indochina. Tectonophysoics 334, 101-113. doi.org/10.1016/S0040-1951(01)00061-0

Yang, Z. Y., Sun, Z. M., Yang, T. S., \& Pei, J. L., 2004. A long connection (750-380 Ma) between South China and Australia: paleomagnetic constraints. Earth and Planetary Science Letter, 220(3-4), 423-434. doi.org/10.1016/S0012-821X(04)00053-6

Yao, J. L., Shu, L. S., \& Santosh, M., 2011. Detrital zircon U-Pb geochronology, Hf-isotopes and geochemistry-new clues for the Precambrian crustal evolutic of Cathaysia block, South China. Gondwana Research 20, 553-567. doi.org/10.1016/j.ร...`11.01.005

Yao, J. L., Shu, L. S., Santosh, M., \& Li, J. Y., 2013. Geochrnnciny and Hf isotope of detrital zircons from Precambrian sequences in the eastern $J$ ang an Orogen: Constraining the assembly of Yangtze and Cathaysia Blocks in South Cri 'a. Journal of Asian Earth Sciences, 74, 225-243. doi.org/10.1016/j.jseaes.2012.08.01C

Yao, J. L., Shu, L. S., Santosh, M., \& Zhao, C. C., 2014a. Neoproterozoic arc-related mafic-ultramafic rocks and syn-collision gra it $\_$om the western segment of the Jiangnan Orogen, South China: constraints on the Neoproterozoic assembly of the Yangtze and Cathaysia Blocks. Pr car brian Research 243, 39-62. doi.org/10.1016/j.precamres.2013.12.02,

Yao, J. L., Shu, L. S., Santosh, M., a Zu, Z. Q., 2014b. Palaeozoic metamorphism of the Neoproterozoic basement in $\mathrm{N}$ : 'a aysia: Zircon U-Pb ages, Hf isotope and whole rock geochemistry from the Chrnca: uroup. Journal of the Geological Society, London 171, 281-297. doi.org/10.1144, gs' $213-036$

Yao, J. L., Shu, L. S., Santos' MI., \& Li, J. Y., 2015. Neoproterozoic arc-related andesite and orogeny-related uncnn ${ }^{-r}$.ity in the eastern Jiangnan orogenic belt: constraints on the assembly of th - Y. ngtz: and Cathaysia blocks in South China. Precambrian Research 262, 84-100. doi.org/1U. '016/j.precamres.2015.02.021

Yao, J. L., Cawood, Y. A., Shu, L. S., Santosh, M., \& Li, J. Y., 2016. An early Neoproterozoic accretionary prism ophiolitic mélange from the western Jiangnan orogenic belt, South China. The Journal of Geology 124, 587-601. doi.org/10.1086/687396

Yao, J. L., Shu, L. S., Cawood, P. A., \& Li, J. Y., 2017. Constraining timing and tectonic implications of Neoproterozoic metamorphic event in the Cathaysia Block, South China. Precambrian Research 293, 1-12. doi.org/10.1016/j.precamres.2017.01.032

Yao, J. L., Cawood, P. A., Shu, L. S., \& Zhao, G. C., 2019. The Jiangnan Belt in South China: a 970-820 Ma Rodinia margin accretionary orogen. Earth-Science Review, 196, https: //doi.org/10.1016/j.earscirev.2019.05.016

Ye, M. F., Li, X. H., Li, W. X., Liu, Y., \& Li, Z. X., 2007. SHRIMP zircon U-Pb geochronological and whole-rock geochemical evidence for an early Neoproterozoic Sibaoan magmatic arc along the southeastern margin of the Yangtze block. Gondwana Research 12, 144-156. 
doi.org/10.1016/j.gr.2006.09.001

Yu, J. H., Chen, M. J., Fang, Y. T., Huang, Z. C., Bian, L. Z., 1988. The Sinian and Early Paleozoic stratigraghic features and stratigraphic terrans in the continental margin of Eastern China. Journal of Nanjing University (Natural Sciences) 24(1), 1-8.

Yu, J. H., O’Reilly, S. Y., Wang, L. J., Griffin, W. L., Zhang, M., Wang, R. C., Jiang, S. Y., \& Shu, L. S., 2008. Where was South China in the Rodinia supercontinent? Evidence from U-Pb ages and Hf isotopes of detrital zircons. Precambrian Research 164 (1-2), 1-15. doi.org/10.1016/j.precamres.2008.03.002

Yu, J. H., Wang, L. J., O’Reilly, S. Y., Griffin, W. L., Zhang, M., Li, C. Z., \& Shu, L.S., 2009. A Paleoproterozoic orogeny recorded in a long-lived cratonic remnant (Wuyishan terrane), eastern Cathaysia Block, China. Precambrian Research 174, 347-363. doi.org/10.1016/j.precamres.2009.08.009

Yu, J. H., O’Reilly, S. Y., Wang, L. J., Griffin, W. L., Zhou, M. F. «ı`ng, M., \& Shu, L. S., 2010. Components and episodic growth of Precambrian crust in the ${ }^{-}$.naysia Block, South China: Evidence from $\mathrm{U}-\mathrm{Pb}$ ages and $\mathrm{Hf}$ isotopes of zirc $\mathrm{ns} \mathrm{n}$ Neoproterozoic sediments. Precambrian Research 181, 97-114. doi.org/10.1016/i.p.`camres.2010.05.016

Zeng, W., Zhou, H. W., Zhong, Z. Q., Zeng, S. G., \& 'i, H . M., 2005. The single-grain zircon $\mathrm{U}-\mathrm{Pb}$ age from Neoproterozoic magmatic rocks in the s utheastern Guizhou and the tectonic significance. Geochemistry 34(6), 548-556.

Zhang, A. M., Wang, Y. J., Fan, W. M., Zhano, Z Z., \& Yang, J., 2012. Earliest Neoproterozoic (ca. $1.0 \mathrm{Ga}$ ) arc-back-arc basin nature al ng + te northern Yunkai Domain of the Cathaysia Block: Geochronological and geochemical evinnce from the metabasite. Precambrian Research 220-221, 217-233.

Zhang, B., Guo, F., Zhang, X., Wu, '.. W.ng, G., \& Zhao, L., 2019. Early Cretaceous subduction of Paleo-Pacific Ocean in ne rastal region of SE China: Petrological and geochemical constraints from the mafir intr $n$-ions. Lithos 334, 8-24.

Zhang, G. W., Guo, A. L., W'ng, Y. J., Li, S. Z., Dong, Y. P., Liu, S. F., \& He, D. F., 2013. Tectonics of South $\mathrm{Ch}_{\mathrm{n}} \backsim$ Continent and its implications. Science China: Earth Science, 56(11), 1804-1 92 doi org/10.1007/s11430-013-4679-1

Zhang, S. B., Zheng, Y. F., Wu, Y. B., Zhao, Z. F., Gao, S., \& Wu, F. Y., 2006. Zircon U-Pb age and $\mathrm{Hf}$ isotope eviuence for $3.8 \mathrm{Ga}$ crustal remnant and episodic reworking of Archean crust in South China. Earth and Planetary Science Letters 252, 56-71. doi.org/10.1016/j.eps1.2006.09.027

Zhang, S. B., Wu, R. X., \& Zheng, Y. F., 2012. Neoproterozoic continental accretion in South China: Geochemical evidence from the Fuchuan ophiolite in the Jiangnan orogen. Precambrian Research 220-221, 45-64. doi.org/10.1016/j.precamres.2012.07.010

Zhang, X. S., Xu, X. S., Xia, Y., \& Liu, L., 2017. Early Paleozoic intracontinental orogeny and post-orogenic extension in the South China Block: Insights from volcanic rocks. Journal of Asian Earth Sciences 141, 24-42. doi.org/10.1016/j.jseaes.2016.07.016

Zhang, Y., Jia, D., Muxworthy, A. R., Li, Y. X., Xia, B., Xie, Z. Y., Hu, J., \& Zi, J. P., 2018. The Chemical Remagnetization of Ediacaran Dolomite in the Taishan Paleo-Reservoir, South China. Journal of Geophysical Research: Solid Earth 123, 6161-6175. 
doi.org/10.1029/2018JB015547

Zhang, Y., Shu, L. S., \& Chen, X. Y., 2011. Study of geochemistry, geochronology and petro-genesis of the Early Paleozoic granitic plutons in the central-southern Jiangxi Province. Science in China: Earth Sciences 54(10), 1492-1510. doi.org/

Zhang, Y., Yang, J. H., Sun, J. F., Zhang, J. H., Chen, J. Y., \& Li, X. H., 2015. Petrogenesis of Jurassic fractionated I-type granites in Southeast China: Constraints from whole-rock geochemical and zircon U-Pb and Hf-O isotopes. Journal of Asian Earth Sciences 111, 268-283. doi.org/10.1016/j.jseaes.2015.07.009

Zhang, Y. Z, Wang, Y. J, Fan, W. M, Zhang, A. M, \& Ma, L.Y., 2012. Geochronological and geochemical constraints on the metasomatised source for the Neoproterozoic (825 Ma) high-mg volcanic rocks from the Cangshuipu area (Hunan Province) along the Jiangnan domain and their tectonic implications. Precambrian N earch 220-221, 139-157. doi.org/10.1016/j.precamres.2012.07.003

Zhang, Y. Z., Wang, Y. J., Zhang, Y. H., \& Zhang, A. M., 2015 rar proterozoic assembly of the Yangtze and Cathaysia blocks: Evidence from the Cang huil u Group and associated rocks along the Central Jiangnan Orogen, South China. Trecambrian Research 269, 18-30. http://dx.doi.org/10.1016/j.precamres.2015.08.003

Zhang, Y. Z., \& Wang, Y. J., 2016. Early Ner prote :zoic (840 Ma) arc magmatism: Geochronological and geochemical constrai ts 0 . the metabasites in the Central Jiangnan $\begin{array}{llll}\text { Orogen. Precambrian } & \text { Kesearch }\end{array}$ http://dx.doi.org/10.1016/j.precamrer 201 j.11.006

Zhao, C. H., Hong, Q. L., He, K. Z., Mo, X. Y., Tai, D. Q., Ye, D. L., Ye, Z., \& Lin, P.Y., 1995. The discovery of the Late Paleozoic -adiolarian chert in the ophiolitic mélange along the NW Jiangxi fault and its implication Ch.ese Science Bulleti, 40, 2161-2163.

Zhao, G. C., \& Cawood, P. A., 1',yy. Tectonothermal evolution of the Mayuan assemblage in the Cathaysia Block: new evi len - for Neoproterozoic collional-related assembly of the South China craton. American , vur.al of Science 299, 309-339. doi.org/10.2475/ajs.299.4.309

Zhao, G. C., \& Cawood t. A., 2012. Precambrian geology of China. Precambrian Research 222-223, 13-5' de i.ors 10.1016/j.precamres.2012.09.017

Zhao, G. C., 2015. Jiaı 'nan orogenic belt in South China: developing from divergent double subduction. Gonawana Research, 27, 1173-1180. doi.org/10.1016/j.gr.2014.09.004

Zhao, G. C., Wang, Y. J., Huang, B. C., Dong, Y. P., Li, S. Z., Zhang, G. W., \& Yu, S., 2018. Geological reconstructions of the East Asian blocks: From the breakup of Rodinia to the assembly of Pangea. Earth-Science Reviews 186, 262-286. doi.org/10.1016/j.earscirev.2018.10.003

Zhao, J. H., Zhou, M. F., \& Zhen, J. P., 2013. Constraints from zircon U-Pb ages, O and Hf isotopic compositions on the origin of Neoproterozoic peraluminous granitoids from the Jiangnan Fold Belt, South China. Contribution to Mineral Petrology 166, 1505-1519. doi.org/10.1007/s00410-013-0940-z

Zhao, J. H., Li, Q. W., Liu, H., Wang, W., 2018b. Neoproterozoic magmatism in the western and northern margins of the Yangtze Block (South China) controlled by slab subduction and subduction-transform-edge-propagator. Earth-Science Reviews 187, 1-18. 
doi.org/10.1016/j.earscirev.2018.10.004

Zheng, Y. F., Fu, B., Gong, B., \& Li, L., 2003. Stable isotope geochemistry of ultrahigh pressure metamorphic rocks from the Dabie-Sulu orogen in China: implications for geodynamics and fluid regime. Earth-Science Reviews, 62(1-2), 105-161.

Zheng, Y. F., Zhao, Z. F., \& Zhang, S. B., 2007. Contrasting zircon Hf and O isotopes in the two episodes of Neoproterozoic granitoids in South China: Implications for growth and reworking of continental crus. Lithos 96, 127-150. doi.org/10.1016/j.lithos.2006.10.003Zhong, Y. F., Ma, C. Q., Zhang, C., Wang, S. M., She, Z. B., Liu, L., \& Xu, H. J.. 2013. Zircon U-Pb age, Hf isotopic compositions and geochemistry of the Silurian Fengdingshan I-type granite Pluton and Taoyuan mafic-felsic Complex at the southeastern margin of the Yangtze Block. Journal of Asian Earth Sciences 74, 11-24. doi.org/10.1016/j.jseaes.2013.05.025

Zhou, G. Q., \& Zou, H. B., 1996. Precambrian high-pressure 11n 'anıorphic rocks within the collision zone of the Yangtze and Cathaysia blocks, China * dr te/glaucophane-type facies. International Geological Review 38, 87-93. doi.org/10.1( 80/0 )206819709465326

Zhou, J.B., Wilde, S.A., Zhang, X.Z., Zhao, G.C., Zheng, C., Wang, Y.J., Zhang, X.H., 2009. The onset of Pacific margin accretion in NE China: Evi ence from the Heilongiiang high-pressure metamorphic belt. Tectonophysics 478, 230-246.

Zhou, J. C., \& Chen, R., 2001. Geochemistry c 1 ttc Mesozoic interaction between crust and mantle in southeastern Fujian Province. Gt chemistry 30(6), 547-558.

Zhou, J. C., Jiang, S. Y., Wang, X. K., ang, J. H., \& Zhang, M. Q., 2006. Study on lithogeochemistry of Middle Jurassic :asalts from southern China represented by the Fankeng basalts from Yongding of 1 iian Province. Science in China: Earth Sciences 49(10), 1020-1031. doi.org/10.1007/s1 4? J- ^J6-1020-2

Zhou, M. F., Yan, D. P., Kenn dy, A., Li, Y. Q., \& Ding, J., 2002. SHRIMP U-Pb zircon geochronological and ger. he, ical evidence for Neoproterozoic arc magmatism along the western margin of the Ya-otze Block, South China. Earth and Planetary Science Letter 196, 51-67. doi.org/10.1016 $\approx$ nr, 12-821X(01)00595-7

Zhou, X. M., \& Li W. X., :000. Origin of Late mesozoic igneous rocks in Southeastrn China: implications for liı osphere subduction and underplating of mafic magmas. Tectonophysics 326, 269-287. dol.org/10.1016/S0040-1951(00)00120-7

Zhou, X. M., Sun, T, Shen,W. Z., Shu, L. S., \& Niu, Y. L., 2006. Petrogenesis of Mesozoic granitoids and volcanicrocks in South China: A response to tectonic evolution. Episodes 29(1), 26-33. doi.org/10.1007/s00254-006-0175-7

Zhou, Z. Y., \& Dean, W. T., 1996. Phanerozoic geology of Northwest China. Beijing: Science Press, 251p. (in Chinese with English abstract)

\section{Figure captions}

\section{Fig. 1 Simplified tectonic framework map of the South China Block}

1, Dongxiang-Dexing-Shexian Neoproterzoic fault zone; 2, Songma-Ailaoshan-Jinshajiang early Mesozoic suture zone. 
Fig. 2 Simplified regional geological map of South China

1, Shaoxing-Pingxiang-Longsheng fault zone; 2, Zhenghe-Dapu fault zone; 3, Dongxiang-Dexing-Shexian fault zone; 4, Ganjiang fault zone; 5, Miluo-Xiangtan fault zone; 6, Jishou-Longsheng fault zone; 7, Shitai-Jiujiang-Jishou buried fault zone; 8, Sihui-Yangchun-Wuchuan fault zone; 9, Tan-Lu fault zone.

Fig. 3 Distribution map of Neoproterozoic igneous rocks and their isotopic ages in the Jiangnan Orogenic Belt. Reference data can be found in Table S1.

Fig. 4 A comparison of crystallization ages of Neoprotem zo: : igneous suites from various units of South China. Reference data cr... he sound in Table S1.

Fig. 5 The distribution map of the well-expos $+N$ :oproterozoic unconformity in the Jiangnan Orogenic Belt

Abbreviations for names of provinces: $\mathrm{AH}^{\mathrm{r}}, \mathrm{An}^{\mathrm{n}}$ ai; FJ, Fujian; GD, Guangdong; GX, Guangxi; GZ, Guizhou; HB, Hube', I'N, Hunan; JS, Jiangsu; JX, Jiangxi; YN, Yunnan; ZJ, Zhejiang.

Fig. 6 Field-photographs of th $\cdot r$-exposed Neoproterozoic unconformity in the Jiangnan Orogenic Bel $c$ (lc ated in Fig. 5)

Notes: 1, Lantian of Xiu. ing County (Southern Anhui); 2, Renjiapu of Xiushui County (Northern Jiangxi); ., Yunxi of Linxiang City (Northern Hunan); 4, Madiyi of Yuanling County (W :ste. $\eta$ Hunan); 5, Sibao of Luocheng County (Northern Guangxi); 6, Fangjingshan ot ' 'iangkou County (Eastern Guizhou). Pt 3 lk, Likou Group; $\mathrm{Pt}_{3} s x$, Shangxi Group; $\mathrm{Pt}_{3 \text { ss }}$, Upper Shuangqiaoshan Group; $\mathrm{Pt}_{3} x$, Lower Shuangqiaoshan Group; $\mathrm{Pt}_{3} b x$, Banxi Group; $\mathrm{Pt}_{3} l j$, Lengjiaxi Group; $\mathrm{Pt}_{3} d$, Danzhou Formation; $\mathrm{Pt}_{3} s b$, Sibao Group; $\mathrm{Pt}_{3} x j$, Xiajiang Group; $\mathrm{Pt}_{3} f j$, Fanjingshan Group.

Fig. 7 Distribution map of the Upper Tonian to lower Paleozoic strata and of the early Paleozoic granitoids with isotopic data

1, Shaoxing-Pingxiang-Longsheng fault zone; 2, Zhenghe-Dapu fault zone; 3, Dongxiang-Dexing- Shexian fault zone; 4, Nanchang-Wenjiashi fault zone; The number in bracket of dating value indicates the isotopic dating method: 1, SHRIMP 
zircon U-Pb; 2, SIMS zircon U-Pb; 3, LA-ICPMS zircon U-Pb.

Fig. 8 Neoproterozoic lithospheric dynamic evolution model of the South China Block (non-scale for thicknesses of continental crust and lithosphere)

Fig. 9 Comparisons of the Paleozoic sedimentary rock assemblages and of the depositional environments for the lower Yangtze, the Jiangnan and the southeast China regions

Fig. 10 Comparisons of the lower Paleozoic stratigra shic sequences in the nine segments in South China

Fig. 11 Field-photographs for the lower Paleozoic sidimentary rocks and structures, indicating a coastal-nerit cos thyal depositional environment of South China

A. Lower Cambrian sandy and mud ' $v$ f ysch rocks; B. Ripple mark in the Lower Cambrian sandstone; C. Flute cast in . he Upper Cambrian sandstone; D. Lenticular mudstone blocks in ths Upper Cambrian sandstone layer; E. Cross-bedding in the Middle Cro uvician sandstone; F. Big quartz sandstone block wrapped by the Upper Or 1ov: ian mudstone; G. Upper Cambrian feldspar sandstone with oblique reduing; H. Intercalated limestone layers in the Lower Cambrian sandstone. L, linestone; M, mudstone; S, Sandstone; QS, quartz sandstone.

Fig. 12 A compariso of crystallization ages of the early Paleozoic igneous suites and ages of coeval ductile deformation in the Cathaysia and Yangtze regions. Reference data can be found in Table $\mathrm{S} 2$.

Fig. 13 Tectonic and paleogeographic reconstruction of the South China Block from the late Neoproterozoic to the Middle Triassic (modified from Yu JH et al., 2008; Xu et al., 2016, Zhao GC et al., 2018 and Shu LS et al., 2019). Abbreviations for microcontinental blocks: Al, Alax; Ca, Cathaysia; C-Qil, Central Qilian; IC, Indochina; NC, North China; N-Qt, North Qiangtang; Qai, Qaidam; SC, South China; Sbms, Sibumasu; S-Qt-Ls, South Qiangtang - Lhasa; Ta, Tarim; Yz, Yangtze.

Abbreviations for special tectonic units: JN, Jiangnan Orogenic Bbelt; NR, Nanhua 
rift basin; SM, Songma suture zone; SS, Shangdan suture zone; TS, Tianshan Orogenic Belt; WY, Wuyi-Yunkai Orogenic Belt; XF, Xuefeng Mountains; QZB, Qinzhou Bay.

Fig. 14 Upper Paleozoic to lower Mesozoic stratigraphic columns from Anhui, Zhejiang, Jiangxi, Fujian provinces of Southeast China, reflecting their sedimentary environments

Fig. 15 A comparison of crystallization ages of the early Mesozoic granitoids and ages of coeval ductile deformation in the Cathaysia and Jiangnan regions. Reference data are listed in Table S3.

Fig. 16 Simplified geological map of the Southea $+C$ nina region, showing the distribution of Mesozoic-Cenozoic basins anc granitic plutons

1, Shaoxing-Pingxiang-Longsheng fault zone; L, L’ongxiang-Dexing-Shexian fault zone; 3. Zhenghe-Dapu fault zone; Ganjiang River fault zone; 5, Sihui-Yangchun-Wuchuan fault zc ne: 6, Wuzhou-Sihui buried fault zone; 7, Chalin-Guangchang buried faı ${ }^{1 t}$ zone; 8, Changle-Nanao fault zone; 9, Chenzhou-Linwu fault zone.

Fig. 17 Geological s'ctic .I traversing the Late Mesozoic Southeast China magmatic c $>m_{1}$ lex zone

Fig. 18 Field-photographs of lower Paleozoic sedimentary rocks from the Jiangnan (A-C) and Cathaysia (D-F) regions

A, Middle Ordovician limestome (Chalin of Quanzhou City); B, Lower Cambrian graphitic bearing material layers (10 km North of Qidong County); C, Lower Cambrian carbonaceous rock (Shuiche of Guanyang County); D, Cambrian sandy-muddy slate (20 km South of Qidong County); E, Lower Cambrian carbonaceous slate (12 km West of Nankang City), F, Middle Ordovician sandy slate 
and muddy phyllite (Chalin of Quanzhou City)

Table captions

Table S1 Summary of ages and isotopic ratios for the Neoproterozoic magmatic rocks in South China

Table S2 Summary of ages and isotopic ratios for the Early Paleozoic magmatic rocks from Jiangnan and Cathaysia regions

Table S3 Summary of ages and isotopic ratios for tl e E: rly Mesozoic magmatic rocks from Jiangnan and Cathaysia regior:

Table 1 Comparison of geological featur so 0 the Early Paleozoic South China intracontinental orogen with tynica' subduction-collision-type orogenic belts

\section{Declaration of interests}

The authors declare that they hav no known competing financial interests or personal relationships that could have app - a ${ }^{*}$ a io influence the work reported in this paper. 